\title{
SYNTHESIS OF FUSED POLYCYCLES BY 1,4-PALLADIUM MIGRATION CHEMISTRY
}

\author{
Qinhua Huang, Marino A. Campo, Tuanli Yao, Qingping Tian and Richard C. Larock* \\ Department of Chemistry, Iowa State University, Ames, IA 50011 \\ larock@iastate.edu
}

\section{Table of Contents}

$\begin{array}{lll}\text { 1. General procedures } & \text { S2 }\end{array}$

$\begin{array}{ll}\text { 2. Preparation of starting materials } & \text { S2 - S27 }\end{array}$

3. Representative procedure for the palladium-catalyzed migration reactions $\quad$ S27

4. Characterization of migration products $\quad$ S27 - S34

5. References $\quad$ S35

6. $\quad{ }^{1} \mathrm{H}$ NMR and ${ }^{13} \mathrm{C}$ NMR spectra of starting materials $\quad$ S36 - S81

7. ${ }^{1} \mathrm{H}$ NMR and ${ }^{13} \mathrm{C}$ NMR spectra of migration products $\quad \mathrm{S} 82-\mathrm{S} 107$ 
General procedures. All ${ }^{1} \mathrm{H}$ and ${ }^{13} \mathrm{C}$ NMR spectra were recorded at 300 and $75.5 \mathrm{MHz}$ or 400 and $100 \mathrm{MHz}$ respectively. Thin-layer chromatography was performed using commercially prepared 60-mesh silica gel plates (Whatman K6F), and visualization was effected with short wavelength UV light $(254 \mathrm{~nm})$ and/or a basic $\mathrm{KMnO}_{4}$ solution [3 $\mathrm{g}$ of $\mathrm{KMnO}_{4}+20 \mathrm{~g}$ of $\mathrm{K}_{2} \mathrm{CO}_{3}+5 \mathrm{~mL}$ of $\mathrm{NaOH}(5 \%)+300 \mathrm{~mL}$ of $\left.\mathrm{H}_{2} \mathrm{O}\right]$. All melting points are uncorrected. High resolution mass spectra were recorded on a Kratos MS50TC double focusing magnetic sector mass spectrometer using EI at $70 \mathrm{eV}$. Compounds 19, ${ }^{1} \mathbf{2 0},{ }^{1} \mathbf{3 6},{ }^{1}$ and $49^{1}$ were prepared according to literature procedures.

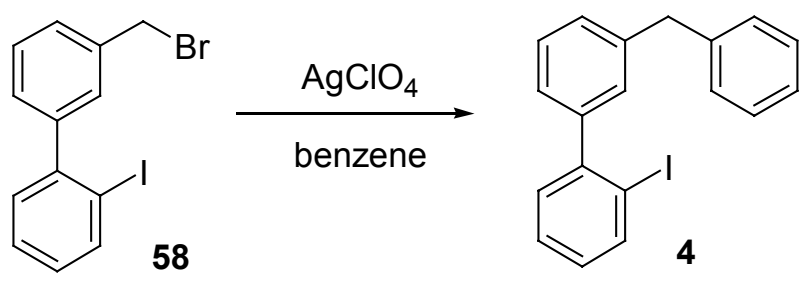

3'-Benzyl-2-iodobiphenyl (4). This biphenyl was prepared from 3'-bromomethyl-2iodobiphenyl (58) ${ }^{1}$ by following a procedure from the literature. ${ }^{2}$ To a suspension of $\mathrm{AgClO}_{4}$ $(0.28 \mathrm{~g}, 1.4 \mathrm{mmol})$ in benzene $(4.0 \mathrm{~mL})$ was added compound $\mathbf{5 8}(0.261 \mathrm{~g}, 0.7 \mathrm{mmol})$ in benzene $(4.0 \mathrm{~mL})$ and the resulting mixture was stirred overnight at room temperature in the dark. The reaction mixture was diluted with diethyl ether $(50 \mathrm{~mL})$, filtered and washed with brine $(25 \mathrm{~mL})$. The organic layer was dried $\left(\mathrm{Na}_{2} \mathrm{SO}_{4}\right)$, filtered and the solvent evaporated under reduced pressure. The residue was purified by silica gel column chromatography using 50:1 hexane/EtOAc to afford $0.187 \mathrm{~g}(72 \%)$ of the indicated compound 4 as a colorless oil: ${ }^{1} \mathrm{H}$ NMR $\left(\mathrm{CDCl}_{3}\right) \delta 4.03(\mathrm{~s}, 3 \mathrm{H}), 6.97-7.01(\mathrm{~m}, 1 \mathrm{H}), 7.15-7.34(\mathrm{~m}, 11 \mathrm{H}), 7.92(\mathrm{dd}, J=1.0$, $8.0 \mathrm{~Hz}, 1 \mathrm{H}) ;{ }^{13} \mathrm{C} \mathrm{NMR}\left(\mathrm{CDCl}_{3}\right) \delta 42.0,98.8,126.2,127.1,128.2,128.2,128.3,128.6,128.8$, 
129.1, 130.1, 130.2, 139.6, 140.8, 141.0, 144.3, 146.6; IR $\left(\mathrm{CH}_{2} \mathrm{Cl}_{2}\right) 3056,3025,2917,1601$, 1583, 1494, $1461 \mathrm{~cm}^{-1}$; HRMS m/z 370.0224 (calcd for $\mathrm{C}_{19} \mathrm{H}_{15} \mathrm{I}, 370.0218$ ).

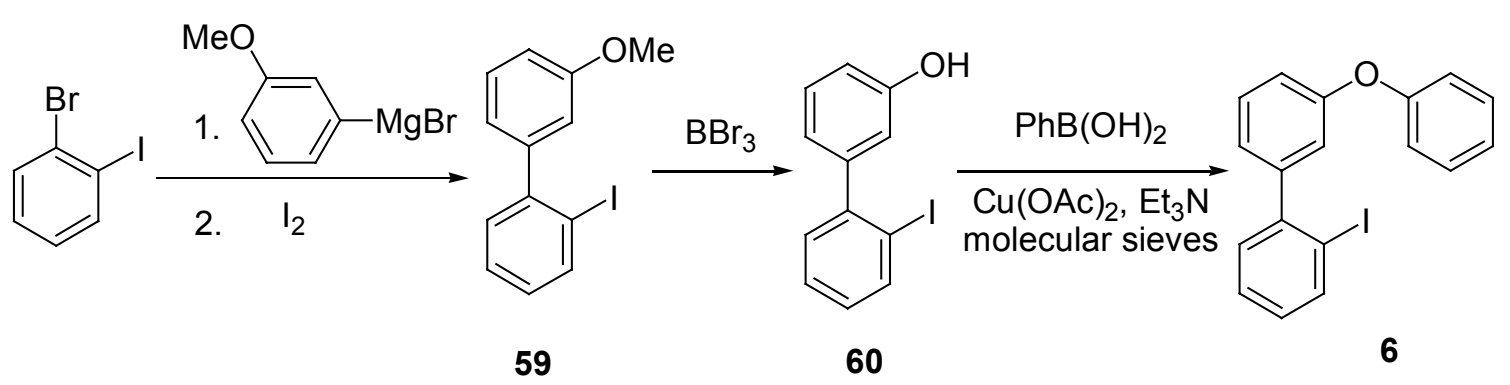

2-Iodo-3'-methoxybiphenyl (59). Compound 59 was prepared by a procedure reported by Hart $e t$ al. $^{3}$ A solution of 2-bromoiodobenzene $(1.415 \mathrm{~g}, 5.0 \mathrm{mmol})$ in THF $(10 \mathrm{~mL})$ was added slowly $(90 \mathrm{~min})$ to a solution of 3-methoxyphenylmagnesium bromide [prepared from 3-bromoanisole (1.87 g, $10 \mathrm{mmol})$ and $\mathrm{Mg}(0.246 \mathrm{~g}, 10 \mathrm{mmol})$ in THF $(30 \mathrm{~mL})]$, and the mixture was stirred under Ar for an additional $14 \mathrm{~h}$ at room temperature. The reaction was quenched by adding $\mathrm{I}_{2}(3.8 \mathrm{~g}, 15 \mathrm{mmol})$, and the mixture was stirred for an additional $30 \mathrm{~min}$ at room temperature. The excess $\mathrm{I}_{2}$ was destroyed by adding $10 \%$ aq $\mathrm{NaHSO}_{3}(35 \mathrm{~mL})$ and the organic layer was separated and washed with brine $(20 \mathrm{~mL})$. Finally, the organic layer was dried $\left(\mathrm{MgSO}_{4}\right)$, filtered, and the solvent removed under reduced pressure. The residue was chromatographed using 30:1 hexane/EtOAc to afford $0.620 \mathrm{~g} \mathrm{(40 \% )} \mathrm{of} \mathrm{the} \mathrm{desired}$ compound 59 as a clear oil: ${ }^{1} \mathrm{H}$ NMR $\left(\mathrm{CDCl}_{3}\right) \delta 3.84(\mathrm{~s}, 3 \mathrm{H})$, 6.88-6.95 (m, 3H), 7.01-7.05 (m, 1H), 7.29-7.38 (m, 3H), $7.95(\mathrm{dd}, J=1.2,8.0 \mathrm{~Hz}, 1 \mathrm{H}) ;{ }^{13} \mathrm{C} \mathrm{NMR}\left(\mathrm{CDCl}_{3}\right) \delta$ 55.4, 98.5, 113.4, 115.0, 121.8, 128.1, 128.9, 129.1, 130.1, 139.6, 145.5, 146.5, 159.1; HRMS m/z 309.9859 (calcd for $\mathrm{C}_{13} \mathrm{H}_{11} \mathrm{IO}, 309.9855$ ).

2-Iodo-3'-phenoxybiphenyl (6). This biphenyl was prepared in two steps from 2-iodo3-methoxybiphenyl (59). To a solution of compound 59 (0.97 g, $3.14 \mathrm{mmol})$ in $\mathrm{CH}_{2} \mathrm{Cl}_{2}(20$ 
$\mathrm{mL}$ ) at $-78{ }^{\circ} \mathrm{C}$ was added $1.0 \mathrm{M} \mathrm{BBr}_{3}$ in $\mathrm{CH}_{2} \mathrm{Cl}_{2}(4.1 \mathrm{~mL}, 4.1 \mathrm{mmol})$. The resulting solution was allowed to warm to room temperature and stirred for $2 \mathrm{~h}$. The mixture was worked up with ice $(15 \mathrm{~g})$ and extracted with diethyl ether $(75 \mathrm{~mL})$. The organic layer was dried $\left(\mathrm{Na}_{2} \mathrm{SO}_{4}\right)$, filtered and the solvent evaporated under reduced pressure. The residue was purified by silica gel column chromatography using 3:1 hexane/EtOAc to afford $0.91 \mathrm{~g}$ (98 \%) of 3-(2-iodophenyl)phenol (60) as a clear oil: ${ }^{1} \mathrm{H}$ NMR $\left(\mathrm{CDCl}_{3}\right) \delta 5.04$ (br s, $\left.1 \mathrm{H}\right), 6.80$ $6.81(\mathrm{~m}, 1 \mathrm{H}), 6.85-6.90(\mathrm{~m}, 2 \mathrm{H}), 7.00-7.05(\mathrm{~m}, 1 \mathrm{H}), 7.25-7.31(\mathrm{~m}, 2 \mathrm{H}), 7.37(\mathrm{dt}, J=0.8,7.6$ $\mathrm{Hz}, 1 \mathrm{H}), 7.94(\mathrm{dd}, J=0.8,8.0 \mathrm{~Hz}, 1 \mathrm{H}) ;{ }^{13} \mathrm{C} \mathrm{NMR}\left(\mathrm{CDCl}_{3}\right) \delta 98.4,114.7,116.4,122.0,128.1$, 128.9, 129.3 130.0, 139.5, 145.8, 146.2, 155.0. 3-(2-Iodophenyl)phenol (60) was phenylated by a literature procedure. ${ }^{4}$ A suspension of 3-(2-iodophenyl)phenol $(0.222 \mathrm{~g}, 0.75 \mathrm{mmol})$, phenylboronic acid (0.183 g, $1.5 \mathrm{mmol}), \mathrm{Cu}(\mathrm{OAc})_{2}(0.163 \mathrm{~g}, 0.90 \mathrm{mmol}), \mathrm{Et}_{3} \mathrm{~N}(0.38 \mathrm{~g}, 3.75$ mmol), and 5 Angstrom molecular sieves $(0.2 \mathrm{~g})$ in $\mathrm{CH}_{2} \mathrm{Cl}_{2}(6.0 \mathrm{~mL})$ was stirred under $\mathrm{O}_{2}(1$ atm) for $2 \mathrm{~d}$ at room temperature. The reaction mixture was diluted with diethyl ether (50 $\mathrm{mL}$ ), filtered, and the solvent evaporated under reduced pressure. The residue was purified by silica gel column chromatography using 15:1 hexane/EtOAc to afford $0.129 \mathrm{~g} \mathrm{(46 \% )} \mathrm{of}$ the indicated compound 6 as a clear oil: ${ }^{1} \mathrm{H}$ NMR $\left(\mathrm{CDCl}_{3}\right) \delta$ 7.00-7.12 (m, 7H), 7.25-7.40 (m, 5H), $7.92(\mathrm{dd}, J=1.2,8.0 \mathrm{~Hz}, 1 \mathrm{H}) ;{ }^{13} \mathrm{C} \mathrm{NMR}\left(\mathrm{CDCl}_{3}\right) \delta 98.4,118.2,119.1,119.8,123.4$, $124.2,128.2,129.0,129.4,129.8,130.0,139.6,145.9,146.0,156.8,157.1 ; \mathrm{IR}\left(\mathrm{CH}_{2} \mathrm{Cl}_{2}\right) 3058$, $1578,1488,1460,1222, \mathrm{~cm}^{-1}$; HRMS $m / z 372.0020$ (calcd for $\mathrm{C}_{18} \mathrm{H}_{13} \mathrm{IO}, 372.0011$ ). 
<smiles>Oc1cccc(-c2ccccc2I)c1</smiles>

60

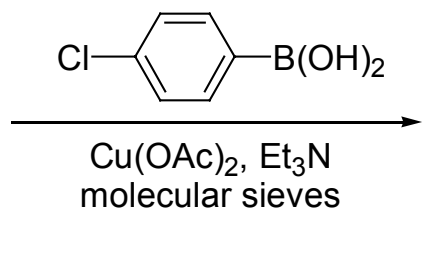

$\mathrm{Cu}(\mathrm{OAc})_{2}, \mathrm{Et}_{3} \mathrm{~N}$
molecular sieves<smiles>Clc1ccc(Oc2cccc(-c3ccccc3I)c2)cc1</smiles>

8

2-Iodo-3'-(p-chlorophenoxy)biphenyl (8). This biphenyl was prepared by a procedure similar to that used for compound 6. A suspension of 3-(2-iodophenyl)phenol (60) (0.222 g, $0.75 \mathrm{mmol}), p$-chlorophenylboronic acid $(0.235 \mathrm{~g}, 1.5 \mathrm{mmol}), \mathrm{Cu}(\mathrm{OAc})_{2}(0.163 \mathrm{~g}, 0.90$ $\mathrm{mmol}), \mathrm{Et}_{3} \mathrm{~N}(0.38 \mathrm{~g}, 3.75 \mathrm{mmol})$, and 5 Angstrom molecular sieves $(0.2 \mathrm{~g})$ in $\mathrm{CH}_{2} \mathrm{Cl}_{2}(6.0$ $\mathrm{mL}$ ) was stirred under $\mathrm{O}_{2}(1 \mathrm{~atm})$ for $2 \mathrm{~d}$ at room temperature. The reaction mixture was diluted with diethyl ether $(50 \mathrm{~mL})$, filtered, and the solvent evaporated under reduced pressure. The residue was purified by chromatography on a silica gel column using 30:1 hexanes/ethyl acetate to afford $79.5 \mathrm{mg}(26 \%)$ of the indicated compound $\mathbf{8}$ as a clear oil: ${ }^{1} \mathrm{H}$ NMR $\left(\mathrm{CDCl}_{3}\right) \delta$ 6.96-7.09 (m, 6H), 7.27-7.41 (m, 5H), $7.93(\mathrm{~d}, J=8.0 \mathrm{~Hz}, 1 \mathrm{H}) ;{ }^{13} \mathrm{C}$ $\operatorname{NMR}\left(\mathrm{CDCl}_{3}\right) \delta 98.4,118.2,119.9,120.3,124.6,128.2,128.4,129.1,129.6,129.8,130.0$, 139.6, 145.8, 146.0, 155.8, 156.4; IR $\left(\mathrm{CH}_{2} \mathrm{Cl}_{2}\right) 3057,1576,1484,1460,1228 \mathrm{~cm}^{-1}$; HRMS $m / z 405.9632$ (calcd for $\mathrm{C}_{18} \mathrm{H}_{12} \mathrm{IClO}, 405.9621$ ).<smiles>BrCc1cccc(-c2ccccc2I)c1</smiles><smiles>c1ccc2[nH]ccc2c1</smiles>

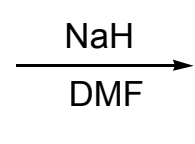<smiles>Ic1ccccc1-c1cccc(Cn2ccc3ccccc32)c1</smiles>

1-[3-(2-Iodophenyl)benzyl]indole (10). To a suspension of $\mathrm{NaH}(0.031 \mathrm{~g}, 1.30 \mathrm{mmol})$ in DMF $(2 \mathrm{~mL})$ at $0{ }^{0} \mathrm{C}$ was added $1 H$-indole $(0.117 \mathrm{~g}, 1.0 \mathrm{mmol})$ in DMF $(3 \mathrm{~mL})$ and the 
mixture was stirred at room temperature for $30 \mathrm{~min}$. At this point 3'-bromomethyl-2iodobiphenyl (58) ${ }^{1}(0.347 \mathrm{~g}, 0.93 \mathrm{mmol})$ in DMF $(3 \mathrm{~mL})$ was added and the reaction mixture was stirred at $50{ }^{\circ} \mathrm{C}$ for $3 \mathrm{~h}$. The reaction mixture was diluted with diethyl ether $(50 \mathrm{~mL})$ and washed with brine $(60 \mathrm{~mL})$. The aqueous layer was reextracted with diethyl ether $(15 \mathrm{~mL})$ and the organic layers were combined, dried $\left(\mathrm{MgSO}_{4}\right)$, and the solvent evaporated under reduced pressure. The residue was purified by column chromatography using 12:1 hexanes/ethyl acetate to afford $0.335 \mathrm{~g}(88 \%)$ of the desired compound $\mathbf{1 0}$ as a clear oil: ${ }^{1} \mathrm{H}$ $\operatorname{NMR}\left(\mathrm{CDCl}_{3}\right) \delta 5.34(\mathrm{~s}, 2 \mathrm{H}), 6.54(\mathrm{~d}, J=2.8 \mathrm{~Hz}, 1 \mathrm{H}), 6.98(\mathrm{td}, J=7.6,1.6 \mathrm{~Hz}, 1 \mathrm{H}), 7.09-$ $7.23(\mathrm{~m}, 7 \mathrm{H}), 7.30-7.34(\mathrm{~m}, 3 \mathrm{H}), 7.64(\mathrm{~d}, J=7.6 \mathrm{~Hz}, 1 \mathrm{H}), 7.90(\mathrm{dd}, J=8.0,0.8 \mathrm{~Hz}, 1 \mathrm{H}) ;{ }^{13} \mathrm{C}$ $\operatorname{NMR}\left(\mathrm{CDCl}_{3}\right) \delta 50.1,98.6,101.9,109.9,119.6,121.1,121.8,126.2,128.0,128.2,128.4$, 128.6, 128.6, 128.9, 129.0, 130.1, 136.4, 137.4, 139.6, 144.6, 146.1; IR $\left(\mathrm{CH}_{2} \mathrm{Cl}_{2}\right)$ 3052, 2972, 2922, 2863, 1462, 1437, $1316 \mathrm{~cm}^{-1}$; HRMS m/z 409.0334 (calcd for $\mathrm{C}_{21} \mathrm{H}_{16} \mathrm{IN}, 409.0328$ ).

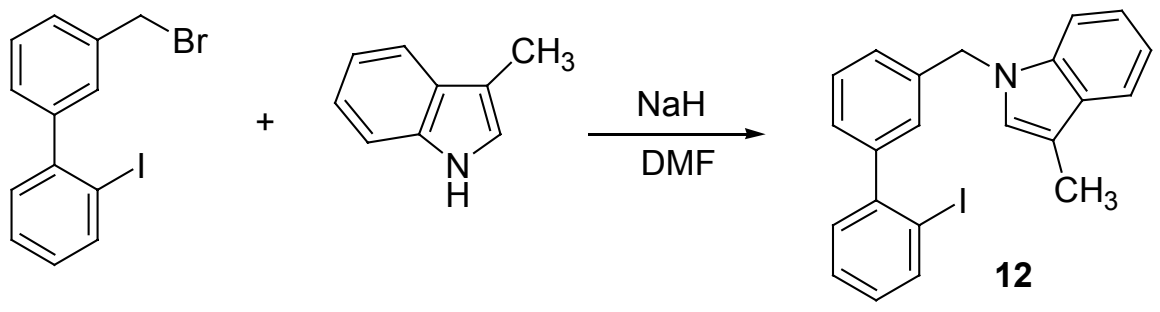

1-[3-(2-Iodophenyl)benzyl]-3-methylindole (12). To a suspension of $\mathrm{NaH}(0.031 \mathrm{~g}$, $1.30 \mathrm{mmol})$ in DMF $(2 \mathrm{~mL})$ at $0{ }^{0} \mathrm{C}$ was added 3-methyl- $1 H$-indole $(0.131 \mathrm{~g}, 1.0 \mathrm{mmol})$ in DMF (3 mL) and the mixture was stirred at room temperature for $30 \mathrm{~min}$. At this point 3'bromomethyl-2-iodobiphenyl (58) ${ }^{1}(0.347 \mathrm{~g}, 0.93 \mathrm{mmol})$ in DMF $(3 \mathrm{~mL})$ was added and the reaction mixture was stirred at $50{ }^{\circ} \mathrm{C}$ for $3 \mathrm{~h}$. The reaction mixture was diluted with diethyl ether $(50 \mathrm{~mL})$ and washed with brine $(60 \mathrm{~mL})$. The aqueous layer was reextracted with 
diethyl ether $(15 \mathrm{~mL})$ and the organic layers were combined, dried $\left(\mathrm{MgSO}_{4}\right)$, and the solvent evaporated under reduced pressure. The residue was purified by column chromatography using 12:1 hexanes/ethyl acetate to afford $0.362 \mathrm{~g} \mathrm{(92 \% )} \mathrm{of} \mathrm{the} \mathrm{desired} \mathrm{compound} \mathbf{1 2}$ as a clear oil: ${ }^{1} \mathrm{H}$ NMR $\left(\mathrm{CDCl}_{3}\right) \delta 2.33(\mathrm{~d}, J=0.8 \mathrm{~Hz}, 3 \mathrm{H}), 5.29(\mathrm{~s}, 2 \mathrm{H}), 6.92-6.92(\mathrm{~m}, 1 \mathrm{H}), 6.97-$ $6.99(\mathrm{~m}, 1 \mathrm{H}), 7.10-7.24(\mathrm{~m}, 6 \mathrm{H}), 7.27-7.34(\mathrm{~m}, 3 \mathrm{H}), 7.56-7.58(\mathrm{~m}, 1 \mathrm{H})$, 7.90-7.92 (m, 1H); ${ }^{13} \mathrm{C}$ NMR $\left(\mathrm{CDCl}_{3}\right) \delta 10.1,50.1,98.8,109.9,111.2,119.1,119.3,121.9,126.2,126.4,128.2$, $128.4,128.7,128.7,129.2,129.3,130.3,136.9,137.9,139.8,144.7,146.4 ; \mathrm{IR}\left(\mathrm{CH}_{2} \mathrm{Cl}_{2}\right)$ 3052, 2914, 1611, 1465, 1330, $1012 \mathrm{~cm}^{-1}$; HRMS m/z 423.0491 (calcd for $\mathrm{C}_{22} \mathrm{H}_{18} \mathrm{IN}$, 423.0484).<smiles>BrCc1cccc(-c2ccccc2I)c1</smiles><smiles>Oc1ccccc1</smiles><smiles>Ic1ccccc1-c1cccc(COc2ccccc2)c1</smiles>

3-(2-Iodophenyl)benzyl phenyl ether (14). To a suspension of $\mathrm{NaH}$ (0.031 g, 1.30 mmol) in DMF $(2 \mathrm{~mL})$ at $0{ }^{0} \mathrm{C}$ was added phenol $(0.094 \mathrm{~g}, 1.0 \mathrm{mmol})$ in DMF $(3 \mathrm{~mL})$ and the mixture was stirred at room temperature for $30 \mathrm{~min}$. At this point, 3'-bromomethyl-2iodobiphenyl (58) ${ }^{1}(0.347 \mathrm{~g}, 0.93 \mathrm{mmol})$ in DMF $(3 \mathrm{~mL})$ was added and the reaction mixture was stirred at room temperature for $3 \mathrm{~h}$. The reaction mixture was diluted with diethyl ether $(50 \mathrm{~mL})$ and washed with brine $(60 \mathrm{~mL})$. The aqueous layer was reextracted with diethyl ether $(15 \mathrm{~mL})$ and the organic layers were combined, dried $\left(\mathrm{MgSO}_{4}\right)$, and the solvent evaporated under reduced pressure. The residue was purified by column chromatography using 12:1 hexanes/ethyl acetate to afford $0.359 \mathrm{~g}(100 \%)$ of the desired compound $\mathbf{1 4}$ as a 
clear oil: ${ }^{1} \mathrm{H}$ NMR $\left(\mathrm{CDCl}_{3}\right) \delta 5.13(\mathrm{~s}, 2 \mathrm{H}), 6.96-7.04(\mathrm{~m}, 4 \mathrm{H})$, 7.26-7.33 (m, 4H), 7.39-7.46 (m, 4H), 7.94-7.96 (m, 1H); ${ }^{13} \mathrm{C}$ NMR $\left(\mathrm{CDCl}_{3}\right) \delta 69.9,98.6,115.0,121.1,126.8,128.3$, $128.4,128.5,129.0,129.0,129.6,130.2,137.0,139.6,144.5,146.4,158.8 ; \mathrm{IR}\left(\mathrm{CH}_{2} \mathrm{Cl}_{2}\right)$ 3056, 2919, 1598, 1494, $1238 \mathrm{~cm}^{-1}$; HRMS $m / z 386.0172$ (calcd for $\mathrm{C}_{19} \mathrm{H}_{15} \mathrm{IO}, 386.0168$ ).

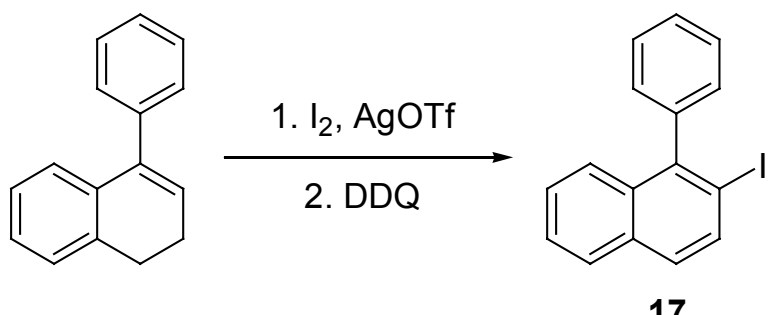

2-Iodo-1-phenylnaphthalene (17). To a solution of 3,4-dihydro-1-phenylnaphthalene $(1.30 \mathrm{~g}, 6.3 \mathrm{mmol})$ and $\mathrm{I}_{2}(2.24 \mathrm{~g}, 8.8 \mathrm{mmol})$ in anhydrous $\mathrm{CH}_{3} \mathrm{CN}(15 \mathrm{~mL})$ was added dropwise $\operatorname{AgOTf}(1.75 \mathrm{~g}, 6.8 \mathrm{mmol})$ in anhydrous $\mathrm{CH}_{3} \mathrm{CN}(20 \mathrm{~mL})$. The resulting mixture was stirred at room temperature in the dark for $1 \mathrm{~h}$. The reaction was diluted with diethyl ether $(70 \mathrm{~mL})$ and washed with satd aq $\mathrm{Na}_{2} \mathrm{~S}_{2} \mathrm{O}_{3}(25 \mathrm{~mL})$. The organic layer was dried $\left(\mathrm{Na}_{2} \mathrm{SO}_{4}\right)$, filtered and the solvent removed under reduced pressure. The residue was dissolved in benzene $(25 \mathrm{~mL})$. To this solution was added DDQ (2.86 g, $12.6 \mathrm{mmol})$ and the reaction was heated at $65{ }^{\circ} \mathrm{C}$ for $2 \mathrm{~d}$. The resulting mixture was filtered and washed with 10 $\%$ aq $\mathrm{Na}_{2} \mathrm{CO}_{3}(25 \mathrm{~mL})$. The organic layer was filtered, dried $\left(\mathrm{Na}_{2} \mathrm{SO}_{4}\right)$ and the solvent removed under reduced pressure. The residue was purified by silica gel column chromatography using 50:1 hexane/EtOAc to afford $1.47 \mathrm{~g}(70 \%)$ of the indicated compound 17 as a clear oil: ${ }^{1} \mathrm{H} \mathrm{NMR}\left(\mathrm{CDCl}_{3}\right) \delta$ 7.22-7.26 (m, 2H), 7.32-7.34 (m, 1H), 7.38$7.56(\mathrm{~m}, 6 \mathrm{H}), 7.80-7.83(\mathrm{~m}, 1 \mathrm{H}), 7.95(\mathrm{~d}, J=8.7 \mathrm{~Hz}, 1 \mathrm{H}) ;{ }^{13} \mathrm{C} \mathrm{NMR}\left(\mathrm{CDCl}_{3}\right) \delta$ 98.7, 126.5, 127.0, 127.4, 128.1, 128.1, 128.7, 129.3, 130.2, 133.1, 133.6, 135.8, 143.5, 144.7; IR 
$\left(\mathrm{CH}_{2} \mathrm{Cl}_{2}\right)$ 3053, 1577, 1502, 1442, 1382, $1306 \mathrm{~cm}^{-1}$; HRMS m/z 329.9910 (calcd for $\mathrm{C}_{16} \mathrm{H}_{11} \mathrm{I}$, 329.9906).
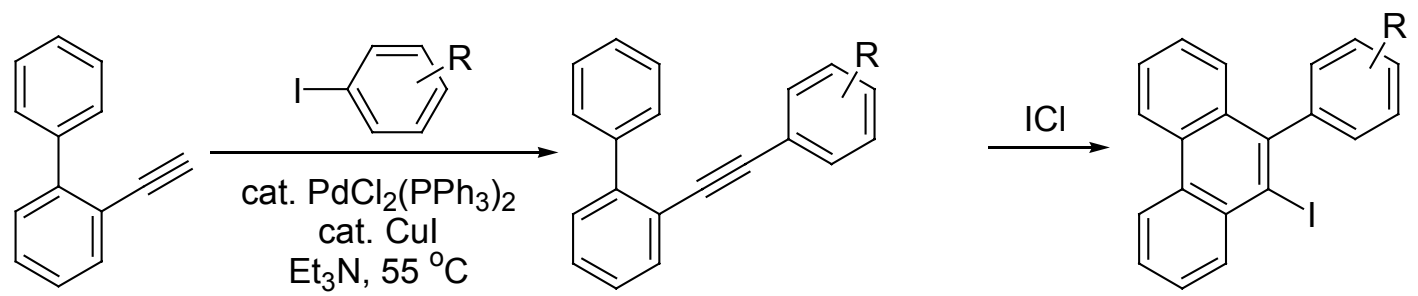

General procedure for preparation of the 2-(arylethynyl)biphenyls. To a solution of the corresponding aryl iodide $(1.0 \mathrm{mmol})$ and the terminal alkyne $(1.2 \mathrm{mmol}, 1.2$ equiv $)$ in $\mathrm{Et}_{3} \mathrm{~N}(4.0 \mathrm{~mL})$ were added $\mathrm{PdCl}_{2}\left(\mathrm{PPh}_{3}\right)_{2}(1.4 \mathrm{mg}, 2 \mathrm{~mol} \%)$ and $\mathrm{CuI}(2.0 \mathrm{mg}, 1 \mathrm{~mol} \%)$. The resulting mixture was then heated under an $\mathrm{N}_{2}$ atmosphere at $55^{\circ} \mathrm{C}$ for $3 \mathrm{~h}$. The mixture was allowed to cool to room temperature, and the ammonium salt was removed by filtration. The solvent was removed under reduced pressure and the residue was purified by column chromatography on silica gel to afford the corresponding product.

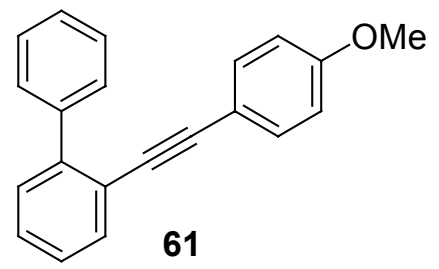

\section{2-[(4-Methoxyphenyl)ethynyl]biphenyl (61).2-}

Ethynylbiphenyl $1^{5}$ and 4-iodoanisole were employed. Purification by flash chromatography (30:1 hexane/EtOAc) afforded $0.21 \mathrm{~g}$ (74 \%) of the product as a clear liquid: ${ }^{1} \mathrm{H} \mathrm{NMR}\left(\mathrm{CDCl}_{3}\right) \delta 3.80$ (s, 3H), $6.84(\mathrm{dd}, J=2.4,6.9 \mathrm{~Hz}, 2 \mathrm{H}), 7.30(\mathrm{dd}, J=2.1,6.9 \mathrm{~Hz}, 2 \mathrm{H}), 7.34-7.50(\mathrm{~m}, 6 \mathrm{H})$, 7.64-7.73 (m, 3H); ${ }^{13} \mathrm{C} \mathrm{NMR}\left(\mathrm{CDCl}_{3}\right) \delta 55.5,88.4,92.5,114.2,115.9,122.2,127.3,127.6$, $128.1,128.4,129.6,129.7,132.9,133.1,140.9,143.9,159.8$.

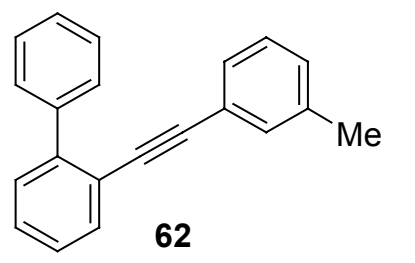

2-[(3-Methylphenyl)ethynyl]biphenyl (62). 2-Ethynylbiphenyl ${ }^{5}$ and 3-iodotoluene were employed. Purification by flash 
chromatography (40:1 hexane/EtOAc) afforded $0.26 \mathrm{~g}(95 \%)$ of the product as a clear liquid: ${ }^{1} \mathrm{H} \mathrm{NMR}\left(\mathrm{CDCl}_{3}\right) \delta 2.34(\mathrm{~s}, 3 \mathrm{H}), 7.12-7.22(\mathrm{~m}, 4 \mathrm{H}), 7.33-7.53(\mathrm{~m}, 6 \mathrm{H})$, 7.67-7.74 (m, 3H);

${ }^{13} \mathrm{C}$ NMR $\left(\mathrm{CDCl}_{3}\right) \delta 21.5,89.3,92.7,122.0,123.5,127.3,127.7,128.2,128.4,128.7,128.7$, $129.3,129.7,129.7,132.2,133.1,138.2,140.9,144.1$.

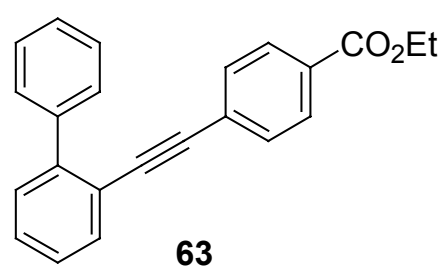

\section{Ethyl 4-(biphen-2-ylethynyl)benzoate (63). 2-}

Ethynylbiphenyl ${ }^{5}$ and ethyl 4-iodobenzoate were employed. Purification by flash chromatography (15:1 hexane/EtOAc) afforded $0.27 \mathrm{~g}(84 \%)$ of the product as a white solid: $\mathrm{mp}$ 58-60 ${ }^{\circ} \mathrm{C} ;{ }^{1} \mathrm{H} \mathrm{NMR}\left(\mathrm{CDCl}_{3}\right) \delta 1.38(\mathrm{t}, J=6.9 \mathrm{~Hz}, 3 \mathrm{H}), 4.36(\mathrm{q}, J=7.2 \mathrm{~Hz}, 2 \mathrm{H}), 7.32-7.48(\mathrm{~m}, 8 \mathrm{H})$, 7.64-7.66 (m, 3H), $7.96(\mathrm{~d}, J=8.4 \mathrm{~Hz}, 2 \mathrm{H}) ;{ }^{13} \mathrm{C} \mathrm{NMR}\left(\mathrm{CDCl}_{3}\right) \delta$ 14.6, 61.3, 91.7, 92.6, $121.3,127.4,127.9,128.2,128.3,129.3,129.63,129.64,129.8,129.9,131.4,133.2,140.6$, $144.5,166.3$.

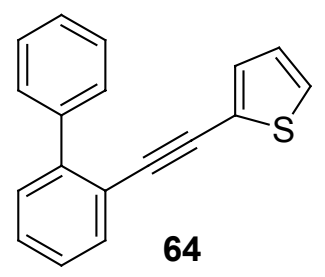

2-(Biphen-2-ylethynyl)thiophene (64). 2-Ethynylbiphenyl ${ }^{5}$ and 2iodothiophene were employed. Purification by flash chromatography (15:1 hexane/EtOAc) afforded $0.22 \mathrm{~g}(85 \%)$ of the product as a light yellow liquid: ${ }^{1} \mathrm{H}$ NMR $\left(\mathrm{CDCl}_{3}\right) \delta$ 6.98-7.00 (m, 1H), 7.15-7.17 (m,

1H), 7.25-7.27 (m, 1H), 7.37-7.55 (m, 6H), 7.66-7.75 (m, 3H); ${ }^{13} \mathrm{C} \mathrm{NMR}\left(\mathrm{CDCl}_{3}\right)$ 8 85.9, $93.5,121.6,123.8,127.3,127.4,127.5,127.8,128.3,129.0,129.6,129.8,131.8,132.8$, 140.7, 144.0.

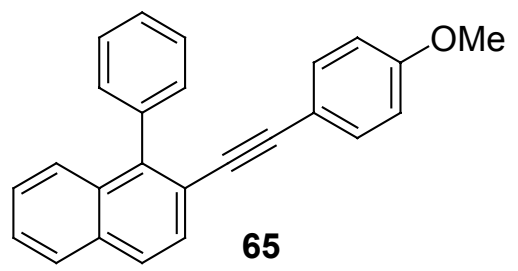

\section{2-[(4-Methoxyphenyl)ethynyl]-1-phenylnaphthalene}

(65). 2-Iodo-1-phenylnaphthalene and 4-ethynylanisole ${ }^{6}$ were employed. Purification by flash chromatography (20:1 
hexane/EtOAc) afforded $0.27 \mathrm{~g}(82 \%)$ of the product as a clear oil: ${ }^{1} \mathrm{H} \mathrm{NMR}\left(\mathrm{CDCl}_{3}\right) \delta 3.81$ (s, 3H), $6.82(\mathrm{dd}, J=6.9,2.1 \mathrm{~Hz}, 2 \mathrm{H}), 7.17(\mathrm{dd}, J=6.9,2.1 \mathrm{~Hz}, 2 \mathrm{H}), 7.43-7.60(\mathrm{~m}, 7 \mathrm{H})$, 7.68-7.72 (m, 2H), 7.83-7.94 (m, 2H); ${ }^{13} \mathrm{C} \mathrm{NMR}\left(\mathrm{CDCl}_{3}\right)$ 8 55.4, 88.9, 93.5, 114, 115.7, $120.7,126.4,126.6,126.8,127.6,127.6,128.1,128.2,128.4,130.9,132.4,133.0,133.1$, $139.3,142.8,159.7$.

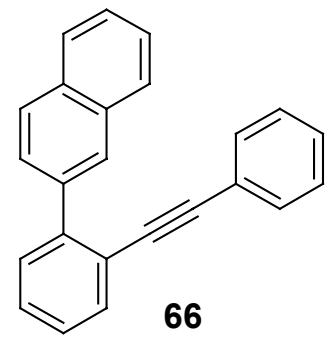

2-[2-(Phenylethynyl)phenyl]naphthalene (66). 2-(2Iodophenyl)naphthalene ${ }^{15}$ and phenylacetylene were employed. Purification by flash chromatography (40:1 hexane/EtOAc) afforded $0.29 \mathrm{~g}(96 \%)$ of the product as a light yellow liquid: ${ }^{1} \mathrm{H} \mathrm{NMR}\left(\mathrm{CDCl}_{3}\right)$

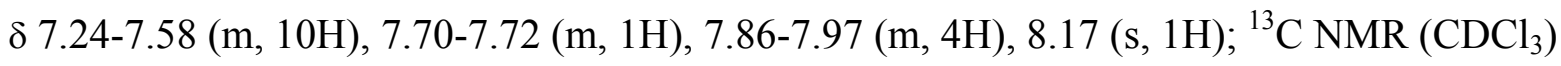
$\delta 89.7,92.7,122.0,123.6,126.2,126.3,127.4,127.5,127.9,128.0,128.3,128.4,128.5$, $128.9,130.0,131.6,132.9,133.3,133.5,138.3,144.0$ (one $\mathrm{sp}^{2}$ carbon missing due to overlap).

\section{General procedure for synthesis of the phenanthrenes ${ }^{7}$}

The following procedure was used to prepare phenanthrenes $22, \mathbf{2 4}, \mathbf{2 6}, \mathbf{2 8}, \mathbf{3 0}$ and chrysene 32. To a solution of 2-(arylethynyl)biphenyl $(0.30 \mathrm{mmol})$ in $\mathrm{CH}_{2} \mathrm{Cl}_{2}(3 \mathrm{~mL})$ under $\mathrm{N}_{2}$ was added $\mathrm{ICl}$ (1.2 equiv) in $\mathrm{CH}_{2} \mathrm{Cl}_{2}(0.5 \mathrm{~mL})$ at $-78^{\circ} \mathrm{C}$. The reaction mixture was stirred at $-78{ }^{\circ} \mathrm{C}$ for $1 \mathrm{~h}$ unless otherwise indicated. The reaction mixture was then diluted with diethyl ether $(50 \mathrm{~mL})$, washed with $25 \mathrm{~mL}$ of satd aq $\mathrm{Na}_{2} \mathrm{~S}_{2} \mathrm{O}_{3}$, dried $\left(\mathrm{MgSO}_{4}\right)$, and filtered. The solvent was evaporated under reduced pressure and the product was purified by chromatography on a silica gel column. 


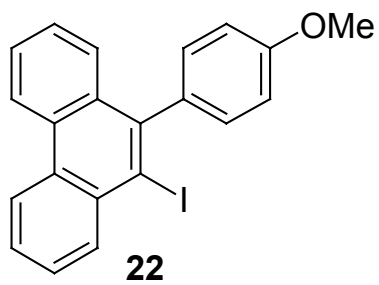

\section{9-Iodo-10-(4-methoxyphenyl)phenanthrene (22).}

Purification by flash chromatography (30:1 hexane/EtOAc) afforded $0.122 \mathrm{~g}(99 \%)$ of the product as a white solid: $\mathrm{mp} 170-$ $171{ }^{\circ} \mathrm{C} ;{ }^{1} \mathrm{H} \mathrm{NMR}\left(\mathrm{CDCl}_{3}\right) \delta 3.94(\mathrm{~s}, 3 \mathrm{H}), 7.09(\mathrm{dd}, J=2.1,6.6 \mathrm{~Hz}$, 2H), $7.21(\mathrm{dd}, J=2.1,6.6 \mathrm{~Hz}, 2 \mathrm{H}), 7.40-7.49(\mathrm{~m}, 2 \mathrm{H}), 7.64-7.72(\mathrm{~m}, 3 \mathrm{H}), 8.45-8.49(\mathrm{~m}, 1 \mathrm{H})$, 8.67-8.78 (m, 2H); ${ }^{13} \mathrm{C} \mathrm{NMR}\left(\mathrm{CDCl}_{3}\right) \delta 55.6,107.7,114.0,122.8,122.9,127.2,127.3,127.7$, $128.3,129.0,130.5,130.8,131.3,132.7,132.9,135.0,138.2,145.3,159.4$; IR (neat) 3066, 3024, 2834, $1610 \mathrm{~cm}^{-1}$; HRMS $\mathrm{m} / z$ 410.0172 (calcd for $\mathrm{C}_{21} \mathrm{H}_{15} \mathrm{IO}, 410.0168$ ).

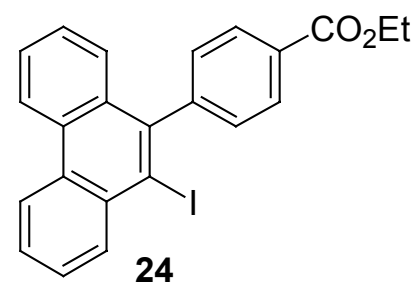

Ethyl 4-(10-iodophenanthren-9-yl)benzoate (24). The reaction mixture was stirred at room temperature for $1 \mathrm{~h}$. Purification by flash chromatography (15:1 hexane/EtOAc) afforded $0.136 \mathrm{~g} \mathrm{(100 \% )} \mathrm{of} \mathrm{the} \mathrm{product} \mathrm{as} \mathrm{a} \mathrm{white} \mathrm{solid:} \mathrm{mp} 152-$ $153{ }^{\circ} \mathrm{C} ;{ }^{1} \mathrm{H}$ NMR $\left(\mathrm{CDCl}_{3}\right) \delta 1.46(\mathrm{t}, J=7.2 \mathrm{~Hz}, 3 \mathrm{H}), 4.47$ (q, $\left.J=7.2 \mathrm{~Hz}, 2 \mathrm{H}\right), 7.30-7.45(\mathrm{~m}$, 4H), 7.66-7.75 (m, 3H), 8.26 (dd, $J=1.8,6.6 \mathrm{~Hz}, 2 \mathrm{H}), 8.45-8.49$ (m, $1 \mathrm{H}), 8.68-8.78$ (m, 2H);

${ }^{13} \mathrm{C}$ NMR $\left(\mathrm{CDCl}_{3}\right) \delta 14.6,61.4,106.0,122.9,123.0,127.4,127.5,128.0,128.4,128.5,130.1$, 130.3, 130.4, 130.5, 130.8, 132.1, 132.5, 134.9, 144.6, 150.0, 166.7; IR $\left(\mathrm{CH}_{2} \mathrm{Cl}_{2}\right) 3069,2979$, $1714 \mathrm{~cm}^{-1}$; HRMS m/z 452.0278 (calcd for $\mathrm{C}_{23} \mathrm{H}_{17} \mathrm{IO}_{2}, 452.0273$ ).

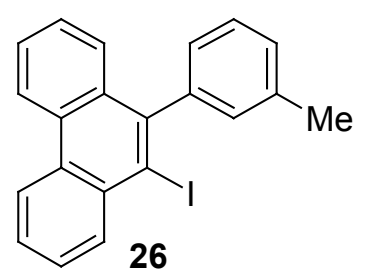

9-Iodo-10-(3-methylphenyl)phenanthrene (26). Purification by flash chromatography (30:1 hexane/EtOAc) afforded $0.117 \mathrm{~g}(99 \%)$ of the product as a white solid: $\mathrm{mp} 134-135{ }^{\circ} \mathrm{C} ;{ }^{1} \mathrm{H} \mathrm{NMR}\left(\mathrm{CDCl}_{3}\right) \delta$ 2.44 (s, 3H), 7.07-7.09 (m, 2H), 7.30-7.32 (m, 1H), 7.41-7.45 (m, 3H), 7.63-7.70 (m, 3H), 8.45-8.48 (m, 1H), 8.67-8.73 (m, 2H); ${ }^{13} \mathrm{C}$ NMR $\left(\mathrm{CDCl}_{3}\right) \delta 21.7,106.5,122.6,122.7,127.1$, $127.1,127.5,128.1,128.4,128.5,128.8,130.3,130.6,130.6,132.5,132.5,134.7,138.1$, 
145.4, 145.5 (one $\mathrm{sp}^{2}$ carbon missing due to overlap); IR $\left(\mathrm{CH}_{2} \mathrm{Cl}_{2}\right) 3067,2971,2921,1602$, $1563 \mathrm{~cm}^{-1}$; HRMS m/z 394.0226 (calcd for $\mathrm{C}_{21} \mathrm{H}_{15} \mathrm{I}, 394.0219$ ).

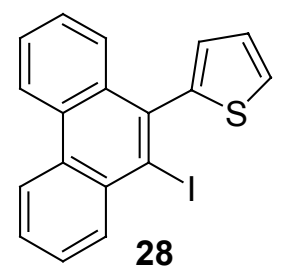

9-Iodo-10-(thiophen-2-yl)phenanthrene (28). Purification by flash $(\mathrm{m}, 1 \mathrm{H}), 7.23-7.26(\mathrm{~m}, 1 \mathrm{H}), 7.45-7.76(\mathrm{~m}, 6 \mathrm{H}), 8.44-8.49(\mathrm{~m}, 1 \mathrm{H}), 8.66-8.75(\mathrm{~m}, 2 \mathrm{H}) ;{ }^{13} \mathrm{C}$ $\operatorname{NMR}\left(\mathrm{CDCl}_{3}\right) \delta 110.5,122.7,122.9,126.5,127.2,127.5,128.2,128.4,128.7,128.8,130.3$, 131.1, 132.6, 133.2, 135.3, 138.4, 146.5; IR (neat) 2925, 1464, $1216 \mathrm{~cm}^{-1} ; \mathrm{HRMS} \mathrm{m/z}$ 385.9631 (calcd for $\mathrm{C}_{18} \mathrm{H}_{11} \mathrm{IS}, 385.9626$ ).

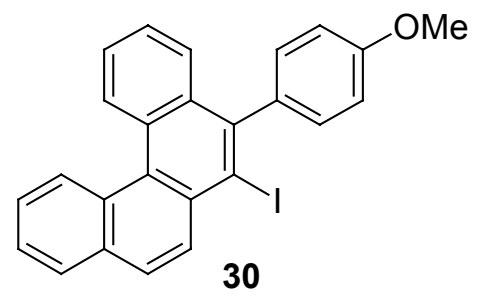

6-Iodo-5-(4-methoxyphenyl)benzo[c]phenanthrene (30). Purification by flash chromatography (30:1 hexane/EtOAc) afforded $0.138 \mathrm{~g}(97 \%)$ of the product as a white solid: $\mathrm{mp}$ 186-187 ${ }^{\circ} \mathrm{C} ;{ }^{1} \mathrm{H}$ NMR $\left(\mathrm{CDCl}_{3}\right) \delta 3.94(\mathrm{~s}, 3 \mathrm{H}), 7.08-7.12(\mathrm{~m}$, 2H), 7.23-7.26 (m, 2H), 7.42-7.47 (m, 1H), 7.57-7.69 (m, 4H), $7.94(\mathrm{~d}, J=9.0 \mathrm{~Hz}, 1 \mathrm{H}), 8.04-$ $8.06(\mathrm{~m}, 1 \mathrm{H}), 8.42(\mathrm{~d}, J=9.0 \mathrm{~Hz}, 1 \mathrm{H}), 9.01-9.04(\mathrm{~m}, 2 \mathrm{H}) ;{ }^{13} \mathrm{C} \mathrm{NMR}\left(\mathrm{CDCl}_{3}\right) \delta 55.6,107.3$, $114.1,126.4,126.6,126.7,126.8,128.4,128.4,128.6,128.6,128.8,129.0,129.7,130.2$ 131.3, 131.5, 132.4, 133.8, 133.8, 138.0, 145.0, 159.4; IR (neat) 2950, 1606, $1506 \mathrm{~cm}^{-1}$; HRMS $m / z 460.0330$ (calcd for $\mathrm{C}_{25} \mathrm{H}_{17} \mathrm{IO}, 460.0324$ ).<smiles>Ic1c(-c2ccccc2)c2c3ccccc3ccc2c2ccccc12</smiles>
6-Iodo-5-phenylchrysene (32). Purification by flash chromatography (40:1 hexane/EtOAc) afforded $98 \mathrm{mg}(76 \%)$ of the product as a yellow solid: $\mathrm{mp} 168-169^{\circ} \mathrm{C} ;{ }^{1} \mathrm{H}$ NMR $\left(\mathrm{CDCl}_{3}\right) \delta 7.07(\mathrm{t}, J=6.9 \mathrm{~Hz}, 1 \mathrm{H}), 7.33-$ $7.57(\mathrm{~m}, 7 \mathrm{H}), 7.71-7.76(\mathrm{~m}, 2 \mathrm{H}), 8.89(\mathrm{~d}, J=6.5 \mathrm{~Hz}, 1 \mathrm{H}), 8.04(\mathrm{~d}, J=7.6$ $\mathrm{Hz}, 1 \mathrm{H}), 8.56-8.60(\mathrm{~m}, 1 \mathrm{H}), 8.78(\mathrm{~d}, J=7.0 \mathrm{~Hz}, 2 \mathrm{H}) ;{ }^{13} \mathrm{C} \mathrm{NMR}\left(\mathrm{CDCl}_{3}\right) \delta 111.5,121.3$, 
$123.7,125.4,126.1,127.7,128.2,128.4,128.6,128.9,129.0,129.2,129.3,130.4,130.7$, 130.8, 131.1, 133.5, 133.8, 135.3, 144.3, 150.0; IR (neat) $2922 \mathrm{~cm}^{-1}$; HRMS $m / z 430.0025$ (calcd for $\mathrm{C}_{24} \mathrm{H}_{15} \mathrm{I}, 430.0219$ ).

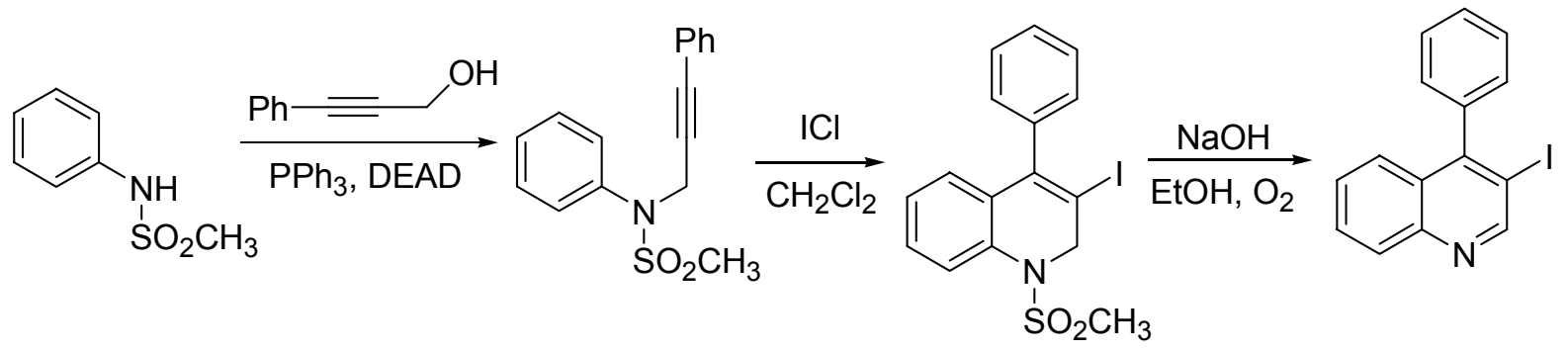

3-Iodo-4-phenylquinoline (34). To a solution of $N$-phenylmethanesulfonamide ${ }^{8}(0.513$ $\mathrm{g}, 3.0 \mathrm{mmol}), \mathrm{PPh}_{3}(1.18 \mathrm{~g}, 4.5 \mathrm{mmol})$ and 3-phenylpropargyl alcohol (0.594 g, $\left.4.5 \mathrm{mmol}\right)$ in anhydrous THF $(30 \mathrm{~mL})$ at $0{ }^{\circ} \mathrm{C}$ was added $\operatorname{DEAD}(0.784 \mathrm{~g}, 4.5 \mathrm{mmol})$. The resulting solution was stirred at $0{ }^{\circ} \mathrm{C}$ for $1 \mathrm{~h}$ and an additional $3 \mathrm{~h}$ at room temperature. The mixture was washed with brine $(30 \mathrm{~mL})$ and the organic layer was dried $\left(\mathrm{Na}_{2} \mathrm{SO}_{4}\right)$, filtered, and the solvent removed under reduced pressure. The residue was purified by chromatography on a silica gel column using 3:1 hexanes/ethyl acetate to obtain $0.534 \mathrm{~g} \mathrm{(63 \% )} \mathrm{of} N$-phenyl- $N$-(3phenyl-2-propyn-1-yl)methanesulfonamide as a white solid: $\mathrm{mp} 76-77{ }^{\circ} \mathrm{C} ;{ }^{1} \mathrm{H} \mathrm{NMR}\left(\mathrm{CDCl}_{3}\right)$ $\delta 3.08(\mathrm{~s}, 3 \mathrm{H}), 4.67(\mathrm{~s}, 2 \mathrm{H}), 7.34-7.46(\mathrm{~m}, 8 \mathrm{H}), 7.62-7.66(\mathrm{~m}, 2 \mathrm{H}) ;{ }^{13} \mathrm{C} \mathrm{NMR}\left(\mathrm{CDCl}_{3}\right) \delta 39.2$, $42.3,84.4,86.3,122.3,127.7,128.4,128.7,129.1,129.7,131.9,140.5$. To a solution of $N$ phenyl- $N$-(3-phenyl-2-propyn-1-yl)methanesulfonamide (71.2 $\mathrm{mg}, 0.25 \mathrm{mmol}$ ) in $\mathrm{CH}_{2} \mathrm{Cl}_{2}$ (3.0 mL) at $-78{ }^{\circ} \mathrm{C}$ was added $\mathrm{ICl}(48.7 \mathrm{mg}, 0.3 \mathrm{mmol})$ in $\mathrm{CH}_{2} \mathrm{Cl}_{2}(0.5 \mathrm{~mL})$ and the resulting solution was stirred at this temperature for $1 \mathrm{~h}$. The reaction mixture was washed with satd aq $\mathrm{Na}_{2} \mathrm{~S}_{2} \mathrm{O}_{3}(20 \mathrm{~mL})$ and the organic layer dried $\left(\mathrm{Na}_{2} \mathrm{SO}_{4}\right)$, filtered and the solvent removed under reduced pressure. The residue was purified by chromatography on a silica gel column 
using 5:1 hexanes/ethyl acetate to obtain $82.2 \mathrm{mg}$ ( $80 \%$ ) of 3-iodo-1-methanesulfonyl-4phenyl-1,2-dihydroquinoline as a white solid: $\mathrm{mp} 173-175{ }^{\circ} \mathrm{C} ;{ }^{1} \mathrm{H}$ NMR $\left(\mathrm{CDCl}_{3}\right) \delta 2.89$ (s, 3H), $4.82(\mathrm{~s}, 2 \mathrm{H}), 6.80(\mathrm{dd}, J=7.8,1.2 \mathrm{~Hz}, 1 \mathrm{H}), 7.11-7.16(\mathrm{~m}, 3 \mathrm{H}), 7.30-7.33(\mathrm{~m}, 1 \mathrm{H}), 7.44-$ $7.48(\mathrm{~m}, 3 \mathrm{H}), 7.62(\mathrm{dd}, J=8.1,0.9 \mathrm{~Hz}, 1 \mathrm{H}) ;{ }^{13} \mathrm{C} \mathrm{NMR}\left(\mathrm{CDCl}_{3}\right) \delta 38.6,56.7,92.0,126.9$, 127.2, 127.2, 128.6, 128.8, 129.0, 129.2, 130.7, 134.5, 140.3, 143.9. A solution of 3-iodo-1methanesulfonyl-4-phenyl-1,2-dihydroquinoline $(0.103 \mathrm{~g}, 0.25 \mathrm{mmol})$ and $\mathrm{NaOH}(0.10 \mathrm{~g}, 2.5$ $\mathrm{mmol})$ in $\mathrm{EtOH}(10 \mathrm{~mL})$ was stirred at $50{ }^{\circ} \mathrm{C}$ under $\mathrm{O}_{2}(1 \mathrm{~atm})$ for $12 \mathrm{~h}$. The reaction mixture was diluted with diethyl ether $(50 \mathrm{~mL})$ and washed with brine $(50 \mathrm{~mL})$. The organic layer was dried $\left(\mathrm{Na}_{2} \mathrm{SO}_{4}\right)$, filtered, and the solvent removed under reduced pressure. The residue was purified by column chromatography on a silica gel column using 5:1 hexanes/ethyl acetate to afford $76.1 \mathrm{mg}$ (92\%) of the desired compound $\mathbf{3 4}$ as a white solid: $\mathrm{mp}$ 131-132 ${ }^{\circ} \mathrm{C} ;{ }^{1} \mathrm{H}$ NMR $\left(\mathrm{CDCl}_{3}\right) \delta$ 7.25-7.28 (m, 2H), 7.42-7.48 (m, 2H), 7.52-7.55 (m, 3H), 7.69-7.74 (m, $1 \mathrm{H}), 8.12(\mathrm{~d}, J=8.8 \mathrm{~Hz}, 1 \mathrm{H}), 9.24(\mathrm{~s}, 1 \mathrm{H}) ;{ }^{13} \mathrm{C} \mathrm{NMR}\left(\mathrm{CDCl}_{3}\right) \delta 96.4,126.8,127.4,128.7$, $129.0,129.1,129.5,129.8,140.4,147.2,152.4,156.6$ (one $\mathrm{sp}^{2}$ carbon missing due to overlap); IR $\left(\mathrm{CH}_{2} \mathrm{Cl}_{2}\right) 3061,2918,1566,1501,1485 \mathrm{~cm}^{-1}$; HRMS m/z 330.9864 (calcd for $\left.\mathrm{C}_{15} \mathrm{H}_{10} \mathrm{IN}, 330.9858\right)$. 
<smiles>Cc1c[nH]c2ccccc12</smiles>

1. $n$-BuLi

2. $\mathrm{CO}_{2}$ 3. $t$-BuLi

4. $\mathrm{ICH}_{2} \mathrm{CH}_{2} \mathrm{I}$<smiles>Cc1c(I)[nH]c2ccccc12</smiles>

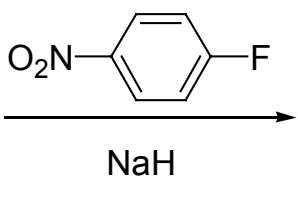<smiles>Cc1c(I)n(-c2ccc([N+](=O)[O-])cc2)c2ccccc12</smiles>

$\underset{\mathrm{NH}_{2} \mathrm{NH}_{2}, \mathrm{FeCl}_{3}}{\longrightarrow}$

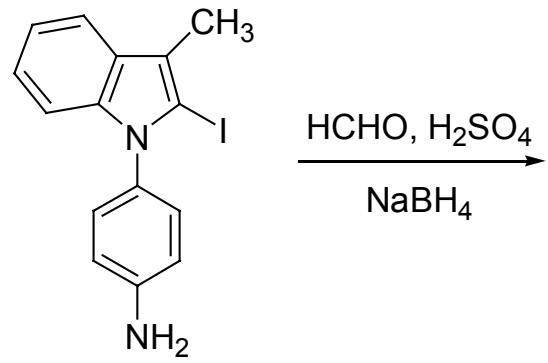

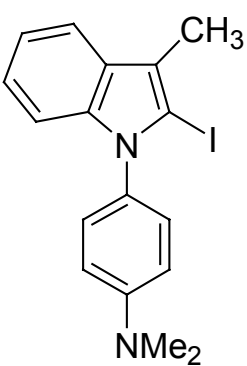

38

2-Iodo-3-methylindole. To a solution of 3-methylindole $(2.64 \mathrm{~g}, 20.0 \mathrm{mmol})$ in $55 \mathrm{~mL}$ of dry THF was added dropwise $8.4 \mathrm{~mL}$ of $n$-BuLi $(2.5 \mathrm{M}$ in hexane $)$ at $-78^{\circ} \mathrm{C}$ under an $\mathrm{Ar}$ atmosphere. The resulting suspension was stirred at $-78^{\circ} \mathrm{C}$ for $20 \mathrm{~min}$. Carbon dioxide was bubbled through the reaction mixture for $30 \mathrm{~min}$ to form a clear yellow solution. The reaction mixture was allowed to warm to $25{ }^{\circ} \mathrm{C}$ and the solvent was removed under reduced pressure. To the residue was added $50 \mathrm{~mL}$ of dry THF and the suspension was cooled to -78 ${ }^{\circ} \mathrm{C} .12 .5 \mathrm{Ml}$ of $t$-BuLi (1.7 M pentane) was added to the suspension and the resulting orange reaction mixture was stirred at $-78^{\circ} \mathrm{C}$ for $1 \mathrm{~h}$. A solution of $\mathrm{ICH}_{2} \mathrm{CH}_{2} \mathrm{I}(5.64 \mathrm{~g}, 20.0 \mathrm{mmol})$ in $15 \mathrm{~mL}$ of dry THF was added dropwise and the resulting yellow solution was stirred at -78 ${ }^{\circ} \mathrm{C}$ for $1 \mathrm{~h}$. Then the reaction mixture was allowed to warm to $25{ }^{\circ} \mathrm{C}$ and washed with $50 \mathrm{~mL}$ of satd aqueous $\mathrm{NH}_{4} \mathrm{Cl}$. The organic layer was collected, dried over $\mathrm{Na}_{2} \mathrm{SO}_{4}$, and concentrated under reduced pressure. The residue was purified by column $(5: 1$ hexane/EtOAc) to afford $4.98 \mathrm{~g}$ of 2-iodo-3-methylindole as a yellow oil in $97 \%$ yield with spectral properties identical to those previously reported. ${ }^{9}$ 
2-Iodo-3-methyl-1-(4-nitrophenyl)indole. To a suspension of $\mathrm{NaH}$ (5.5 mmol) in 20 $\mathrm{mL}$ of DMF was added $1.28 \mathrm{~g}$ of 2-iodo-3-methylindole $(5.0 \mathrm{mmol})$ at $0{ }^{\circ} \mathrm{C}$ under an $\mathrm{Ar}$ atmosphere and lots of bubbles were generated. The resulting yellow suspension was stirred at $0{ }^{\circ} \mathrm{C}$ for $40 \mathrm{~min}$ and a solution of 1-fluoro-4-nitrobenzene $(0.846 \mathrm{~g}, 6.0 \mathrm{mmol})$ in $10 \mathrm{~mL}$ of DMF was added dropwise. After $12 \mathrm{~h}$, the reaction was diluted with $30 \mathrm{~mL}$ of $\mathrm{Et}_{2} \mathrm{O}$ and washed with $30 \mathrm{~mL}$ of brine. The organic layer was collected, dried over $\mathrm{Na}_{2} \mathrm{SO}_{4}$, and concentrated under reduced pressure. The residue was purified by column chromatography (15:1 hexane/EtOAc) to afford $1.07 \mathrm{~g}$ of the indicated compound in a $57 \%$ yield as a yellow solid: $\mathrm{mp} 123-126{ }^{\circ} \mathrm{C} ;{ }^{1} \mathrm{H}$ NMR $\left(\mathrm{CDCl}_{3}\right) 2.39$ (s, 3H), 7.13-7.20 (m, 3H), 7.54-7.60 (m, 3H), 8.37-8.42 (m, $2 \mathrm{H}) ;{ }^{13} \mathrm{C} \mathrm{NMR}\left(\mathrm{CDCl}_{3}\right) \delta 12.8,85.2,110.3,118.9,121.1,121.5,123.4,124.9$, $129.2,129.5,139.3,144.7,147.0$.

1-(4-Aminophenyl)-2-iodo-3-methylindole. To a 6 dram vial was added $0.80 \mathrm{~g}$ of 2 iodo-3-methyl-1-(4-nitrophenyl)indole (2.1 mmol), $17 \mathrm{~mL}$ of $\mathrm{CH}_{3} \mathrm{OH}, 8.5 \mathrm{mg}$ of $\mathrm{FeCl}_{3} \cdot 6 \mathrm{H}_{2} \mathrm{O}$ (0.32 mmol), $4.3 \mathrm{mg}$ of active carbon $(3.6 \mathrm{mmol})$, and $0.21 \mathrm{~mL}$ of $\mathrm{NH}_{2} \mathrm{NH}_{2} \cdot \mathrm{H}_{2} \mathrm{O}(4.2 \mathrm{mmol})$. The resulting mixture was stirred at $25^{\circ} \mathrm{C}$ for 5 min and was heated to $70{ }^{\circ} \mathrm{C}$ (a sealed tube reaction). After $7 \mathrm{~h}$, the reaction was allowed to cool to $25^{\circ} \mathrm{C}$ and filtered. The colorless filtrate was concentrated under reduced pressure and the residue was purified by column chromatography (2:1 hexane/EtOAc) to afford $0.60 \mathrm{~g}$ of the indicated compound in an $82 \%$ yield as a yellow oil: ${ }^{1} \mathrm{H}$ NMR $\left(\mathrm{CDCl}_{3}\right) 2.38$ (s, 3H), 3.94 (br s, $\left.2 \mathrm{H}\right), 6.78-6.80(\mathrm{~m}, 2 \mathrm{H})$, 7.06$7.10(\mathrm{~m}, 5 \mathrm{H}), 7.54-7.56(\mathrm{~m}, 1 \mathrm{H}) ;{ }^{13} \mathrm{C} \mathrm{NMR}\left(\mathrm{CDCl}_{3}\right) \delta$ 12.7, 88.8, 110.9, 115.4, 118.0, 118.2, $119.7,122.2,128.5,130.2,140.1,146.7$ (one $\mathrm{sp}^{2}$ carbon missing due to overlap).

1-(4-Dimethylaminophenyl)-2-iodo-3-methylindole (38). To a mixture of formaldehyde (37\% of aqueous solution, $0.40 \mathrm{~mL}, 4.98 \mathrm{mmol}$ ) and $\mathrm{H}_{2} \mathrm{SO}_{4}(3 \mathrm{M}, 0.69 \mathrm{~mL}$, 
$2.1 \mathrm{mmol})$ was added a slurry of $\mathrm{NaBH}_{4}(0.22 \mathrm{~g}, 5.8 \mathrm{mmol})$ and 1-(4-aminophenyl)-2-iodo-3methylindole $(0.29 \mathrm{~g}, 0.83 \mathrm{mmol})$ in $7 \mathrm{~mL}$ of THF at $0{ }^{\circ} \mathrm{C}$. Lots of bubbles were generated in this process and the resulting yellow suspension was stirred at $0{ }^{\circ} \mathrm{C}$ for $10 \mathrm{~min}$. The reaction mixture was diluted with $30 \mathrm{~mL}$ of $\mathrm{Et}_{2} \mathrm{O}$, and washed with satd aq $\mathrm{NaHCO}_{3}(30 \mathrm{~mL})$ and brine $(20 \mathrm{~mL})$. The organic layer was collected, dried over $\mathrm{NaSO}_{4}$, and filtered. Removal of solvent under reduced pressure afforded $0.26 \mathrm{~g}$ of the indicated compound in an $83 \%$ yield as a yellow solid: $\mathrm{mp} 149-150{ }^{\circ} \mathrm{C} ;{ }^{1} \mathrm{H}$ NMR $\left(\mathrm{CDCl}_{3}\right) 2.38(\mathrm{~s}, 3 \mathrm{H}), 3.04(\mathrm{~s}, 6 \mathrm{H}), 6.79(\mathrm{~d}, J=$ $8.8 \mathrm{~Hz}, 2 \mathrm{H}), 7.05-7.10(\mathrm{~m}, 3 \mathrm{H}), 7.16(\mathrm{~d}, J=8.8 \mathrm{~Hz}, 2 \mathrm{H}), 7.54-7.56(\mathrm{~m}, 1 \mathrm{H}),{ }^{13} \mathrm{C} \mathrm{NMR}$ $\left(\mathrm{CDCl}_{3}\right) \delta 12.7,40.7,89.3,111.0,112.3,117.8,118.2,119.6,122.1,128.1,128.4,129.9$, 140.2, 150.3; IR $\left(\mathrm{CH}_{2} \mathrm{Cl}_{2}\right) 3053,2986,1524 \mathrm{~cm}^{-1}$; HRMS $m / z 376.0441$ (calcd for $\mathrm{C}_{17} \mathrm{H}_{17} \mathrm{IN}_{2}$, 376.0437).

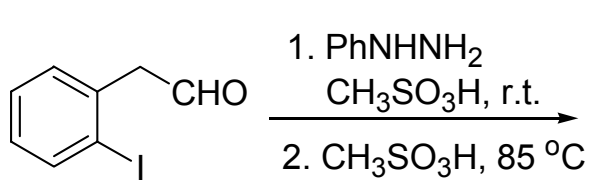

3-(2-Iodophenyl)indole (66). To a solution of (2-iodophenyl)acetaldehyde ${ }^{10}(0.738 \mathrm{~g}$, $3.0 \mathrm{mmol})$ in $15 \mathrm{~mL}$ of absolute ethanol was added $0.356 \mathrm{~g}$ of $\mathrm{PhNHNH}_{2}(3.3 \mathrm{mmol})$ and $57.6 \mathrm{mg}$ of $\mathrm{CH}_{3} \mathrm{SO}_{3} \mathrm{H}(0.6 \mathrm{mmol})$. The resulting yellow solution was then stirred at room temperature for $1 \mathrm{~h}$. Another $0.519 \mathrm{~g}$ of $\mathrm{CH}_{3} \mathrm{SO}_{3} \mathrm{H}(5.4 \mathrm{mmol})$ was then added to the reaction mixture and the reaction was stirred at $85{ }^{\circ} \mathrm{C}$. After $2 \mathrm{~d}$, the reaction was complete and was allowed to cool to room temperature. The ethanol was removed under reduced pressure and the residue was diluted with $\mathrm{Et}_{2} \mathrm{O}(30 \mathrm{~mL})$, washed with brine $(30 \mathrm{~mL})$, dried over $\mathrm{Na}_{2} \mathrm{SO}_{4}$, 
filtered and concentrated. The residue was purified by flash chromatography $(5: 1$ hexane/EtOAc) to afford $0.41 \mathrm{~g}$ of compound $\mathbf{6 6}$ (43\% yield) as a yellow oil: ${ }^{1} \mathrm{H}$ NMR $\left(\mathrm{CDCl}_{3}\right) \delta$ 7.01-7.05 (m, 1H), 7.14-7.18 (m, 1H), 7.23-7.27 (m, 1H), 7.38-7.49 (m, 4H), 7.54 $(\mathrm{d}, J=8.0 \mathrm{~Hz}, 1 \mathrm{H}), 8.01(\mathrm{dd}, J=1.2,8.0 \mathrm{~Hz}, 1 \mathrm{H}), 8.27(\mathrm{br} \mathrm{s}, 1 \mathrm{H}) ;{ }^{13} \mathrm{C} \mathrm{NMR}\left(\mathrm{CDCl}_{3}\right) \delta 101.0$, $111.5,120.3,120.4,122.6,123.8,126.8,128.2,128.5,131.6,135.8,140.0,140.1$ (one $\mathrm{sp}^{2}$ carbon missing due to overlap).

1-Benzyl-3-(2-iodophenyl)indole (40). To a suspension of $30 \mathrm{mg}$ of $\mathrm{NaH}(0.75 \mathrm{mmol}$, $60 \%$ in mineral oil) in DMF ( $2 \mathrm{~mL})$ was added dropwise a solution of compound 66 ( $0.16 \mathrm{~g}$, $0.5 \mathrm{mmol})$ in DMF $(4 \mathrm{~mL})$ at $0{ }^{\circ} \mathrm{C}$. A lot of bubbles were generated. The resulting brown solution was stirred at $0{ }^{\circ} \mathrm{C}$ for $45 \mathrm{~min}$ and a solution of $\mathrm{PhCH}_{2} \mathrm{Cl}(0.127 \mathrm{~g}, 1.0 \mathrm{mmol})$ in DMF $(1 \mathrm{~mL})$ was added dropwise at $0{ }^{\circ} \mathrm{C}$. The resulting mixture was stirred at $0{ }^{\circ} \mathrm{C}$ for $12 \mathrm{~h}$. The reaction mixture was diluted with $\mathrm{Et}_{2} \mathrm{O}(30 \mathrm{~mL})$, washed with brine $(30 \mathrm{~mL})$, dried over $\mathrm{Na}_{2} \mathrm{SO}_{4}$, filtered and concentrated under reduced pressure. The residue was purified by flash chromatography (20:1 hexane/EtOAc) to afford $0.155 \mathrm{~g}$ of the indicated compound $\mathbf{4 0}$ (76\% yield) as a colorless oil: ${ }^{1} \mathrm{H}$ NMR $\left(\mathrm{CDCl}_{3}\right) \delta 5.38(\mathrm{~s}, 2 \mathrm{H}), 6.98-7.02(\mathrm{~m}, 1 \mathrm{H}), 7.12-7.16(\mathrm{~m}$, 1H), 7.18-7.33 (m, 8H), 7.37-7.41 (m, 1H), $7.49(\mathrm{dd}, J=1.6,7.6 \mathrm{~Hz}, 1 \mathrm{H}), 7.54-7.56(\mathrm{~m}, 1 \mathrm{H})$, $7.99(\mathrm{dd}, J=1.2,8.0 \mathrm{~Hz}, 1 \mathrm{H}) ;{ }^{13} \mathrm{C} \mathrm{NMR}\left(\mathrm{CDCl}_{3}\right) \delta 50.4,101.1,110.1,119.2,120.1,120.4$, $122.3,127.1,127.5,127.9,128.1,128.2,128.4,129.0,131.6,136.3,137.5,140.0,140.1 ;$ IR (neat) $3055,3029,2921,1613,1585 \mathrm{~cm}^{-1}$; HRMS $m / z 409.0335$ (calcd for $\mathrm{C}_{21} \mathrm{H}_{16} \mathrm{IN}$, 409.0328).

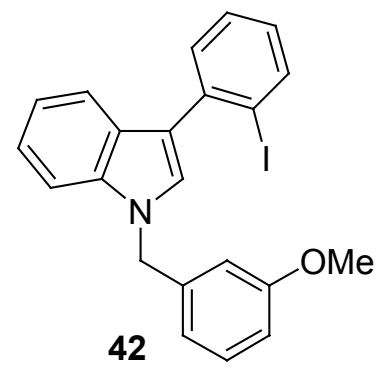

1-(3-Methoxybenzyl)-3-(2-iodophenyl)indole (42). Using the procedure to prepare compound 40 , but employing $0.16 \mathrm{~g}$ of 3 - 
methoxybenzyl chloride $(1.0 \mathrm{mmol})$ afforded $0.193 \mathrm{~g}$ of the indicated compound $\mathbf{4 2}$ in an 88 \% yield as a yellow oil: ${ }^{1} \mathrm{H}$ NMR $\left(\mathrm{CDCl}_{3}\right) \delta 3.72(\mathrm{~s}, 3 \mathrm{H}), 5.34(\mathrm{~s}, 2 \mathrm{H}), 6.71(\mathrm{~s}, 1 \mathrm{H}), 6.77-6.81$ (m, 2H), 6.98-7.02 (m, 1H), 7.12-7.15 (m, 1H), 7.18-7.24 (m, 2H), 7.31-7.33 (m, 2H), 7.37$7.40(\mathrm{~m}, 1 \mathrm{H}), 7.48-7.50(\mathrm{~m}, 1 \mathrm{H}), 7.54(\mathrm{~d}, J=8.0 \mathrm{~Hz}, 1 \mathrm{H}), 7.99(\mathrm{~d}, J=8.0 \mathrm{~Hz}, 1 \mathrm{H}) ;{ }^{13} \mathrm{C} \mathrm{NMR}$ $\left(\mathrm{CDCl}_{3}\right) \delta 50.3,55.4,101.1,110.1,112.7,113.2,119.2,119.3,120.1,120.4,122.3,127.5$, 128.1, 128.2, 128.4, 130.0, 131.6, 136.2, 139.1, 140.0, 140.0, 160.2; IR (neat) 3051, 2934, 1586, $1490 \mathrm{~cm}^{-1}$; HRMS $\mathrm{m} / z 439.0439$ (calcd for $\mathrm{C}_{22} \mathrm{H}_{18} \mathrm{ION}, 439.0433$ ).

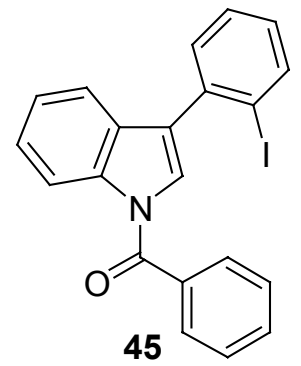

1-Benzoyl-3-(2-iodophenyl)indole (45). Using the procedure to prepare compound 40, but employing of $0.14 \mathrm{~g}$ of benzoyl chloride (1.0 mmol) afforded $0.190 \mathrm{~g}$ of the indicated compound $\mathbf{4 5}$ in a $90 \%$ yield as a pale yellow solid: $\mathrm{mp} 102-103{ }^{\circ} \mathrm{C} ;{ }^{1} \mathrm{H} \mathrm{NMR}\left(\mathrm{CDCl}_{3}\right) \delta$ 7.04-7.08 (m, 1H), 7.32-7.36 (m, 1H), 7.40-7.46 (m, 5H), 7.51-7.55 (m, 2H), 7.58-7.63 (m, 1H), 7.81-7.84 (m, 2H), $7.98(\mathrm{~d}, J=7.6 \mathrm{~Hz}, 1 \mathrm{H}), 8.49-8.51(\mathrm{~m}, 1 \mathrm{H}) ;{ }^{13} \mathrm{C} \mathrm{NMR}\left(\mathrm{CDCl}_{3}\right) \delta 100.2,116.7$, $120.5,124.3,125.3,125.5,126.5,128.3,128.8,129.6,129.6,130.1,131.3,132.3,134.6$, 136.1, 138.1, 140.1, 168.9; IR (neat) 3051, 1686, 1450, $1364 \mathrm{~cm}^{-1}$; HRMS m/z 423.0129 (calcd for $\mathrm{C}_{21} \mathrm{H}_{14} \mathrm{ION}, 423.0120$ ).
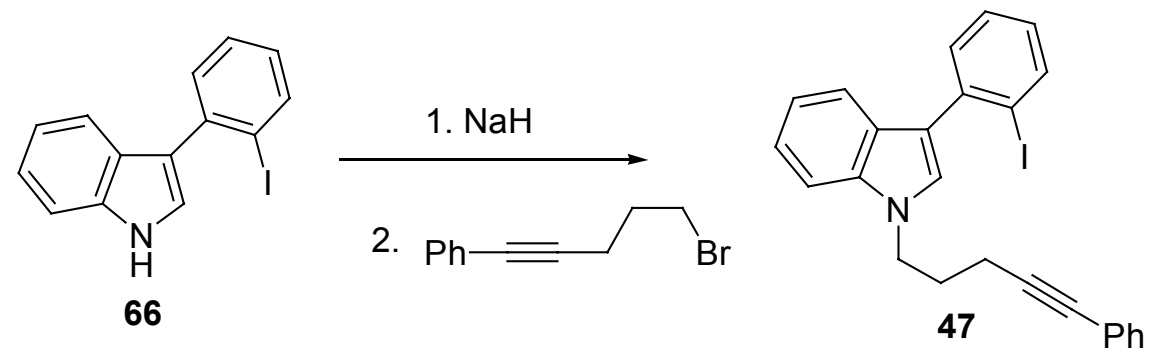
3-(2-Iodophenyl)-1-(5-phenyl-4-pentynyl)indole (47). To a suspension of $\mathrm{NaH}$ (45.7 $\mathrm{mg}, 1.14 \mathrm{mmol}, 60 \%$ in mineral oil) in DMF (3 mL) was added dropwise a solution of compound $66(0.243 \mathrm{~g}, 0.76 \mathrm{mmol})$ in DMF $(5 \mathrm{~mL})$ at $0{ }^{\circ} \mathrm{C}$. A lot of bubbles were generated. The resulting brown solution was stirred at $0{ }^{\circ} \mathrm{C}$ for $45 \mathrm{~min}$ and a solution of 5-bromo-1phenyl-1-pentyne $(0.34 \mathrm{~g}, 1.52 \mathrm{mmol})$ in DMF $(2 \mathrm{~mL})$ was added dropwise at $0{ }^{\circ} \mathrm{C}$. The resulting mixture was stirred at $0{ }^{\circ} \mathrm{C}$ for $12 \mathrm{~h}$, diluted with $\mathrm{Et}_{2} \mathrm{O}(30 \mathrm{~mL})$, washed with brine $(30 \mathrm{~mL})$, dried over $\mathrm{Na}_{2} \mathrm{SO}_{4}$, filtered and concentrated under reduced pressure. The residue was purified by flash chromatography (20:1 hexane/EtOAc) to afford $0.30 \mathrm{~g}$ of the indicated compound $47\left(85 \%\right.$ yield) as a yellow oil: ${ }^{1} \mathrm{H}$ NMR $\left(\mathrm{CDCl}_{3}\right) \delta 2.13-2.22(\mathrm{~m}, 2 \mathrm{H}), 2.45(\mathrm{t}, J$ $=8.8 \mathrm{~Hz}, 2 \mathrm{H}), 4.41(\mathrm{t}, J=8.8 \mathrm{~Hz}, 2 \mathrm{H}), 6.98-7.03(\mathrm{~m}, 1 \mathrm{H}), 7.12-7.23(\mathrm{~m}, 1 \mathrm{H}), 7.23-7.33(\mathrm{~m}$, 4H), 7.37-7.50 (m, 6H), 7.54-7.56 (m, 1H), $8.00(\mathrm{dd}, J=1.6,10.8 \mathrm{~Hz}, 1 \mathrm{H}) ;{ }^{13} \mathrm{C} \mathrm{NMR}$ $\left(\mathrm{CDCl}_{3}\right) \delta 17.0,29.1,45.1,82.3,88.6,101.1,109.8,118.7,120.0,120.4,122.1,123.8,127.5$, $128.0,128.1,128.2,128.3,128.5,131.5,131.8,135.9,140.1$ (one $\mathrm{sp}^{2}$ carbon missing due to overlap); IR $\left(\mathrm{CH}_{2} \mathrm{Cl}_{2}\right) 3053,2985,1613,1596,1548 \mathrm{~cm}^{-1}$; HRMS $\mathrm{m} / z 461.0647$ (calcd for $\left.\mathrm{C}_{25} \mathrm{H}_{20} \mathrm{IN}, 461.0641\right)$.<smiles>CS(=O)(=O)c1oc(=O)c2ccccc2c1-c1ccccc1</smiles>

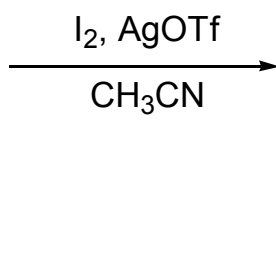<smiles>O=c1oc(I)c(-c2ccccc2)c2ccccc12</smiles>

51

3-Iodo-4-phenylisocoumarin (51). A solution of 4-phenyl-3-

(trimethylsilyl)isocoumarin ${ }^{11}(0.435 \mathrm{~g}, 1.48 \mathrm{mmol}), \mathrm{I}_{2}(1.13 \mathrm{~g}, 4.45 \mathrm{mmol})$, and AgOTf (0.76 
g, $2.96 \mathrm{mmol})$ in $\mathrm{CH}_{3} \mathrm{CN}(20 \mathrm{~mL})$ was heated at $55^{\circ} \mathrm{C}$ for $5 \mathrm{~d}$. The reaction mixture was diluted with diethyl ether $(100 \mathrm{~mL})$, and washed with satd aq $\mathrm{Na}_{2} \mathrm{~S}_{2} \mathrm{O}_{3}(30 \mathrm{~mL})$. The organic layer was dried $\left(\mathrm{Na}_{2} \mathrm{SO}_{4}\right)$, filtered, and the solvent removed under reduced pressure to obtain $0.498 \mathrm{~g}(97 \%)$ of the indicated compound $\mathbf{5 1}$ as a yellow solid. Recrystallization from hexanes/ethyl acetate afforded the indicated compound $\mathbf{5 1}$ as a yellow solid: $\mathrm{mp} 170-171{ }^{\circ} \mathrm{C}$, ${ }^{1} \mathrm{H}$ NMR $\left(\mathrm{CDCl}_{3}\right) \delta 6.97(\mathrm{~d}, J=8.0 \mathrm{~Hz}, 1 \mathrm{H}), 7.26-7.28(\mathrm{~m}, 2 \mathrm{H}), 7.50-7.56(\mathrm{~m}, 4 \mathrm{H}), 7.59-$ $7.63(\mathrm{~m}, 1 \mathrm{H}), 8.31(\mathrm{dd}, J=8.0,0.8 \mathrm{~Hz}, 1 \mathrm{H}) ;{ }^{13} \mathrm{C} \mathrm{NMR}\left(\mathrm{CDCl}_{3}\right) \delta 107.9,119.6,125.6,127.4$, 128.7, 128.9, 129.1, 129.9, 130.5, 135.2, 137.0, 137.3, 161.2; IR $\left(\mathrm{CH}_{2} \mathrm{Cl}_{2}\right) 1736 \mathrm{~cm}^{-1}$; HRMS $m / z 347.9652$ (calcd for $\mathrm{C}_{15} \mathrm{H}_{9} \mathrm{IO}_{2}, 347.9647$ ).
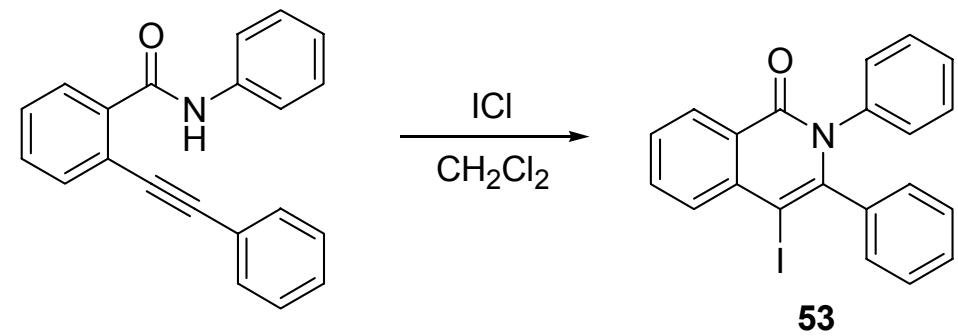

4-Iodo-2,3-diphenyl-2H-isoquinolin-1-one (53). To a solution of $N$-phenyl-2(phenylethynyl)benzamide ${ }^{12}(74.2 \mathrm{mg}, 0.25 \mathrm{mmol})$ in $\mathrm{CH}_{2} \mathrm{Cl}_{2}(3.0 \mathrm{~mL})$ at room temperature was added $\mathrm{ICl}(48.7 \mathrm{mg}, 0.3 \mathrm{mmol})$ in $\mathrm{CH}_{2} \mathrm{Cl}_{2}(0.5 \mathrm{~mL})$ and the resulting solution was stirred at this temperature for $1 \mathrm{~h}$. The reaction mixture was washed with satd aq $\mathrm{Na}_{2} \mathrm{~S}_{2} \mathrm{O}_{3}(20 \mathrm{~mL})$ and the organic layer dried $\left(\mathrm{Na}_{2} \mathrm{SO}_{4}\right)$, filtered and the solvent removed under reduced pressure. The residue was purified by chromatography on a silica gel column using 5:1 hexanes/ethyl acetate to obtain $42.3 \mathrm{mg}(40 \%)$ of the indicated compound $\mathbf{5 3}$ as a yellow solid: $\mathrm{mp} 129-130{ }^{\circ} \mathrm{C} ;{ }^{1} \mathrm{H}$ NMR $\left(\mathrm{CDCl}_{3}\right) \delta$ 7.08-7.11 (m, $\left.1 \mathrm{H}\right), 7.20-7.30(\mathrm{~m}, 3 \mathrm{H}), 7.33-7.38$ (m, 4H), 7.57-7.64 (m, 3H), 7.67-7.72 (m, 1H), 8.03-8.06 (m, $1 \mathrm{H}), 8.84-8.87(\mathrm{~m}, 1 \mathrm{H}) ;{ }^{13} \mathrm{C}$ 
$\operatorname{NMR}\left(\mathrm{CDCl}_{3}\right) \delta$ 75.2, 124.1, 125.1, 125.1, 125.4, 128.1, 128.7, 128.7, 130.5, 130.9, 132.0, 132.7, 135.7, 140.6, 145.0, 147.8, 152.1; IR $\left(\mathrm{CH}_{2} \mathrm{Cl}_{2}\right) 2916,2849,1642,1586,1488,1445$ $\mathrm{cm}^{-1}$; HRMS $m / z 423.0131$ (calcd for $\mathrm{C}_{15} \mathrm{H}_{9} \mathrm{IO}_{2}, 423.0120$ ).

(Boc) $)_{2} \mathrm{O}$

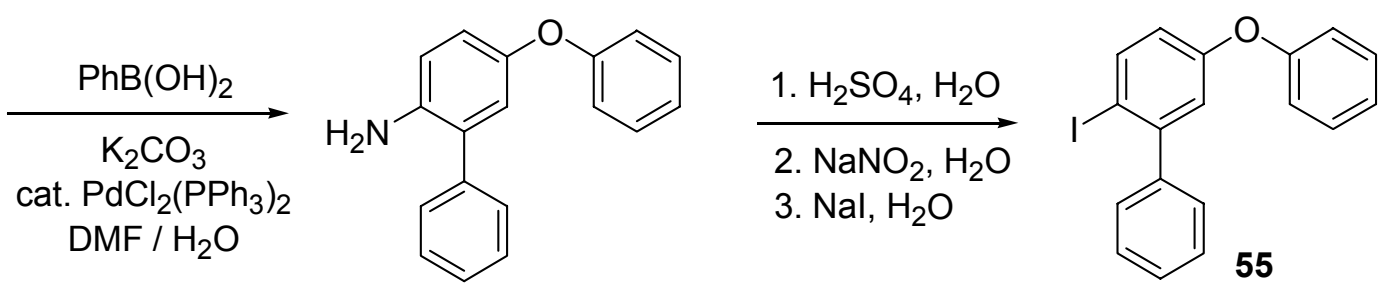

$N$-(4-Phenoxyphenyl)-2,2-dimethylpropanamide. To a solution of 4-phenoxyaniline $(3.33 \mathrm{~g}, 18.0 \mathrm{mmol})$ in $70 \mathrm{~mL}$ of dried THF was added $(\mathrm{Boc})_{2} \mathrm{O}(4.71 \mathrm{~g}, 21.6 \mathrm{mmol})$ and the resulting yellow solution was refluxed at $80{ }^{\circ} \mathrm{C}$ for $6 \mathrm{~h}$. The solvent was removed under reduced pressure and the reddish residue was recrystallized using hexane and EtOAc to afford $4.84 \mathrm{~g}$ of the indicated compound $\left(85 \%\right.$ yield) as white needles: $\mathrm{mp} 109-111{ }^{\circ} \mathrm{C} ;{ }^{1} \mathrm{H}$ NMR $\left(\mathrm{CDCl}_{3}\right) \delta 1.52(\mathrm{~s}, 9 \mathrm{H}), 6.43(\mathrm{br} \mathrm{s}, 1 \mathrm{H}), 6.95-6.98(\mathrm{~m}, 4 \mathrm{H}), 7.06(\mathrm{t}, J=3.6 \mathrm{~Hz}, 1 \mathrm{H})$, 7.29-7.34 (m, 4H); ${ }^{13} \mathrm{C} \mathrm{NMR}\left(\mathrm{CDCl}_{3}\right) \delta 28.6,80.7,118.3,120.2,120.5,123.0,129.9,134.2$ $152.6,153.2,158.1$

$N$-(2-Iodo-4-phenoxyphenyl)-2,2-dimethylpropanamide. To a solution of $N$-(4phenoxyphenyl)-2,2-dimethylpropanamide (2.57 g, $9.02 \mathrm{mmol})$ in $20 \mathrm{~mL}$ of dry diethyl ether was added dropwise $10.6 \mathrm{~mL}$ of $t$ - $\mathrm{BuLi}(1.7 \mathrm{M}$ in pentane, $18.04 \mathrm{mmol})$ at $-78^{\circ} \mathrm{C}$ under Ar. The pale orange solution turned a pale yellow color when half of the $t$-BuLi solution had 
been added and eventually to yellow when all of the $t$-BuLi solution was added. The resulting yellow solution was then stirred at $-78{ }^{\circ} \mathrm{C}$ for 30 min. A solution of $\mathrm{ICH}_{2} \mathrm{CH}_{2} \mathrm{I}$ ( $2.81 \mathrm{~g}, 9.92 \mathrm{mmol}$, recrystallized from diethyl ether) in $20 \mathrm{~mL}$ of dry ether was added dropwise to the reaction mixture and the resulting orange solution was stirred at $-78{ }^{\circ} \mathrm{C}$ for another $30 \mathrm{~min}$. The reaction mixture was allowed to warm up to room temperature and quenched by $50 \mathrm{~mL}$ of water. The organic layer was separated and dried over $\mathrm{Na}_{2} \mathrm{SO}_{4}$, filtered, and concentrated. The residue was purified by flash chromatography (15:1 hexane/EtOAc) to afford $2.3 \mathrm{~g}$ of the desired compound (62\% yield) as a colorless oil: ${ }^{1} \mathrm{H}$ $\operatorname{NMR}\left(\mathrm{CDCl}_{3}\right) \delta 1.53(\mathrm{~s}, 9 \mathrm{H}), 6.68($ br s, $1 \mathrm{H}), 6.96-6.98(\mathrm{~m}, 2 \mathrm{H}), 7.02(\mathrm{dd}, J=2.4,8.8 \mathrm{~Hz}$, 1H), 7.08-7.12 (m, 1H), 7.30-7.35 (m, 2H), $7.42(\mathrm{~d}, J=2.8 \mathrm{~Hz}, 1 \mathrm{H}), 7.94(\mathrm{~d}, J=8.8 \mathrm{~Hz}, 1 \mathrm{H})$; ${ }^{13} \mathrm{C} \mathrm{NMR}\left(\mathrm{CDCl}_{3}\right) \delta 28.5,81.3,89.5,118.6,120.2,121.6,123.6,129.3,130.0,134.9,153.0$, $153.0,157.4$.

2-Iodo-4-phenoxyaniline. To a solution of $N$-(2-iodo-4-phenoxyphenyl)-2,2dimethylpropanamide $(0.82 \mathrm{~g}, 2.0 \mathrm{mmol})$ in $10 \mathrm{~mL}$ of $\mathrm{CH}_{2} \mathrm{Cl}_{2}$ was added dropwise $2.0 \mathrm{~mL}$ of TFA at $0{ }^{\circ} \mathrm{C}$ and the reaction was allowed to warm up to room temperature. The resulting colorless mixture was stirred at room temperature for $16 \mathrm{~h}$, diluted with $20 \mathrm{~mL}$ of $\mathrm{CH}_{2} \mathrm{Cl}_{2}$, washed with brine $(30 \mathrm{~mL})$, dried over $\mathrm{Na}_{2} \mathrm{SO}_{4}$, filtered and concentrated. The residue was purified by flash chromatography (5:1 hexane/EtOAc) to afford $0.56 \mathrm{~g}$ of the indicated compound (91\% yield) as a pale orange solid: $\mathrm{mp} 54-56{ }^{\circ} \mathrm{C} ;{ }^{1} \mathrm{H} \mathrm{NMR}\left(\mathrm{CDCl}_{3}\right) \delta 4.00(\mathrm{~s}$, 2H), $6.74(\mathrm{~d}, J=8.7 \mathrm{~Hz}, 1 \mathrm{H}), 6.88-6.91(\mathrm{~m}, 2 \mathrm{H}), 6.93-6.95(\mathrm{~m}, 1 \mathrm{H}), 7.01-7.07(\mathrm{~m}, 1 \mathrm{H}), 7.26-$ $7.32(\mathrm{~m}, 2 \mathrm{H}), 7.36(\mathrm{~d}, J=2.7 \mathrm{~Hz}, 1 \mathrm{H}) ;{ }^{13} \mathrm{C} \mathrm{NMR}\left(\mathrm{CDCl}_{3}\right) \delta 83.8,115.2,117.6,121.6,122.8$, $129.9,130.3,143.5,148.8,158.6$. 
4-Phenoxy-2-phenylaniline. To a $50 \mathrm{~mL}$ round-bottom flask was added $\mathrm{PdCl}_{2}\left(\mathrm{PPh}_{3}\right)_{2}$ (0.103 g, $0.147 \mathrm{mmol}), \mathrm{PhB}(\mathrm{OH})_{2}(0.358 \mathrm{~g}, 2.94 \mathrm{mmol}), \mathrm{K}_{2} \mathrm{CO}_{3}(0.406 \mathrm{~g}, 2.94 \mathrm{mmol}), 2-$ iodo-4-phenoxyaniline $(0.457 \mathrm{~g}, 1.47 \mathrm{mmol}), 15 \mathrm{~mL}$ of DMF and $3 \mathrm{~mL}$ of $\mathrm{H}_{2} \mathrm{O}$. The whole mixture was then stirred at room temperature for $5 \mathrm{~min}$, flushed with $\mathrm{Ar}$ and heated to $70{ }^{\circ} \mathrm{C}$ for $3 \mathrm{~h}$. The reaction was allowed to cool to room temperature, diluted with diethyl ether (30 $\mathrm{mL})$, washed with brine $(50 \mathrm{~mL})$, dried over $\mathrm{Na}_{2} \mathrm{SO}_{4}$, filtered and concentrated under reduced pressure. The residue was purified by flash chromatography (5:1 hexane/EtOAc) to afford $0.342 \mathrm{~g}$ of the indicated compound (88\% yield) as a yellow oil: ${ }^{1} \mathrm{H}$ NMR $\left(\mathrm{CDCl}_{3}\right) \delta 3.71$ (br $\mathrm{s}, 2 \mathrm{H}), 6.75-6.77(\mathrm{~m}, 1 \mathrm{H}), 6.87-6.90(\mathrm{~m}, 2 \mathrm{H}), 6.97-7.03(\mathrm{~m}, 3 \mathrm{H})$, 7.25-7.35 (m, 3H), 7.41$7.60(\mathrm{~m}, 4 \mathrm{H}) ;{ }^{13} \mathrm{C} \mathrm{NMR}\left(\mathrm{CDCl}_{3}\right) \delta 116.9,117.5,120.4,122.2,122.3,127.6,129.0,129.1$, $129.2,129.7,139.1,139.9,148.9,159.0$.

2-Iodo-5-phenoxybiphenyl (55). To a solution of 4-phenoxy-2-phenylaniline $(0.383 \mathrm{~g}$, $1.47 \mathrm{mmol})$ in DME (4 mL) was added dropwise $3 \mathrm{~mL}$ of water containing $0.6 \mathrm{~mL}$ of conc $\mathrm{H}_{2} \mathrm{SO}_{4}(95 \%)$. The resulting yellow mixture was cooled to $0{ }^{\circ} \mathrm{C}$ and a solution of $\mathrm{NaNO}_{2}$ $(0.152 \mathrm{~g}, 2.21 \mathrm{mmol})$ in water $(1 \mathrm{~mL})$ was added over $10 \mathrm{~min}$. The yellow reaction mixture was stirred at $0{ }^{\circ} \mathrm{C}$ for $20 \mathrm{~min}$ and a solution of $\mathrm{NaI}(1.10 \mathrm{~g}, 7.35 \mathrm{mmol})$ in water $(3 \mathrm{~mL})$ was added dropwise at $0{ }^{\circ} \mathrm{C}$. The reaction mixture turned black when the NaI solution was added. After $10 \mathrm{~min}$, the reaction was diluted with $\mathrm{Et}_{2} \mathrm{O}(30 \mathrm{~mL})$, and washed by satd $\mathrm{Na}_{2} \mathrm{~S}_{2} \mathrm{O}_{3}(30$ $\mathrm{mL})$, water $(30 \mathrm{~mL})$, and brine $(30 \mathrm{~mL})$. The organic layer was collected, dried over $\mathrm{Na}_{2} \mathrm{SO}_{4}$, filtered and concentrated under reduced pressure. The residue was purified by flash chromatography (30:1 hexane/EtOAc) to afford $0.44 \mathrm{~g}$ of the indicated compound $\mathbf{5 5}(81 \%$ yield) as a yellow solid: $\operatorname{mp} 68-70{ }^{\circ} \mathrm{C} ;{ }^{1} \mathrm{H} \mathrm{NMR}\left(\mathrm{CDCl}_{3}\right) \delta 6.73(\mathrm{dd}, J=3.0,8.8 \mathrm{~Hz}, 1 \mathrm{H})$, $6.97(\mathrm{~d}, J=2.8 \mathrm{~Hz}, 1 \mathrm{H}), 7.04-7.06(\mathrm{~m}, 2 \mathrm{H}), 7.11-7.15(\mathrm{~m}, 1 \mathrm{H}), 7.31-7.43(\mathrm{~m}, 7 \mathrm{H}), 7.85(\mathrm{~d}, J$ 
$=8.8 \mathrm{~Hz}, 1 \mathrm{H}) ;{ }^{13} \mathrm{C} \mathrm{NMR}\left(\mathrm{CDCl}_{3}\right) \delta 90.4,119.4,119.5,120.5,124.1,128.0,128.2,129.4$, 130.1, 140.6, 143.9, 148.2, 156.6, 158.0; IR $\left(\mathrm{CH}_{2} \mathrm{Cl}_{2}\right) 3056,2981,1583,1561,1490 \mathrm{~cm}^{-1}$; HRMS m/z 372.0019 (calcd for $\mathrm{C}_{18} \mathrm{H}_{13} \mathrm{IO}, 372.0011$ ).

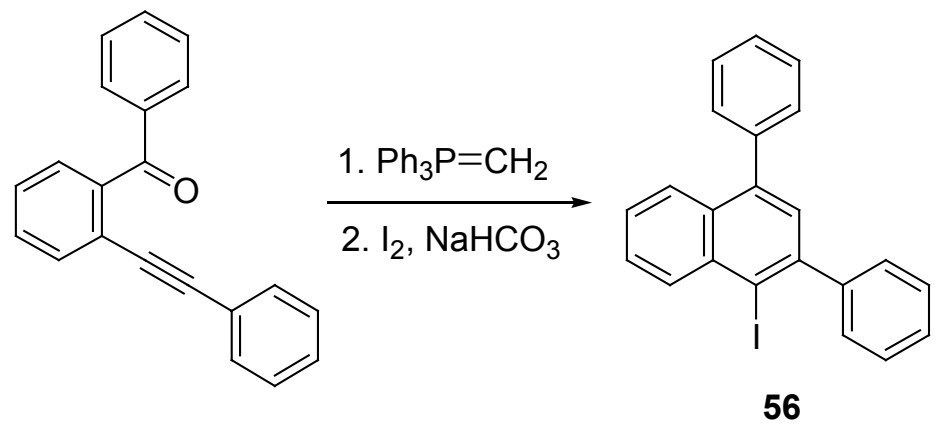

1-Iodo-2,4-diphenylnaphthalene (56). To a yellow suspension of $\mathrm{Ph}_{3} \mathrm{P}=\mathrm{CH}_{2}(1.5$ mmol) in THF $(8 \mathrm{~mL})$ [prepared by the reaction of $0.57 \mathrm{~g}$ of methyltriphenylphosphonium bromide (1.6 mmol) in $8 \mathrm{~mL}$ of THF and $0.6 \mathrm{~mL}$ of $n-\mathrm{BuLi}(2.5 \mathrm{M}$ in hexane, $1.5 \mathrm{mmol})$ at 0 ${ }^{\circ} \mathrm{C}$ for $30 \mathrm{~min}$ ] was added a solution of 2-(phenylethynyl)acetophenone $(1.0 \mathrm{mmol})$ in THF (3 $\mathrm{mL}$ ). After $1 \mathrm{~h}, \mathrm{TLC}$ analysis showed that the reaction was not complete and another 1.0 mmol of $\mathrm{Ph}_{3} \mathrm{P}=\mathrm{CH}_{2}$ in THF (5 mL) was added to the reaction mixture. The reaction reached completion in $10 \mathrm{~min}$. The solvent was removed under reduced pressure and $30 \mathrm{~mL}$ of hexane was added to the residue. After being stirred at $25^{\circ} \mathrm{C}$ for $20 \mathrm{~min}$, the mixture was filtered to remove the phosphonium salt. Removal of the solvent under reduced pressure afforded a colorless residue. The colorless residue was added to a stirred mixture of $\mathrm{NaHCO}_{3}(0.25 \mathrm{~g}, 3.0 \mathrm{mmol}), \mathrm{I}_{2}(1.54 \mathrm{~g}, 6.0 \mathrm{mmol})$ and $\mathrm{CH}_{3} \mathrm{CN}(15 \mathrm{~mL})$. The reaction was complete after $20 \mathrm{~min}$ at $25^{\circ} \mathrm{C}$. The reaction mixture was diluted with $\mathrm{Et}_{2} \mathrm{O}(30 \mathrm{~mL})$ and washed by satd aqueous $\mathrm{Na}_{2} \mathrm{~S}_{2} \mathrm{O}_{3}(30 \mathrm{~mL})$. The organic layer was collected, dried over $\mathrm{NaSO}_{4}$, filtered, and the solvent was removed under reduced pressure. The residue was purified by chromatograph (50:1 hexane/EtOAc) to afford $0.39 \mathrm{~g}$ of the indicated compound 
56 in a $97 \%$ yield as a yellow oil: ${ }^{1} \mathrm{H}$ NMR $\left(\mathrm{CDCl}_{3}\right) \delta$ 7.38-7.50 (m, $\left.12 \mathrm{H}\right), 7.58-7.63(\mathrm{~m}$, $1 \mathrm{H}), 7.88(\mathrm{~d}, J=8.1 \mathrm{~Hz}, 1 \mathrm{H}), 8.43(\mathrm{~d}, J=8.1 \mathrm{~Hz}, 1 \mathrm{H}) ;{ }^{13} \mathrm{C} \mathrm{NMR}\left(\mathrm{CDCl}_{3}\right) \delta 103.6,126.8$ $126.9,127.8,128.2,128.2,128.6,128.9,129.8,130.2,131.5,134.1,135.3,139.9,140.9$, 146.0, 146.2 (one sp ${ }^{2}$ carbon missing due to overlap); IR (neat) 3058, 3028, 2927, $1599 \mathrm{~cm}^{-1}$; HRMS $m / z 406.0225$ (calcd for $\mathrm{C}_{22} \mathrm{H}_{15} \mathrm{I}, 406.0218$ ).

Representative procedure for the palladium-catalyzed migration reactions. The appropriate aryl iodide $(0.25 \mathrm{mmol}), \mathrm{Pd}(\mathrm{OAc})_{2}(2.8 \mathrm{mg}, 0.0125 \mathrm{mmol}), 1,1-$ bis(diphenylphosphino)methane (dppm) $(4.8 \mathrm{mg}, 0.0125 \mathrm{mmol})$ and $\mathrm{CsO}_{2} \mathrm{CCMe}_{3}(\mathrm{CsPiv})$ $(0.117 \mathrm{~g}, 0.5 \mathrm{mmol})$ in DMF $(4 \mathrm{~mL})$ were stirred under $\mathrm{Ar}$ at $100{ }^{\circ} \mathrm{C}$ for the specified period of time. The reaction mixture was allowed to cool to room temperature, diluted with diethyl ether $(35 \mathrm{~mL})$ and washed with brine $(30 \mathrm{~mL})$. The aqueous layer was reextracted with diethyl ether $(15 \mathrm{~mL})$. The organic layers were combined, dried $\left(\mathrm{MgSO}_{4}\right)$, filtered, and the solvent removed under reduced pressure. The residue was purified by flash chromatography on silica gel.

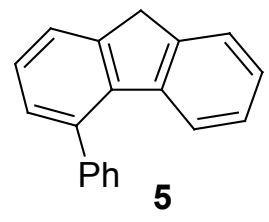

1-Phenyl-9H-fluorene (5). Compound 4 (92.5 mg, $0.25 \mathrm{mmol})$ was allowed to react under our standard reaction conditions at $110{ }^{\circ} \mathrm{C}$ for $3 \mathrm{~d}$. The reaction mixture was chromatographed using 30:1 hexane/EtOAc to afford $24.2 \mathrm{mg}(40 \%)$ of the indicated compound 2 as a colorless oil: ${ }^{1} \mathrm{H}$ NMR $\left(\mathrm{CDCl}_{3}\right) \delta$ $3.95(\mathrm{~s}, 2 \mathrm{H}), 6.94(\mathrm{~d}, J=7.6 \mathrm{~Hz}, 1 \mathrm{H}), 7.05(\mathrm{t}, J=7.6 \mathrm{~Hz}, 1 \mathrm{H}), 7.19-7.22(\mathrm{~m}, 2 \mathrm{H}), 7.33$ (t, $J=$ 7.6 Hz, 1H), 7.45-7.55 (m, 7H); ${ }^{13} \mathrm{C}$ NMR $\left(\mathrm{CDCl}_{3}\right) \delta 37.0,122.9,124.0,124.8,126.3,126.4$, $127.5,128.5,128.8,129.2,137.9,138.7,141.3,141.6,143.7,143.9$ (one $\mathrm{sp}^{2}$ carbon missing due to overlap); IR $\left(\mathrm{CH}_{2} \mathrm{Cl}_{2}\right) 3056,3025,1454,1417,1478 \mathrm{~cm}^{-1}$; HRMS $m / z 242.1101$ (calcd for $\left.\mathrm{C}_{19} \mathrm{H}_{14}, 242.1096\right)$. 


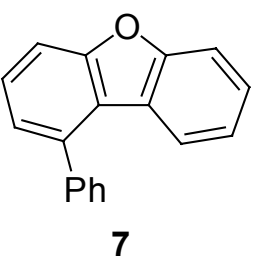

1-Phenyldibenzofuran (7). Compound 6 (93.0 mg, $0.25 \mathrm{mmol})$ or compound $\mathbf{5 5}$ (93.0 $\mathrm{mg}, 0.25 \mathrm{mmol})$ was allowed to react under our standard reaction conditions for $1 \mathrm{~d}$. The reaction mixtures were chromatographed using 30:1 hexane/EtOAc to afford $54.4 \mathrm{mg}$ (89\%) (entry 2, Table 2) or $54.0 \mathrm{mg}(88 \%)$ (entry 8 , Table 2 ) of the indicated compound 7 , respectively, as a white solid: mp 62-63 ${ }^{\circ} \mathrm{C}\left(\mathrm{lit}^{13} \mathrm{mp} 63-64{ }^{\circ} \mathrm{C}\right) ;{ }^{1} \mathrm{H}$ NMR $\left(\mathrm{CDCl}_{3}\right) \delta$ 7.10-7.14 (m, $\left.1 \mathrm{H}\right), 7.24-7.26(\mathrm{~m}, 1 \mathrm{H})$, 7.37-7.42 (m, 1H), 7.46-7.64 (m, 9H); ${ }^{13} \mathrm{C}$ NMR $\left(\mathrm{CDCl}_{3}\right) \delta 110.5,111.6,121.8,122.3,122.5$, $123.9,124.0,127.1,127.1,127.9,128.6,129.0,138.0,140.0,156.4,156.5$. The other spectral properties were identical to those previously reported. ${ }^{13}$

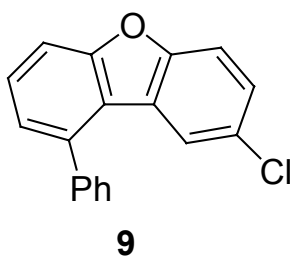

7-Chloro-1-phenyldibenzofuran (9). Compound 8 (0.101 g, 0.25 mmol) was allowed to react under our standard reaction conditions for 1 d. The reaction mixture was chromatographed using 50:1 hexanes/ethyl acetate to afford $57.1 \mathrm{mg}(82 \%)$ of the indicated compound 9 as a colorless oil: ${ }^{1} \mathrm{H}$ NMR $\left(\mathrm{CDCl}_{3}\right) \delta 7.25(\mathrm{dd}, J=6.8,1.2 \mathrm{~Hz}, 1 \mathrm{H}), 7.34(\mathrm{dd}, J=8.4,2.4 \mathrm{~Hz}, 1 \mathrm{H}), 7.45-7.60$ (m, 9H); ${ }^{13} \mathrm{C} \mathrm{NMR}\left(\mathrm{CDCl}_{3}\right) \delta 110.7,112.5,121.0,122.1,124.3,125.3,127.1,127.7,127.8,128.3$, 128.8, 128.9, 138.2, 139.4, 154.7, 157.1; IR $\left(\mathrm{CH}_{2} \mathrm{Cl}_{2}\right) 3061,3032,1444,1400,1199,1243$ $\mathrm{cm}^{-1}$; HRMS m/z 278.0501 (calcd for $\mathrm{C}_{18} \mathrm{H}_{11} \mathrm{ClO}, 278.0498$ ).

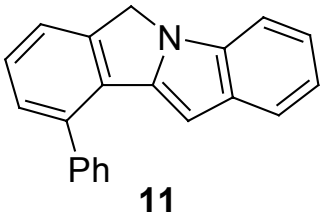

10-Phenyl-6H-isoindolo[2,1-a]indole (11). Compound 10 (0.102

$\mathrm{g}, 0.25 \mathrm{mmol}$ ) was allowed to react under our standard reaction conditions for $1 \mathrm{~d}$. The reaction mixture was chromatographed using 12:1 hexanes/ethyl acetate to afford $49.2 \mathrm{mg}(70 \%)$ of the indicated compound $\mathbf{1 1}$ as a white solid: $\mathrm{mp} 139-140{ }^{\circ} \mathrm{C} ;{ }^{1} \mathrm{H} \mathrm{NMR}\left(\mathrm{CDCl}_{3}\right) \delta 5.08(\mathrm{~s}, 2 \mathrm{H}), 6.16(\mathrm{~s}, 1 \mathrm{H}), 7.03-7.07(\mathrm{~m}, 1 \mathrm{H})$, 7.14-7.18 (m, 1H), 7.32-7.54 (m, 8H), 7.64-7.66 (m, 2H); ${ }^{13} \mathrm{C} \mathrm{NMR}\left(\mathrm{CDCl}_{3}\right)$ \& 48.2, 94.3, 
109.1, 119.7, 121.7, 122.4, 127.3, 128.0, 128.5, 128.8, 129.3, 131.0, 132.4, 133.7, 137.0, 139.9, 142.5, 143.2 (one sp ${ }^{2}$ carbon missing due to overlap); IR $\left(\mathrm{CH}_{2} \mathrm{Cl}_{2}\right) 3053,2916,2850$, 1471, 1551, $1446 \mathrm{~cm}^{-1}$; HRMS $\mathrm{m} / z 281.1210$ (calcd for $\mathrm{C}_{21} \mathrm{H}_{15} \mathrm{~N}, 281.1204$ ).

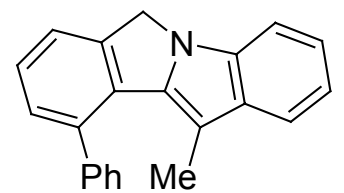

13

2-Methyl-10-phenyl-6H-isoindolo[2,1-a]indole (13). Compound

$12(0.106 \mathrm{~g}, 0.25 \mathrm{mmol})$ was allowed to react under our standard reaction conditions for $1 \mathrm{~d}$. The reaction mixture was chromatographed using 12:1 hexanes/ethyl acetate to afford $52.4 \mathrm{mg}(71 \%)$ of the indicated compound $\mathbf{1 3}$ as a white solid: $\mathrm{mp} 143-145{ }^{\circ} \mathrm{C}$ (decomposes); ${ }^{1} \mathrm{H}$ NMR $\left(\mathrm{CDCl}_{3}\right) \delta 1.41$ (s, 3H), $5.06(\mathrm{~s}, 2 \mathrm{H})$, 7.03-7.07 (m, 1H), 7.16-7.20 (m, 1H), 7.23-7.31 (m, 3H), 7.40-7.50 (m, 7H); ${ }^{13} \mathrm{C}$ NMR $\left(\mathrm{CDCl}_{3}\right) \delta 9.5,48.1,104.2,109.0,119.1,120.0,122.0,122.4,126.5,127.9,128.7,129.9$, 130.2, 132.6, 133.8, 134.0, 137.0, 140.0, 142.6, 142.8; $\mathrm{IR}\left(\mathrm{CH}_{2} \mathrm{Cl}_{2}\right) 3048,2976,2853,1469$, 2976, 2853, 1469, $1411 \mathrm{~cm}^{-1}$; HRMS $m / z 295.1369$ (calcd for $\mathrm{C}_{22} \mathrm{H}_{17} \mathrm{~N}, 295.1361$ ).<smiles>c1ccc(-c2cccc3c2-c2ccccc2OC3)cc1</smiles>

15

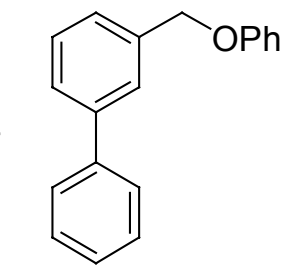

16
10-Phenyl-6H-benzo $[c]$ chromene (15) and phenyl 3-phenylbenzyl ether (16). Compound 14 (96.5 mg, $0.25 \mathrm{mmol}$ ) was allowed to react under our standard reaction conditions at $120{ }^{\circ} \mathrm{C}$ for $2 \mathrm{~d}$. The

reaction mixture was chromatographed using 50:1 hexanes/ethyl acetate to afford $47.8 \mathrm{mg}$ (75\%) of a 60:40 inseparable mixture of compounds 15 and $\mathbf{1 6}$ respectively. Major isomer 15: ${ }^{1} \mathrm{H}$ NMR $\left(\mathrm{CDCl}_{3}\right) \delta 5.02(\mathrm{~s}, 2 \mathrm{H})$ as a characteristic peak; HRMS $m / z 258.1050$ (calcd for $\left.\mathrm{C}_{19} \mathrm{H}_{14} \mathrm{O}, 258.1045\right)$. Minor isomer 16: ${ }^{1} \mathrm{H}$ NMR $\left(\mathrm{CDCl}_{3}\right) \delta 5.11(\mathrm{~s}, 2 \mathrm{H})$ as a characteristic peak; HRMS $m / z 260.1206$ (calcd for $\mathrm{C}_{19} \mathrm{H}_{16} \mathrm{O}, 260.1201$ ). Mixture: ${ }^{13} \mathrm{C}_{\mathrm{NMR}}\left(\mathrm{CDCl}_{3}\right) \delta$ $69.9,70.2,115.1,117.6,121.3,121.3,123.6,124.1,126.6,126.7,127.1,127.4,127.4,127.5$, $127.5,127.7,128.4,128.9,128.9,128.9,129.1,129.1,129.3,129.4,129.4,129.8,132.0$, 
135.5, 137.8, 139.3, 141.2, 141.9, 142.5, 156.6, 159.0; IR (neat) 3058, 3029, 1599, 1495, $1453,1243 \mathrm{~cm}^{-1}$.

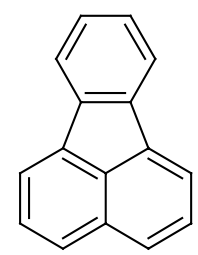

18

Fluoranthene (18). Compound 17 (82.5 mg, $0.25 \mathrm{mmol})$ was allowed to react under our standard reaction conditions at $110{ }^{\circ} \mathrm{C}$ for $1 \mathrm{~d}$. The reaction mixture was chromatographed using 50:1 hexane/EtOAc to afford $41.0 \mathrm{mg}$ (81 $\%)$ of the indicated compound 6 as a white solid: $\mathrm{mp} 107-108{ }^{\circ} \mathrm{C}\left(\mathrm{lit}^{14} \mathrm{mp} 106-\right.$ $108^{\circ} \mathrm{C}$ ). The other spectral properties were identical to those previously reported. ${ }^{15}$<smiles></smiles>

Benzo[e]acephenanthrylene (21). Compound $\mathbf{2 0}^{1}$ ( $95.0 \mathrm{mg}, 0.25$ mmol) was allowed to react under our standard reaction conditions at 110 ${ }^{\circ} \mathrm{C}$ for $2 \mathrm{~d}$. The reaction mixture was chromatographed using 50:1 hexane/EtOAc to afford $49.2 \mathrm{mg}$ (78 \%) of the indicated compound 8 as a white solid: $\mathrm{mp}$ $166-167{ }^{\circ} \mathrm{C}\left(\mathrm{lit}^{16} \mathrm{mp} 165-166{ }^{\circ} \mathrm{C}\right)$. The other spectral properties were identical to those previously reported. ${ }^{17}$<smiles>COc1ccc2c3ccccc3c3ccccc3c2c1</smiles>

5-Methoxybenzo[e]acephenanthrylene (23). Compound 22 $(0.103 \mathrm{~g}, 0.25 \mathrm{mmol})$ was allowed to react under our standard reaction conditions at $110{ }^{\circ} \mathrm{C}$ for $2 \mathrm{~d}$. The reaction mixture was chromatographed using 30:1 hexanes/ethyl acetate to afford 50.1 mg (71 \%) of the indicated compound 23 as a white solid: $\mathrm{mp} 188-189{ }^{\circ} \mathrm{C}\left(1 \mathrm{it}{ }^{17} \mathrm{mp} 189-190{ }^{\circ} \mathrm{C}\right)$. The other spectral properties were identical to those previously reported. ${ }^{17}$<smiles>CCOC(=O)c1ccc2c3ccccc3c3ccccc3c2c1</smiles>

Ethyl benzo[e]acephenanthrylene-5-carboxylate (25). Compound 24 ( $0.113 \mathrm{~g}, 0.25 \mathrm{mmol})$ was allowed to react under our standard reaction conditions at $110{ }^{\circ} \mathrm{C}$ for $2 \mathrm{~d}$. The reaction 
mixture was chromatographed using 9:1 hexanes/ethyl acetate to afford $40.5 \mathrm{mg}(50 \%)$ of the indicated compound 25 as a white solid: $\operatorname{mp} 153-154{ }^{\circ} \mathrm{C} ;{ }^{1} \mathrm{H} \mathrm{NMR}\left(\mathrm{CDCl}_{3}\right) \delta 1.46(\mathrm{t}, J=$ $7.2 \mathrm{~Hz}, 3 \mathrm{H}), 4.45$ (q, $J=7.2 \mathrm{~Hz}, 2 \mathrm{H}), 7.63-7.65(\mathrm{~m}, 1 \mathrm{H}), 7.68-7.70(\mathrm{~m}, 1 \mathrm{H}), 7.74-7.78(\mathrm{~m}$, 1H), 7.98-8.04 (m, 3H), 8.09 (dd, $J=7.6,1.6 \mathrm{~Hz}, 1 \mathrm{H}), 8.24(\mathrm{~s}, 1 \mathrm{H}), 8.45(\mathrm{~d}, J=8.0 \mathrm{~Hz}, 1 \mathrm{H})$, $8.54(\mathrm{~d}, J=0.8 \mathrm{~Hz}, 1 \mathrm{H}), 8.64(\mathrm{~d}, J=8.0 \mathrm{~Hz}, 1 \mathrm{H}) ;{ }^{13} \mathrm{C} \mathrm{NMR}\left(\mathrm{CDCl}_{3}\right) \delta 14.5,61.2,120.1$, $121.5,122.1,122.5,123.2,123.3,127.0,127.6,127.7,128.5,129.0,129.9,130.6,131.1$, 132.4, 133.8, 134.0, 136.2, 140.7, 142.6, 166.9; IR $\left(\mathrm{CH}_{2} \mathrm{Cl}_{2}\right) 2979,1710,1240,1290 \mathrm{~cm}^{-1}$; HRMS $m / z 324.1157$ (calcd for $\mathrm{C}_{23} \mathrm{H}_{16} \mathrm{O}_{2}, 324.1150$ ).

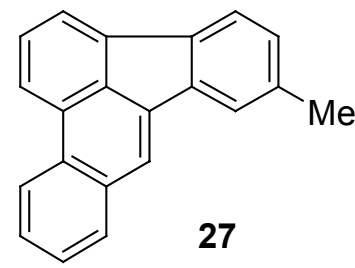

6-Methylbenzo[e]acephenanthrylene (27). Compound 26 (98.5

chromatographed using 50:1 hexane/EtOAc to afford $37.2 \mathrm{mg}(56 \%)$ of the indicated compound 27 as a white solid: $\operatorname{mp} 149-151{ }^{\circ} \mathrm{C} ;{ }^{1} \mathrm{H}$ NMR $\left(\mathrm{CDCl}_{3}\right) \delta 2.50(\mathrm{~s}, 3 \mathrm{H}), 7.22(\mathrm{~d}, J$ $=7.6 \mathrm{~Hz}, 1 \mathrm{H}), 7.59-7.80(\mathrm{~m}, 5 \mathrm{H}), 7.91(\mathrm{~d}, J=7.2 \mathrm{~Hz}, 1 \mathrm{H}), 8.01-8.02(\mathrm{~m}, 1 \mathrm{H}), 8.17(\mathrm{~s}, 1 \mathrm{H})$, $8.40(\mathrm{~d}, J=8.0 \mathrm{~Hz}, 1 \mathrm{H}), 8.63(\mathrm{~d}, J=8.4 \mathrm{~Hz}, 1 \mathrm{H}) ;{ }^{13} \mathrm{C} \mathrm{NMR}\left(\mathrm{CDCl}_{3}\right) \delta 21.9,119.2,121.2$, $121.3,121.3,122.8,123.2,126.8,127.0,127.6,128.3,129.0,130.2,130.8,132.4,134.1$, 135.3, 137.2, 137.5, 138.2, 138.9; IR $\left(\mathrm{CH}_{2} \mathrm{Cl}_{2}\right) 2921,2852,1460,1600,1374 \mathrm{~cm}^{-1}$; HRMS $m / z 266.1099$ (calcd for $\mathrm{C}_{21} \mathrm{H}_{14}, 266.1096$ ).

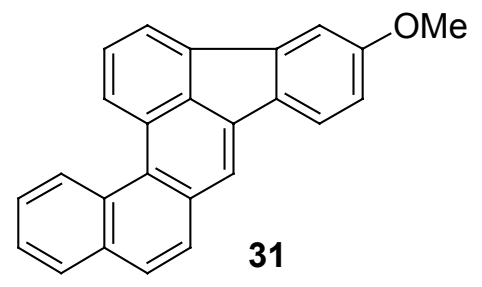

\section{0-Methoxydibenz[e,l] acephenanthrylene (31).}

Compound 30 (0.115 g, $0.25 \mathrm{mmol})$ was allowed to react under our standard reaction conditions at $110^{\circ} \mathrm{C}$ for $2 \mathrm{~d}$. The reaction mixture was chromatographed using 50:1 hexanes/ethyl acetate to afford $54.0 \mathrm{mg}(65 \%)$ of the indicated compound 31 as a white solid: $\mathrm{mp} 178-179{ }^{\circ} \mathrm{C} ;{ }^{1} \mathrm{H} \mathrm{NMR}\left(\mathrm{CDCl}_{3}\right) \delta 3.95(\mathrm{~s}$, 
$3 \mathrm{H}), 6.93(\mathrm{dd}, J=8.1,2.4 \mathrm{~Hz}, 1 \mathrm{H}), 7.46(\mathrm{~d}, J=2.1 \mathrm{~Hz}, 1 \mathrm{H}), 7.60-7.66(\mathrm{~m}, 1 \mathrm{H}), 7.70-8.03(\mathrm{~m}$, $7 \mathrm{H}), 8.11(\mathrm{~s}, 1 \mathrm{H}), 8.98(\mathrm{~d}, J=8.4 \mathrm{~Hz}, 1 \mathrm{H}), 9.19(\mathrm{~d}, J=8.7 \mathrm{~Hz}, 1 \mathrm{H}) ;{ }^{13} \mathrm{C} \mathrm{NMR}\left(\mathrm{CDCl}_{3}\right) \delta$ $55.9,107.4,113.4,119.6,121.0,122.8,122.8,126.0,126.8,127.3,127.5,127.8,128.3,128.4$, 128.6, 128.7, 129.0, 131.5, 131.5, 133.8, 133.8, 136.1, 137.4, 142.6, 160.6; IR $\left(\mathrm{CH}_{2} \mathrm{Cl}_{2}\right) 2921$, 2849, 1608, 1461, 1285, $1213 \mathrm{~cm}^{-1}$; HRMS m/z 332.1209 (calcd for $\mathrm{C}_{25} \mathrm{H}_{16} \mathrm{O}, 332.1201$ ).

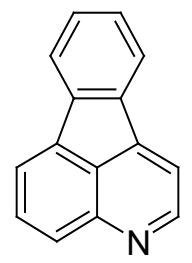

35

Indeno[1,2,3-de]quinoline (35). Compound 34 (82.8 mg, $0.25 \mathrm{mmol}$ ) was allowed to react under our standard reaction conditions at $110{ }^{\circ} \mathrm{C}$ for $2.5 \mathrm{~d}$. The reaction mixture was chromatographed using 3:2 hexanes/ethyl acetate to afford $27.4 \mathrm{mg}(54 \%)$ of the indicated compound 35 as a white solid: $\mathrm{mp} 100-101{ }^{\circ} \mathrm{C}$ $\left(\mathrm{lit}^{18} \mathrm{mp} 102-103{ }^{\circ} \mathrm{C}\right) ;{ }^{1} \mathrm{H}$ NMR $\left(\mathrm{CDCl}_{3}\right) \delta$ 7.35-7.51 (m, 2H), 7.72-7.77 (m, 2H), 7.84-7.91 (m, 3H), $7.99(\mathrm{~d}, J=8.4 \mathrm{~Hz}, 1 \mathrm{H}), 9.07(\mathrm{~d}, J=4.2 \mathrm{~Hz}, 1 \mathrm{H}) ;{ }^{13} \mathrm{C} \mathrm{NMR}\left(\mathrm{CDCl}_{3}\right) \delta$ 114.4, 121.0, $122.2,123.7,128.2,128.4,130.4,131.7,135.4,138.2,138.2,140.5,145.1,145.7,152.9$.

The other spectral properties were identical to those previously reported. ${ }^{19}$

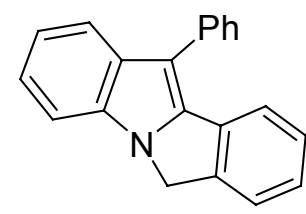

41

11-Phenyl-6H-isoindolo[2,1-a]indole (41). Compound 40 (103 mg, $0.25 \mathrm{mmol}$ ) was allowed to react under our standard reaction conditions for $1 \mathrm{~d}$ affording a $92 \%$ yield of the indicated compound 41 , which is

unstable on silica gel, as determined by ${ }^{1} \mathrm{H}$ NMR spectroscopy. To obtained pure compound 41, the crude product was recrystallized (hexane/EtOAc) to afford a pale purple solid: $\mathrm{mp}$ $148-151{ }^{\circ} \mathrm{C} ;{ }^{1} \mathrm{H}$ NMR (DMSO- $\left.d_{6}\right) \delta 5.27(\mathrm{~s}, 2 \mathrm{H}), 7.09-7.13(\mathrm{~m}, 1 \mathrm{H}), 7.21-7.25(\mathrm{~m}, 1 \mathrm{H}), 7.36-$ $7.39(\mathrm{~m}, 3 \mathrm{H}), 7.51-7.58(\mathrm{~m}, 3 \mathrm{H})$, 7.63-7.65 (m, 1H), 7.68-7.70 (m, 3H), 7.74-7.76 (m, 1H);

${ }^{13}$ C NMR (DMSO- $\left.d_{6}\right) \delta 48.2,108.0,110.2,119.5,120.0,120.2,122.0,124.2,126.2,127.6$, 128.0, 128.7, 128.9, 130.4, 131.9, 133.5, 134.4, 139.3, 142.7; IR $\left(\mathrm{CH}_{2} \mathrm{Cl}_{2}\right) 3053,2985,1616$, 1603, $1497 \mathrm{~cm}^{-1}$; HRMS $m / z 281.1209$ (calcd for $\mathrm{C}_{21} \mathrm{H}_{15} \mathrm{~N}, 281.1205$ ). 


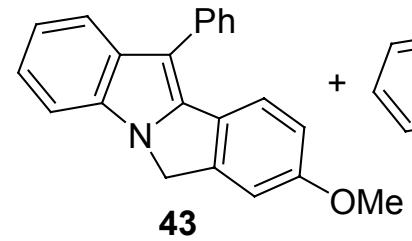

43

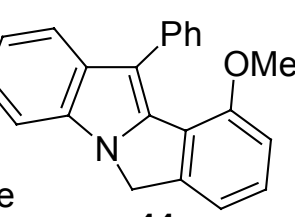

44

8-Methoxy-11-phenyl-6H-isoindolo[2,1a] indole (43) and 10-methoxy-11-phenyl-6Hisoindolo[2,1-a]indole (44). Compound 42 $(0.110 \mathrm{~g}, 0.25 \mathrm{mmol})$ was allowed to react under our standard reaction conditions for $12 \mathrm{~h}$. The reaction mixture was chromatographed using 9:1 hexane/EtOAc to afford $61 \mathrm{mg}$ (78\%) of the compound 43 as a yellow solid and $9 \mathrm{mg}(12 \%)$ of the compound 44. Compound 43: mp 196-198 ${ }^{\circ} \mathrm{C} ;{ }^{1} \mathrm{H}$ NMR (DMSO-d $\left.d_{6}\right) \delta 3.83$ (s, 3H), $5.23(\mathrm{~s}, 2 \mathrm{H}), 6.97$ (d, $J=8.4 \mathrm{~Hz}, 1 \mathrm{H}$ ), 7.07-7.10 (m, 1H), 7.17-7.21 (m, 1H), 7.27 (s, 1H), 7.34-7.37 (m, 1H), $7.48(\mathrm{~d}, J=8.4 \mathrm{~Hz}$ 1H), 7.53-7.57 (m, 2H), 7.66-7.68 (m, 4H); ${ }^{13} \mathrm{C}$ NMR (DMSO- $\left.d_{6}\right) \delta$ 48.4, 55.8, 108.1, 109.3, $109.8,113.7,120.0,120.3,121.9,122.1,126.0,126.2,128.9,129.3,131.6,134.1,135.4$, 140.3, 144.2, 159.7; IR $\left(\mathrm{CH}_{2} \mathrm{Cl}_{2}\right) 3051,1686,1450 \mathrm{~cm}^{-1}$; HRMS m/z 311.1316 (calcd for $\left.\mathrm{C}_{22} \mathrm{H}_{17} \mathrm{ON}, 311.1310\right)$.

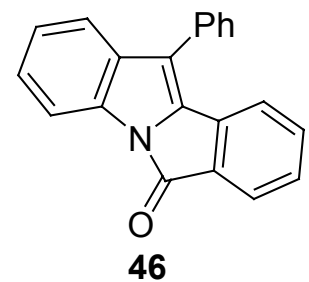

11-Phenyl-6H-isoindolo[2,1-a]indol-6-one (46). Compound 45 $(0.106 \mathrm{~g}, 0.25 \mathrm{mmol})$ was allowed to react under our standard reaction conditions for $1 \mathrm{~d}$. The reaction mixture was chromatographed using 10:1 hexane/EtOAc to afford $24 \mathrm{mg}(33 \%)$ of the indicated compound

46 as a yellow solid: $\mathrm{mp} 222-223{ }^{\circ} \mathrm{C} ;{ }^{1} \mathrm{H}$ NMR $\left(\mathrm{CDCl}_{3}\right) \delta$ 7.17-7.21 (m, $\left.1 \mathrm{H}\right), 7.31-7.36(\mathrm{~m}$, 2H), 7.40-7.44 (m, 1H), 7.45-7.49 (m, 1H), 7.54-7.60 (m, 4H), 7.70-7.72 (m, 2H), $7.79(\mathrm{~d}, J$ $=7.6 \mathrm{~Hz}, 1 \mathrm{H}), 7.97(\mathrm{~d}, J=7.6 \mathrm{~Hz}, 1 \mathrm{H}) ;{ }^{13} \mathrm{C} \mathrm{NMR}\left(\mathrm{CDCl}_{3}\right) \delta 113.8,120.8,121.4,121.5$, $124.3,125.6,127.0,128.6,129.0,129.2,129.3,132.4,133.9,134.0,134.1,134.2,134.4$, 134.9, 162.8; IR $\left(\mathrm{CH}_{2} \mathrm{Cl}_{2}\right)$ 3053, 2987, 1731, $1264 \mathrm{~cm}^{-1} ; \mathrm{HRMS} \mathrm{m} / \mathrm{z} 295.1003$ (calcd for $\left.\mathrm{C}_{21} \mathrm{H}_{13} \mathrm{ON}, 295.0997\right)$. 


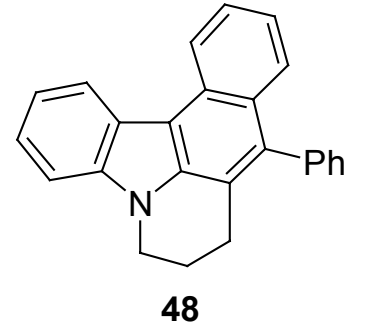

\section{9-Phenyl-7,8-dihydro-6H-benzo[c]pyrido[1,2,3-lm] carbazole}

(48). Compound 47 (116 $\mathrm{mg}, 0.25 \mathrm{mmol})$ was allowed to react under our standard reaction conditions for $12 \mathrm{~h}$. The reaction mixture was chromatographed using 20:1 hexane/EtOAc to afford $54 \mathrm{mg}(65 \%)$ of the indicated compound 48 as a yellow solid: $\operatorname{mp} 239-241{ }^{\circ} \mathrm{C} ;{ }^{1} \mathrm{H}$ NMR $\left(\mathrm{CDCl}_{3}\right) \delta 2.21-2.29$ (m, 2H), $2.87(\mathrm{t}, J=6.0 \mathrm{~Hz}, 2 \mathrm{H}), 4.31(\mathrm{t}, J=5.7 \mathrm{~Hz}, 2 \mathrm{H}), 7.28-7.34(\mathrm{~m}, 1 \mathrm{H}), 7.35-7.55(\mathrm{~m}$, $8 \mathrm{H}), 7.61-7.65(\mathrm{~m}, 2 \mathrm{H}), 8.58(\mathrm{~d}, J=7.8 \mathrm{~Hz}, 1 \mathrm{H}), 8.74-8.77(\mathrm{~m}, 1 \mathrm{H}) ;{ }^{13} \mathrm{C} \mathrm{NMR}\left(\mathrm{CDCl}_{3}\right) \delta$ $22.8,24.8,41.3,109.1,112.5,119.9,121.1,122.3,122.6,123.2,123.7,123.9,125.9,127.4$, $127.9,128.5,129.1,129.2,130.8,135.3,135.7,139.1,139.2 ; \mathrm{IR}\left(\mathrm{CH}_{2} \mathrm{Cl}_{2}\right)$ 3053, 2986, 1421 , $1265 \mathrm{~cm}^{-1}$; HRMS m/z 333.1523 (calcd for $\mathrm{C}_{25} \mathrm{H}_{19} \mathrm{~N}, 333.1518$ ). Anal. Calcd for $\mathrm{C}_{25} \mathrm{H}_{19} \mathrm{~N}$ : C, 90.06; H, 5.74; N, 4.20. Found: C, 90.27; H, 5.44; N, 4.17.

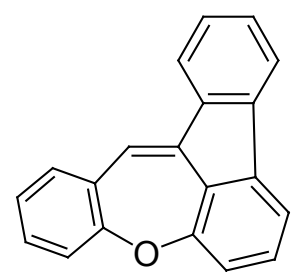

50

Benzo[f]fluoreno[1,9-bc]oxepine (50). Compound $49(99.1 \mathrm{mg}, 0.25$ mmol) was allowed to react under our standard reaction conditions at 110 ${ }^{\circ} \mathrm{C}$ for $2 \mathrm{~d}$. The reaction mixture was chromatographed using 18:1 hexanes/ethyl acetate to afford $53.6 \mathrm{mg}(80 \%)$ of the indicated compound

50 as a white solid: $\operatorname{mp~} 106-107{ }^{\circ} \mathrm{C} ;{ }^{1} \mathrm{H}$ NMR $\left(\mathrm{CDCl}_{3}\right) \delta 6.69(\mathrm{dd}, J=7.6,0.8 \mathrm{~Hz}, 1 \mathrm{H}), 6.83$ (s, 1H), 6.93-6.95 (m, 1H), 6.97-6.99 (m, 1H), 7.05-7.07 (m, 1H), 7.16-7.30 (m, 5H), 7.58$7.59(\mathrm{~m}, 1 \mathrm{H}), 7.62-7.64(\mathrm{~m}, 1 \mathrm{H}) ;{ }^{13} \mathrm{C} \mathrm{NMR}\left(\mathrm{CDCl}_{3}\right) \delta 115.4,117.2,120.4,120.6,122.3$, $124.8,126.0,127.2,128.3,128.7,129.1,131.3,131.4,132.4,137.1,137.6,139.9,141.0$, 154.8, 155.6; IR $\left(\mathrm{CH}_{2} \mathrm{Cl}_{2}\right)$ 3050, 1580, 1238, 1450, $1426 \mathrm{~cm}^{-1}$; HRMS m/z 268.0892 (calcd for $\left.\mathrm{C}_{20} \mathrm{H}_{12} \mathrm{O}, 268.0888\right)$. 


\section{References}

1. (a) Campo, M. A.; Larock, R. C. Org. Lett. 2000, 2, 3675. (b) Campo, M. A.; Larock, R. C. J. Org. Chem. 2002, 67, 5616.

2. Burton, H.; Praill, P. F. G. J. Chem. Soc. 1953, 827.

3. Hart, H.; Harada, K.; Du, C. J. Org. Chem. 1985, 50, 3104.

4. $\quad$ Evans, A. E.; Katz, J. L.; West, T. R. Tetrahedron Lett. 1998, 39, 2937.

5. John, J. A.; Tour, J. M. Tetrahedron 1997, 53, 15515.

6. Appelberg, U.; Mohell, N.; Hacksell, U. Bioorg. Med. Chem. Lett. 1996, 6, 415.

7. Yao, T.; Campo, M. A.; Larock, R. C. Org. Lett. 2004, 6, 2677.

8. Inoue, J.; Cui, Y.-S.; Sakai, O.; Nakamura, Y.; Kogiso, H.; Kador, P. F. Bioorg. Chem. 2000, 8, 2167.

9. Fiumana, A.; Jones, K. Chem. Commun. 1999, 1761.

10. Gibson, S. E.; Guillo, N.; Middleton, R. J.; Thuilliez, A.; Tozer, M. J. J. Chem. Soc., Perkin Trans. 1 1997, 447.

11. Larock, R. C.; Yum, E. K.; Doty, M. J.; Sham, K. C. J. Org. Chem. 1995, 60, 3270.

12. Kundu, N. G.; Khan, M. W. Tetrahedron 2000, 56, 4777.

13. McCall, E. B.; Neale, A. J.; Rawlings, T. J. J. Chem. Soc. 1962, 4900.

14. Badger, G. M.; Donnelly, J. K.; Spotswood, T. M. Aust. J. Chem. 1964, 17, 1147.

15. Yu, C.; Levy, G. C. J. Am. Chem. Soc. 1984, 106, 6533.

16. Badger, G. M.; Novotny, J. Aust. J. Chem. 1963, 16, 623.

17. Rice, J. E.; Cai, Z.-W. J. Org. Chem. 1993, 58, 1415.

18. Koelsch, S. J. Org. Chem. 1953, 18, 1516.

19. Dalgaard, M. J. Am. Chem. Soc. 1978, 100, 6887. 


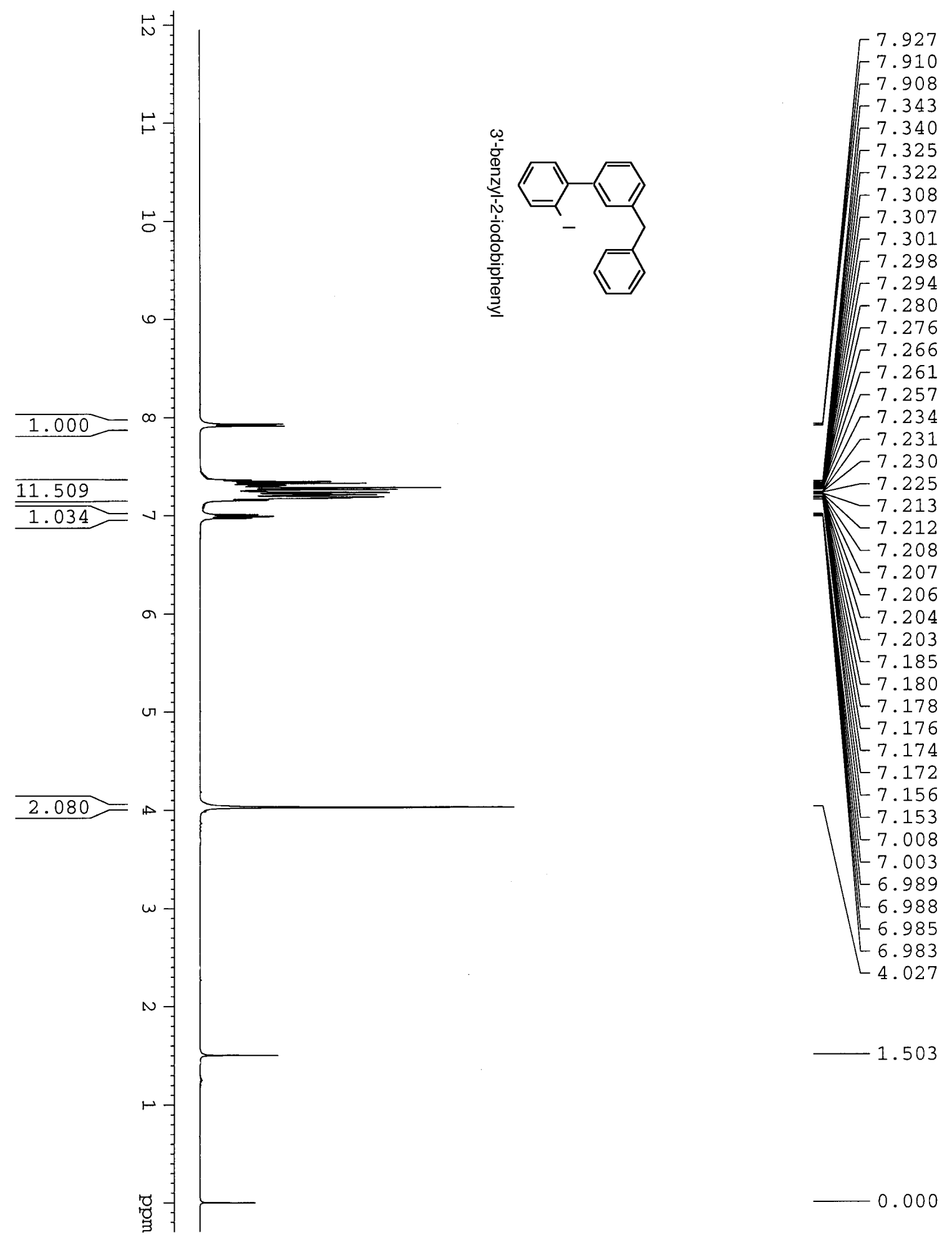



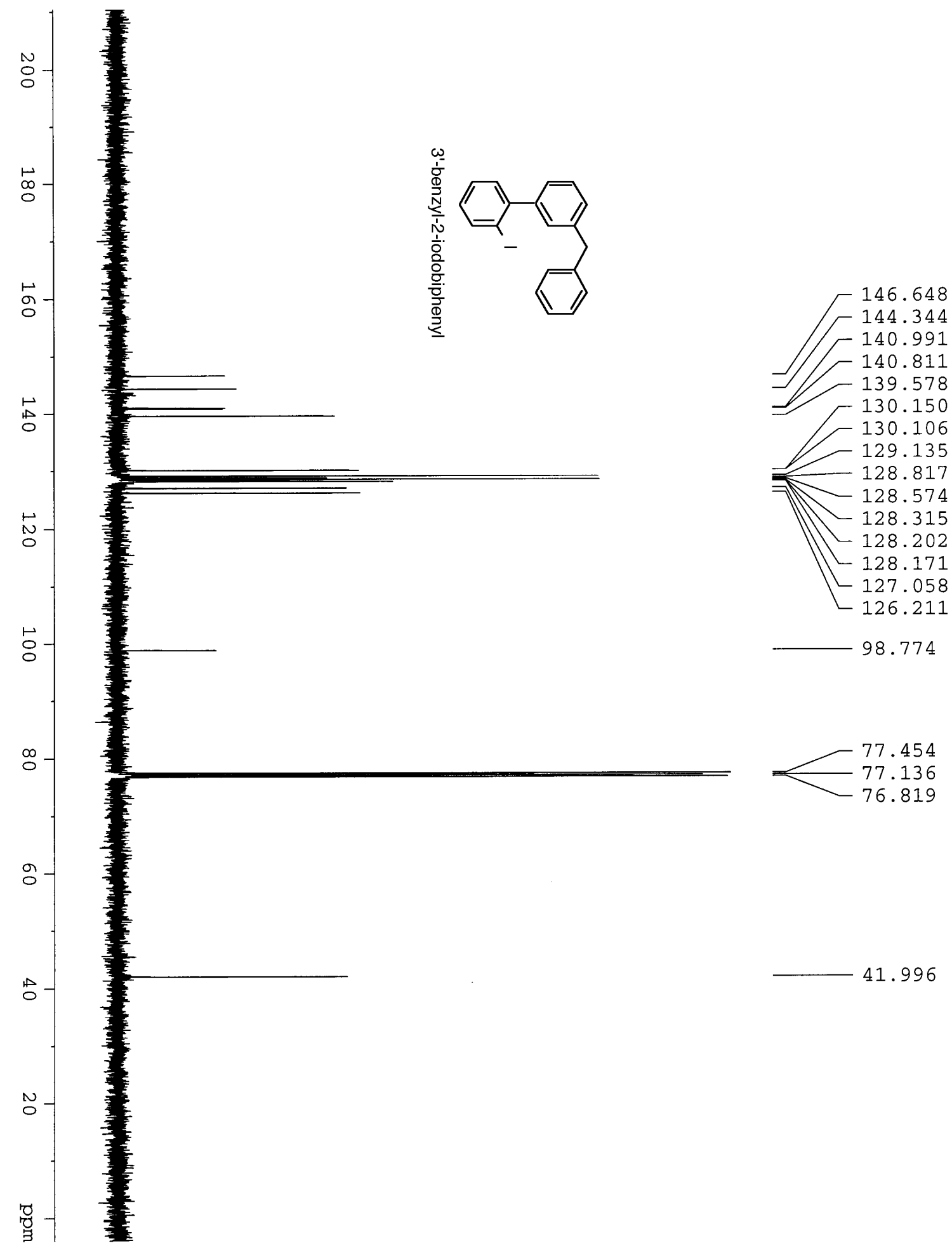

41.996 

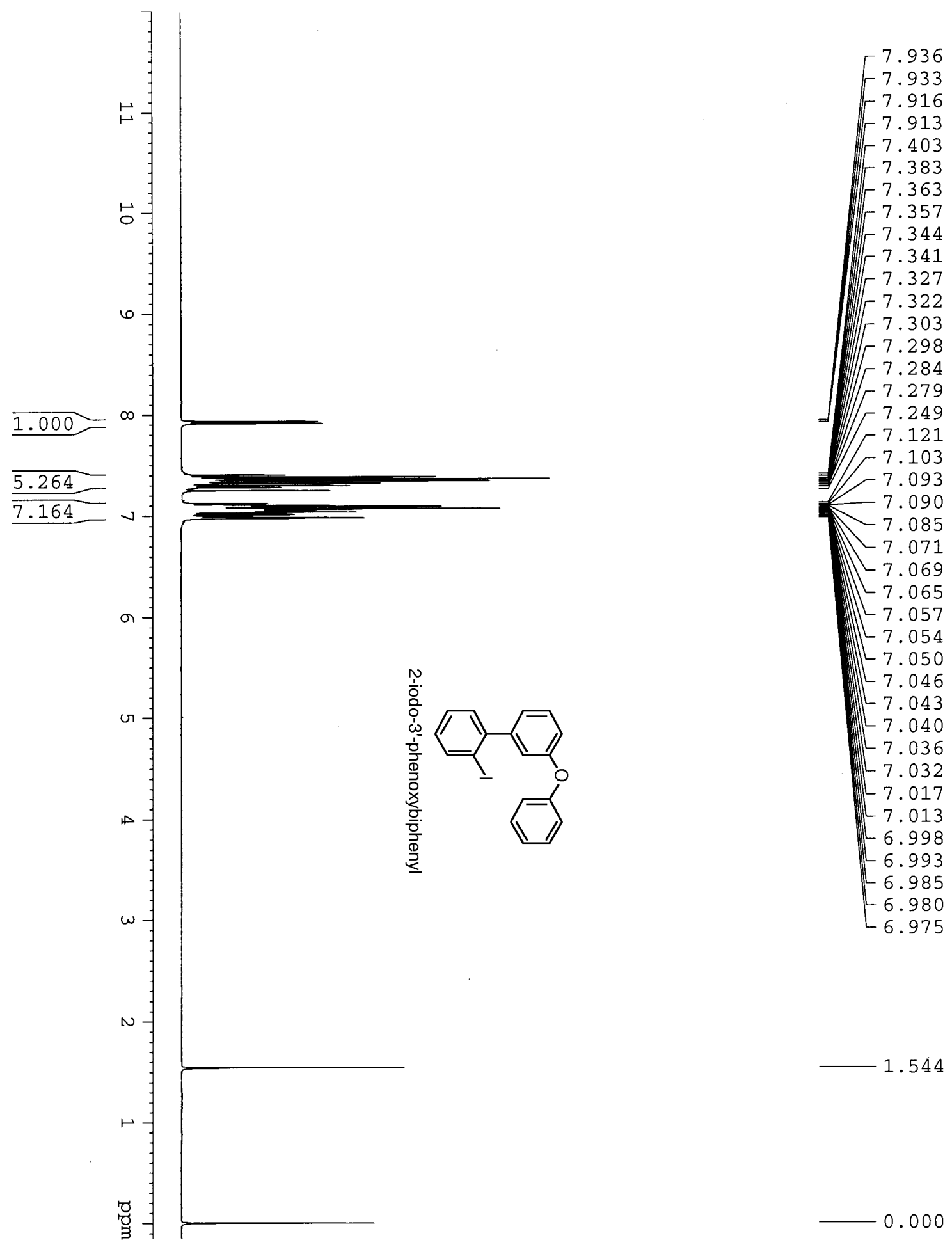


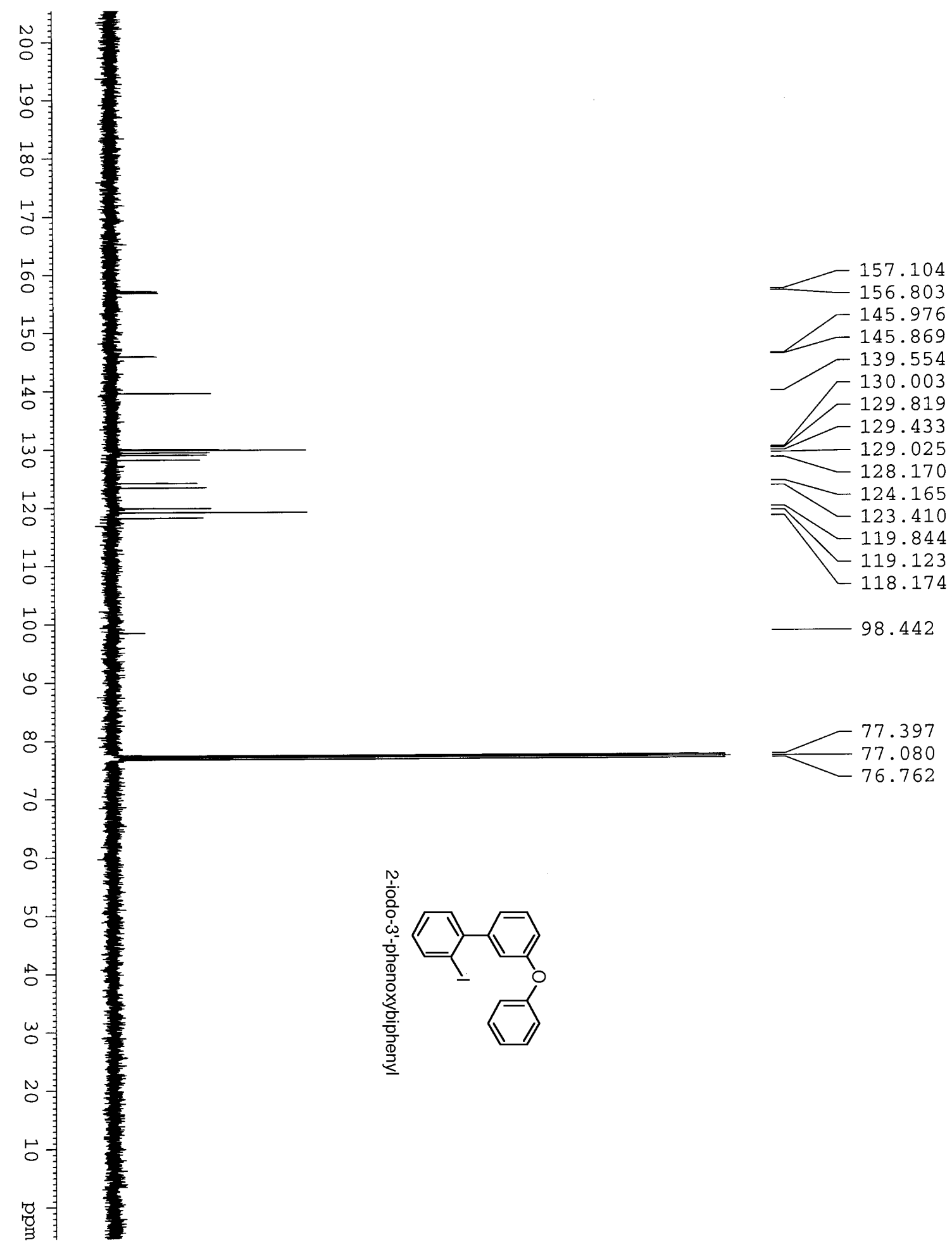



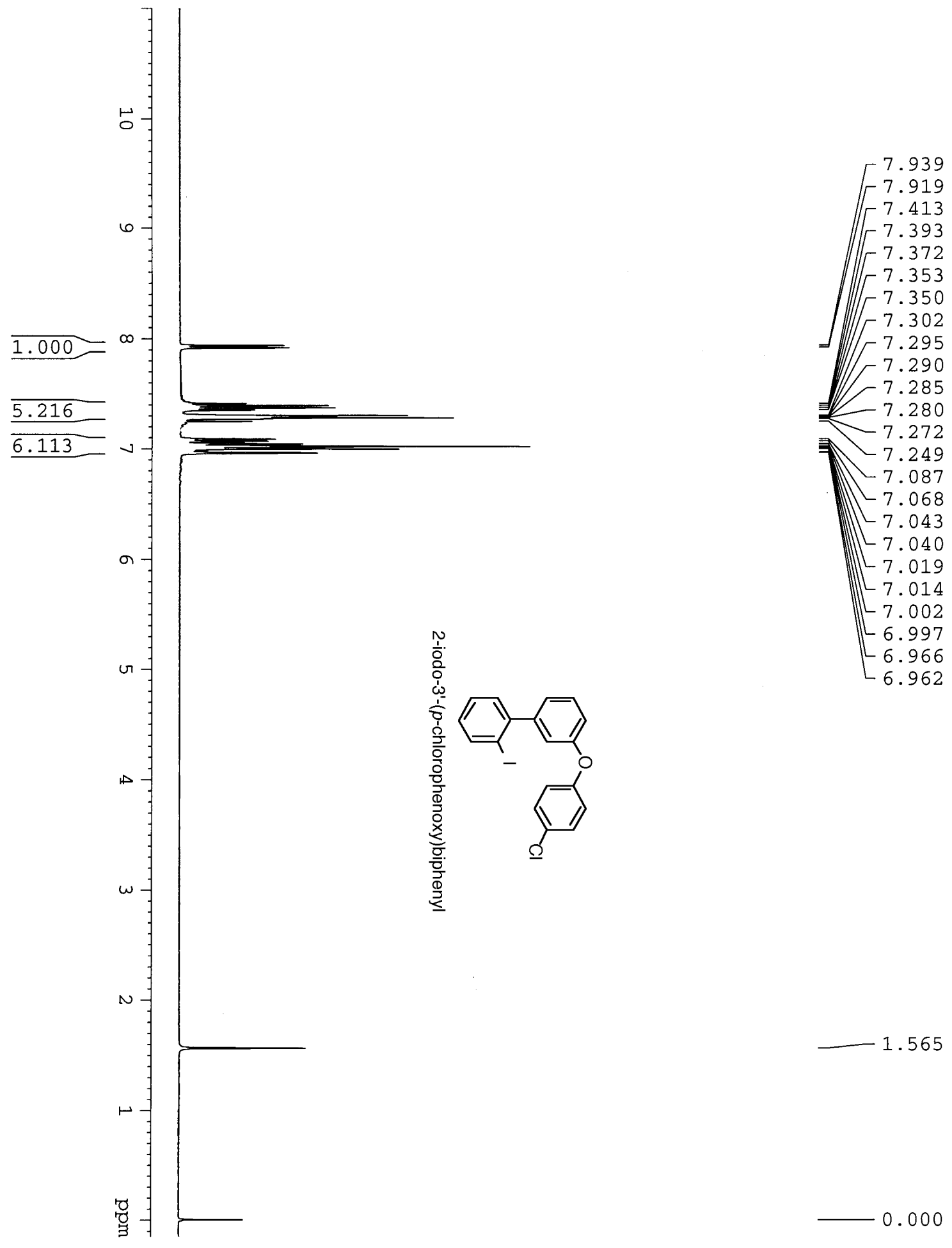


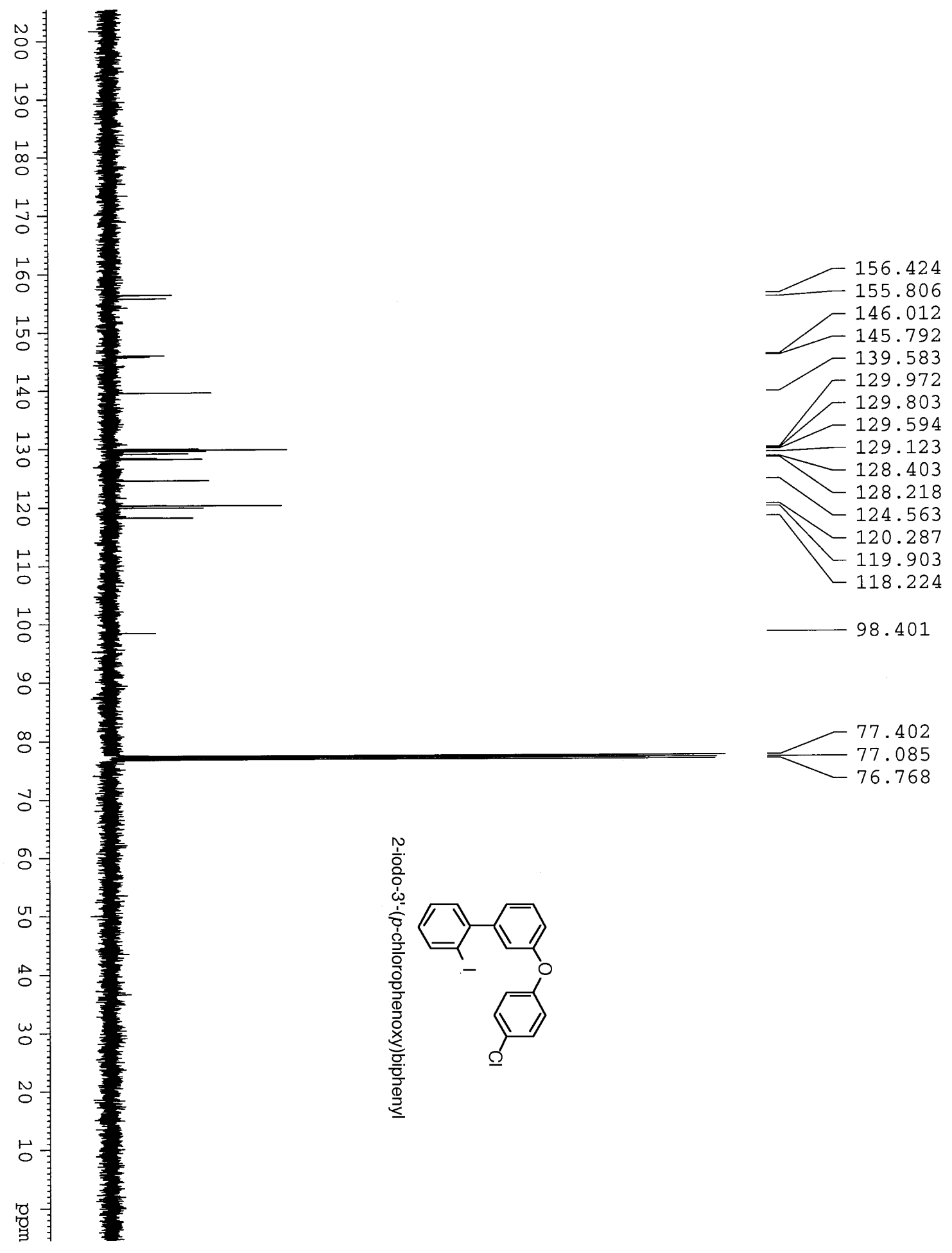



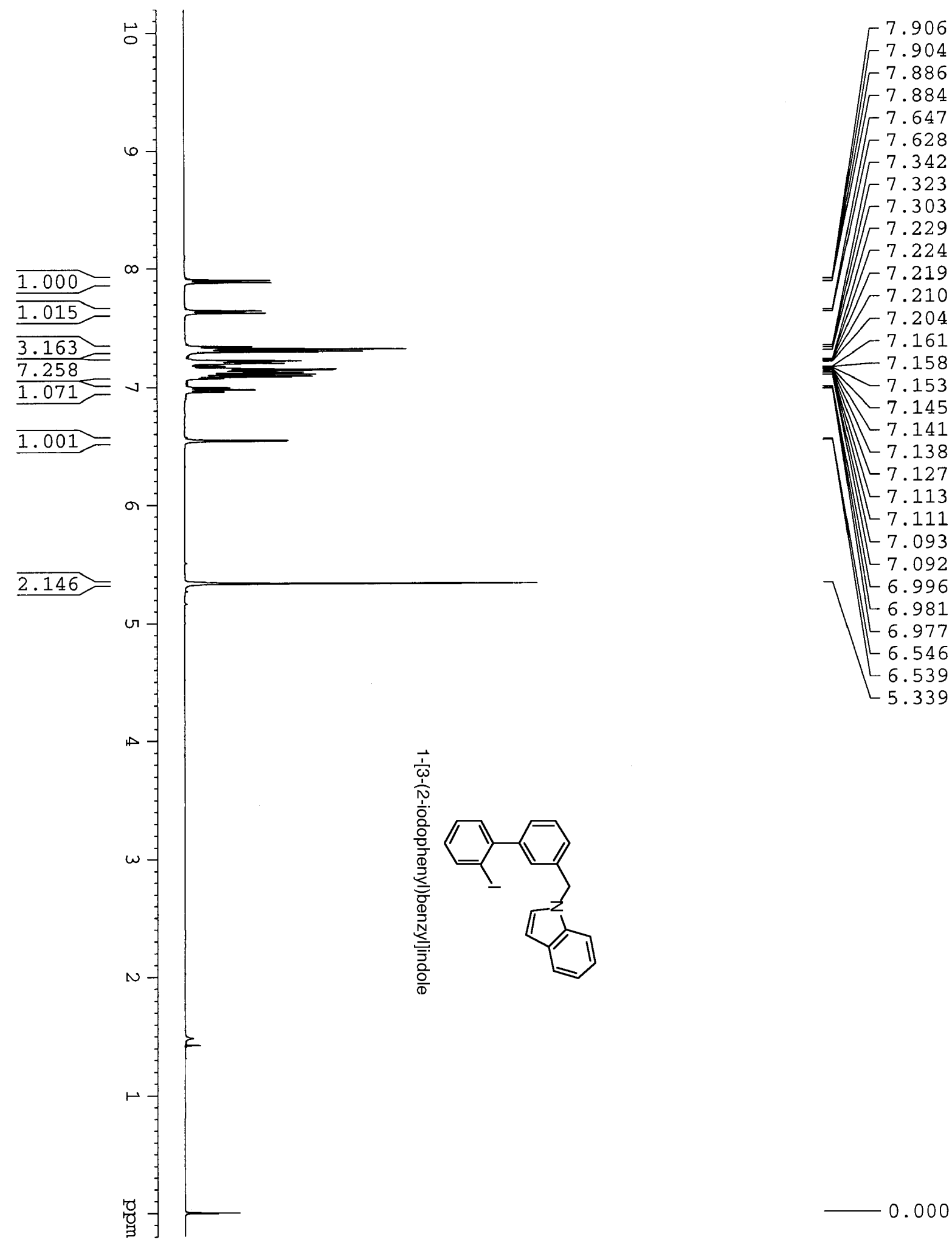

0.000 

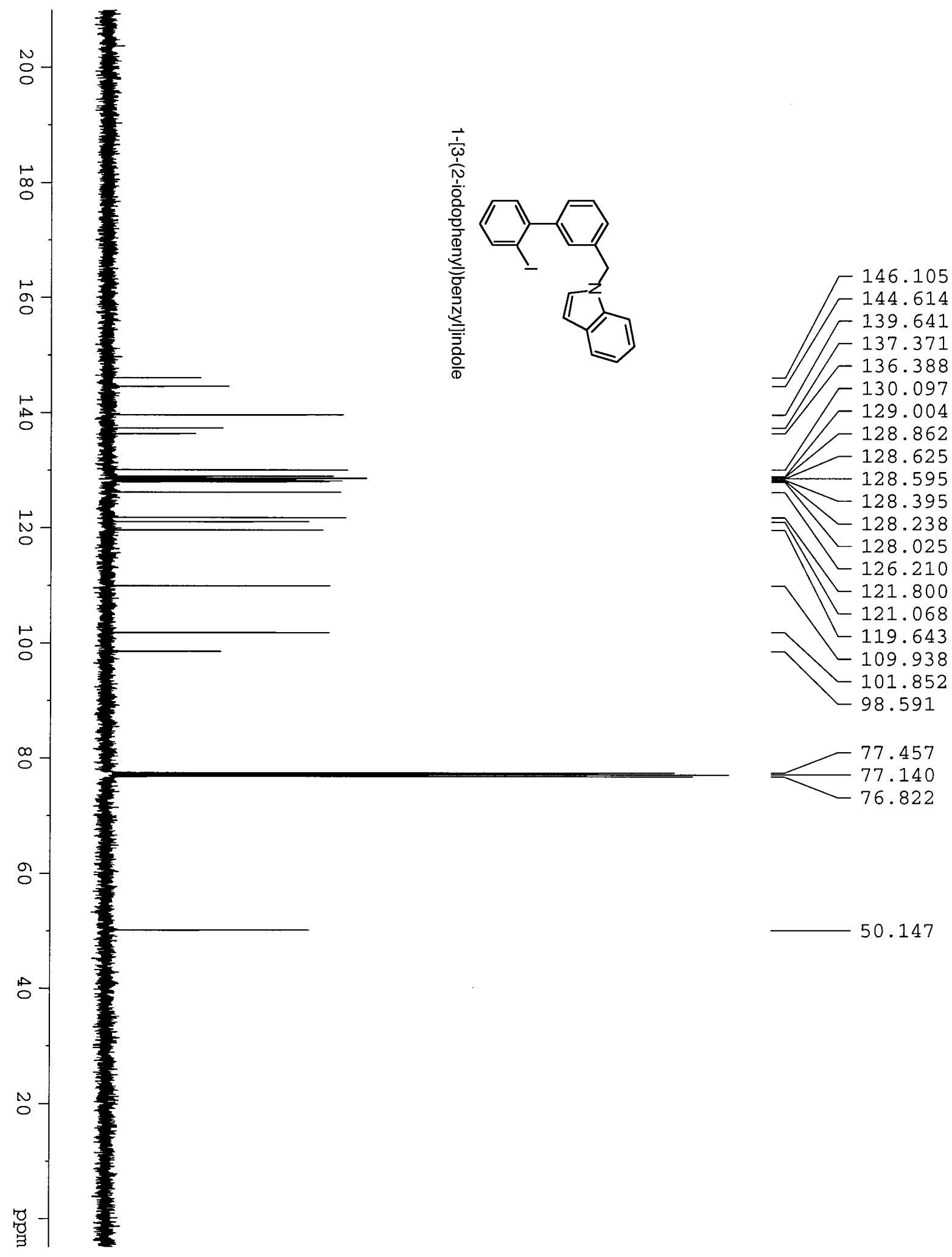

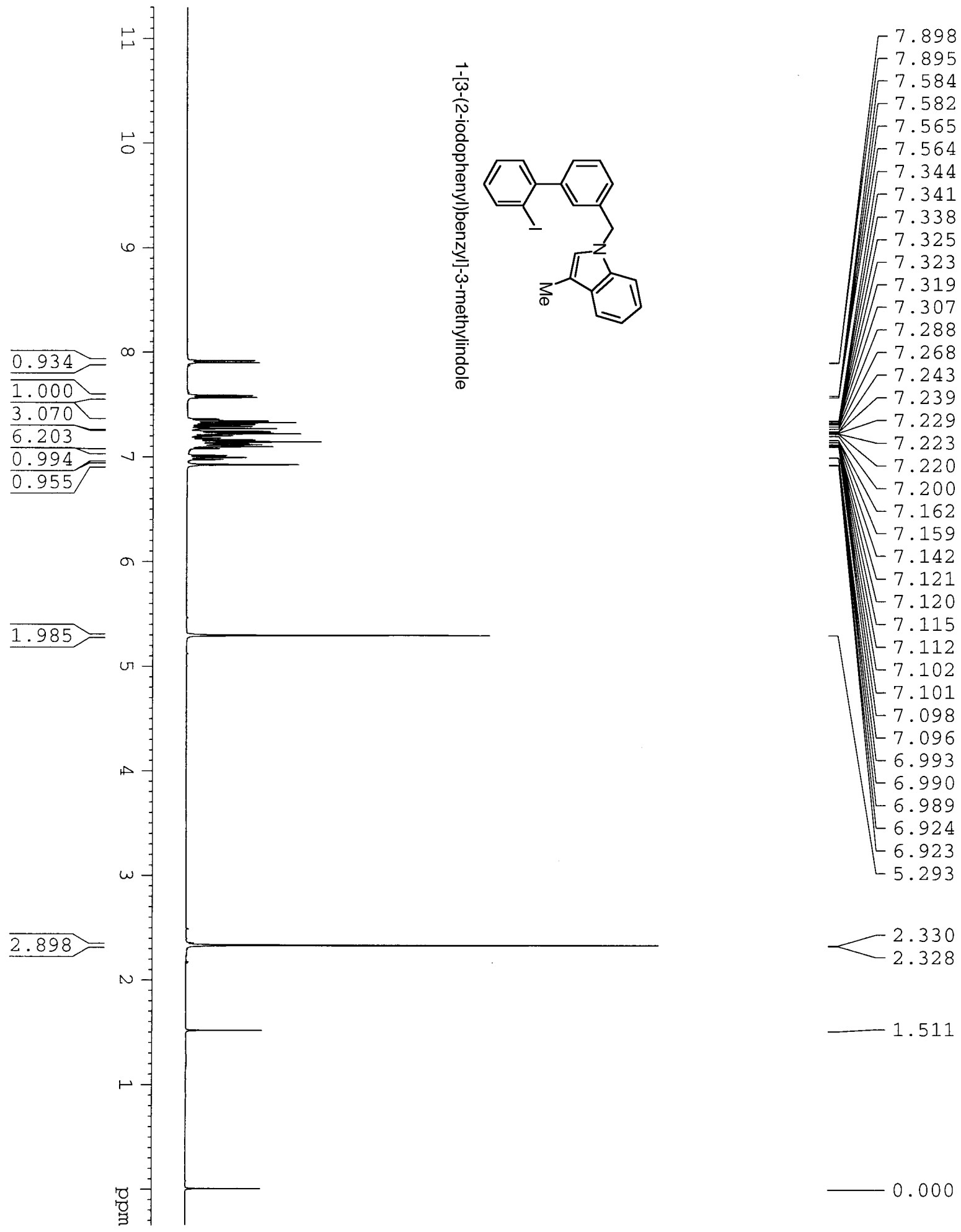

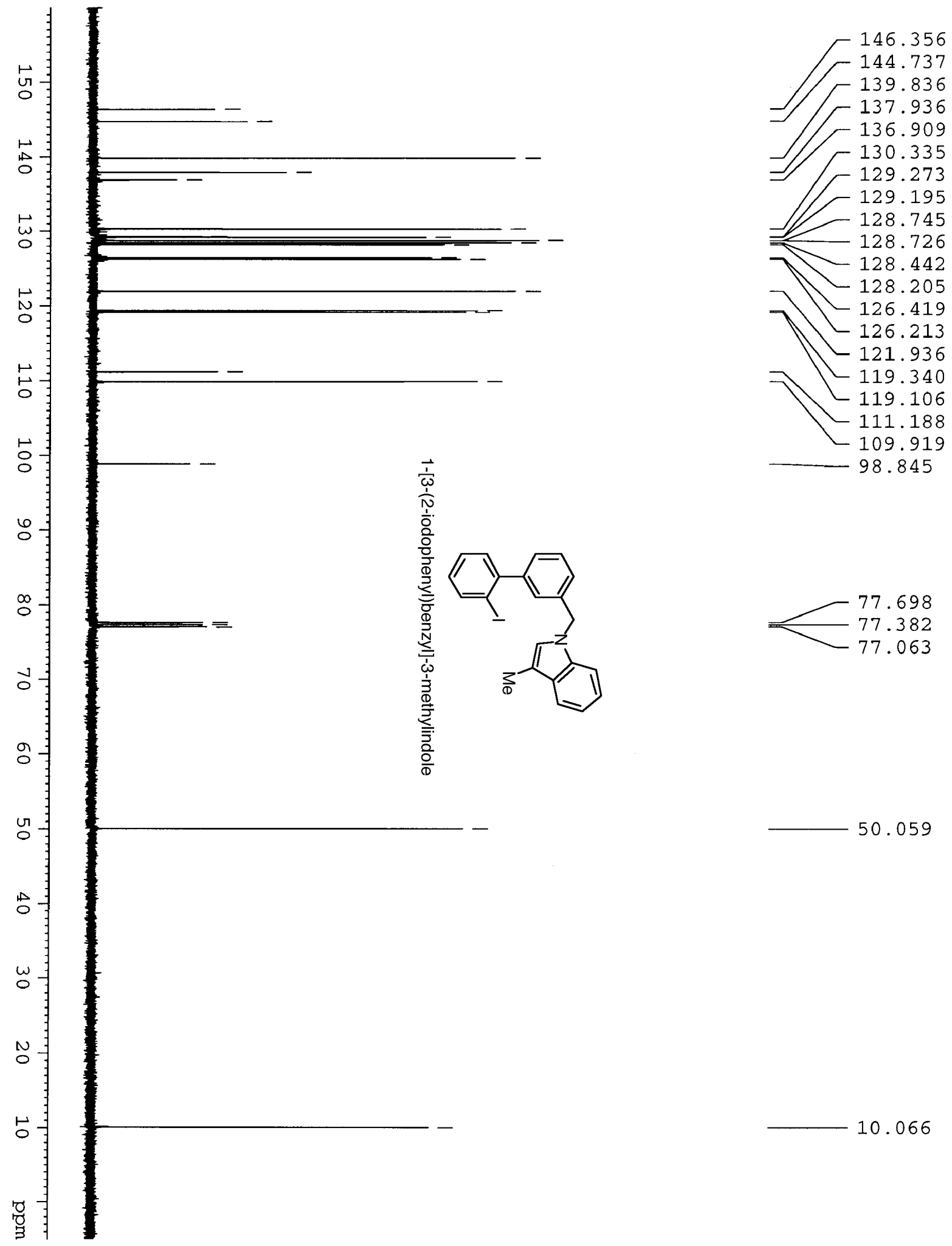

50.059

10.066 

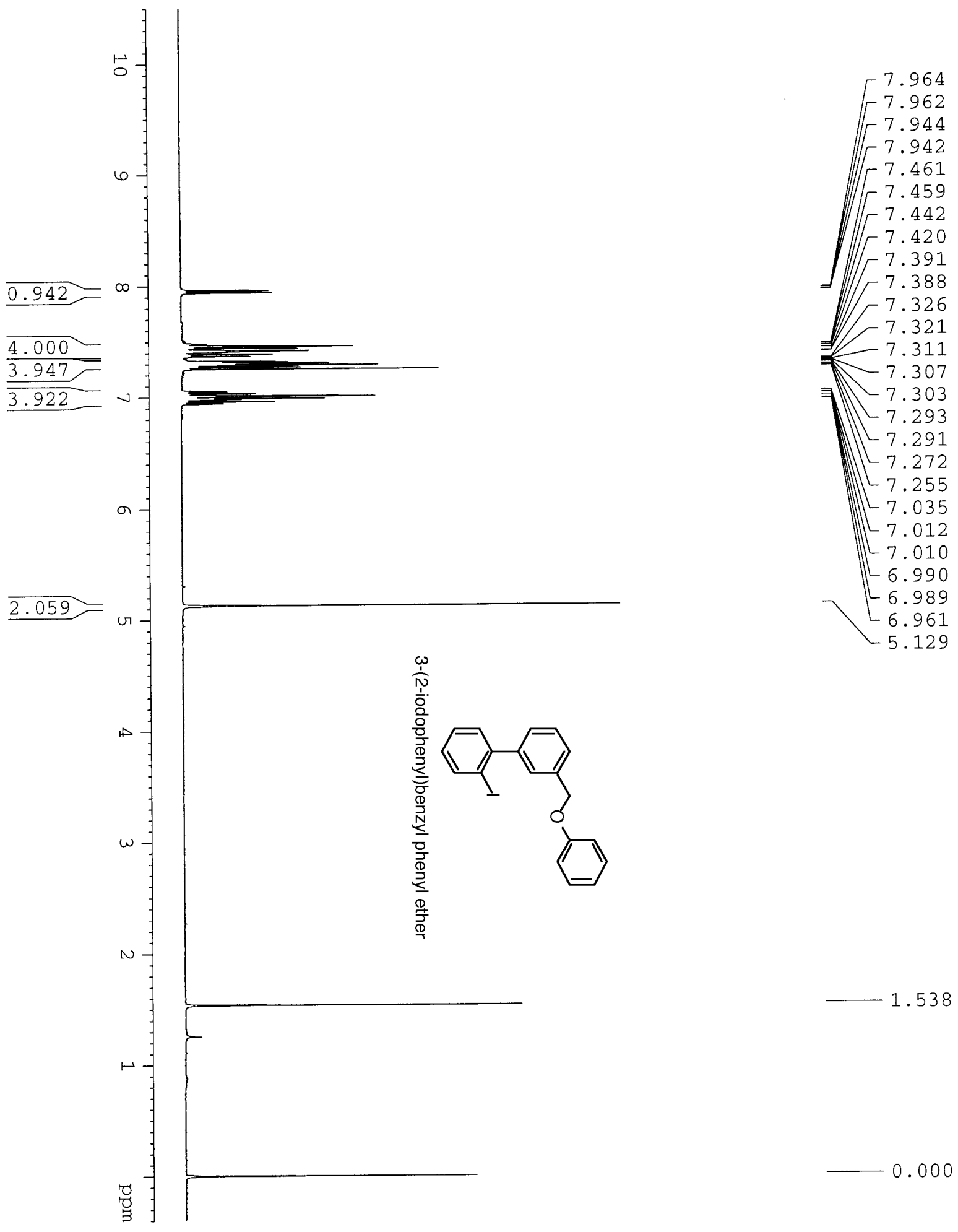

$-0.000$ 

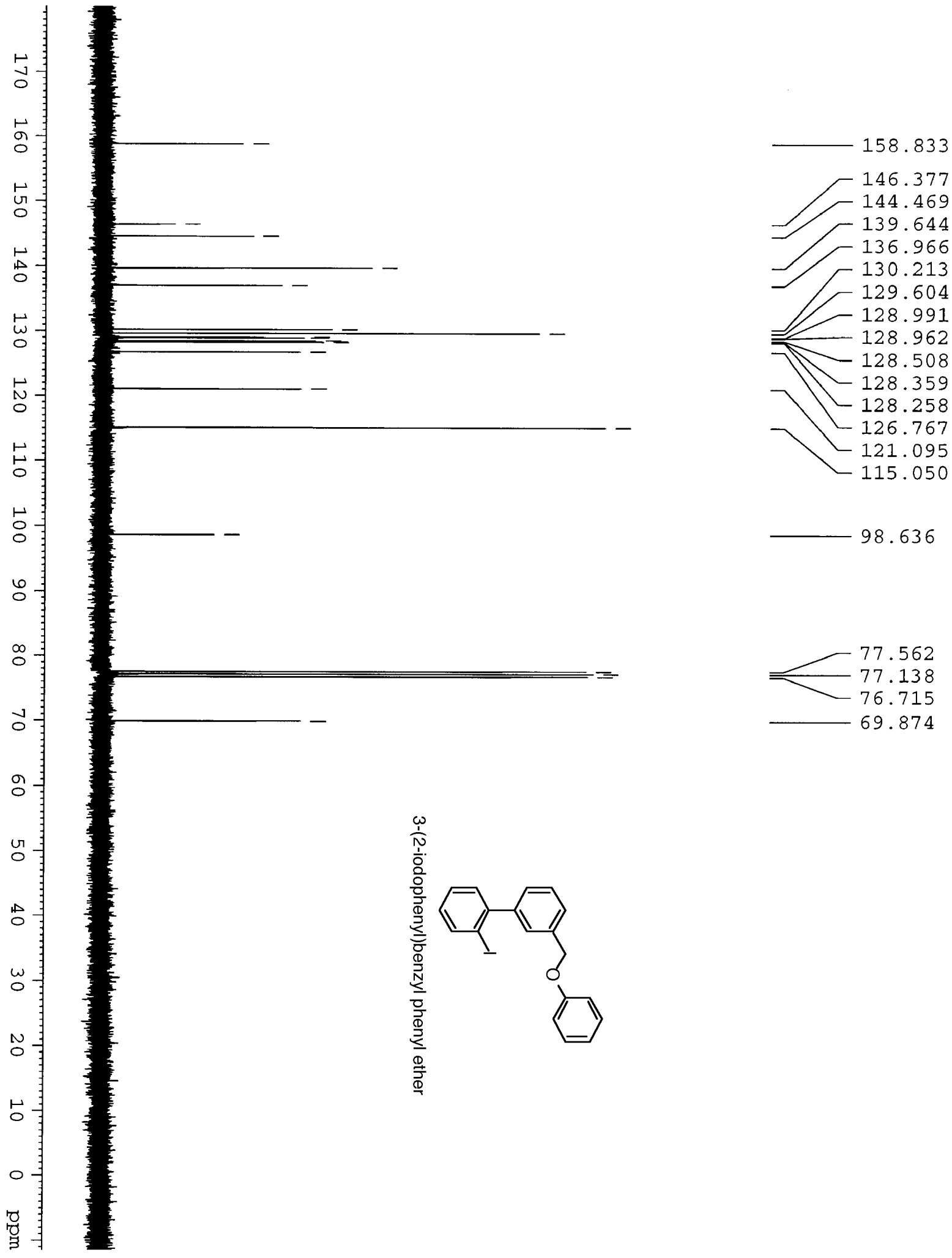

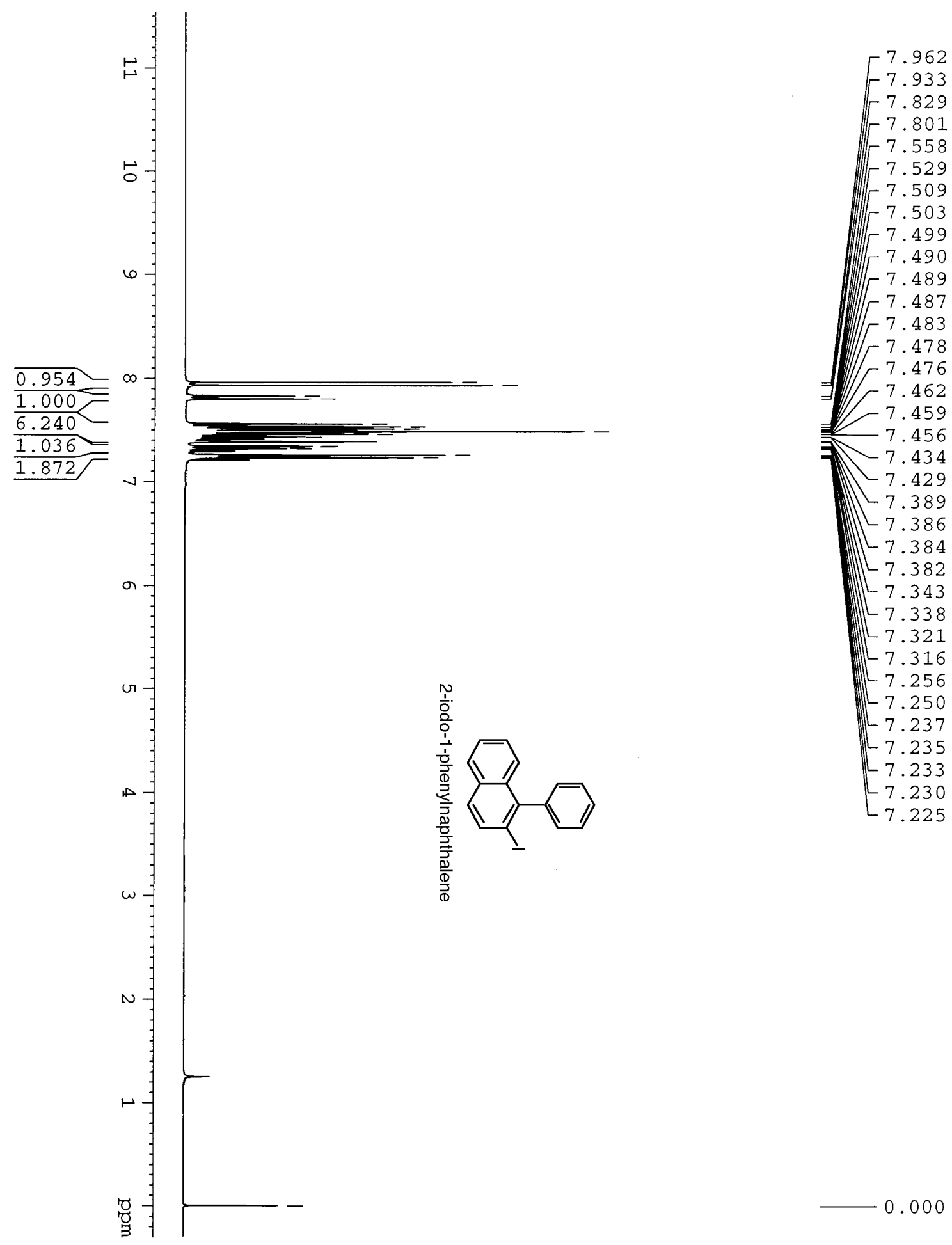

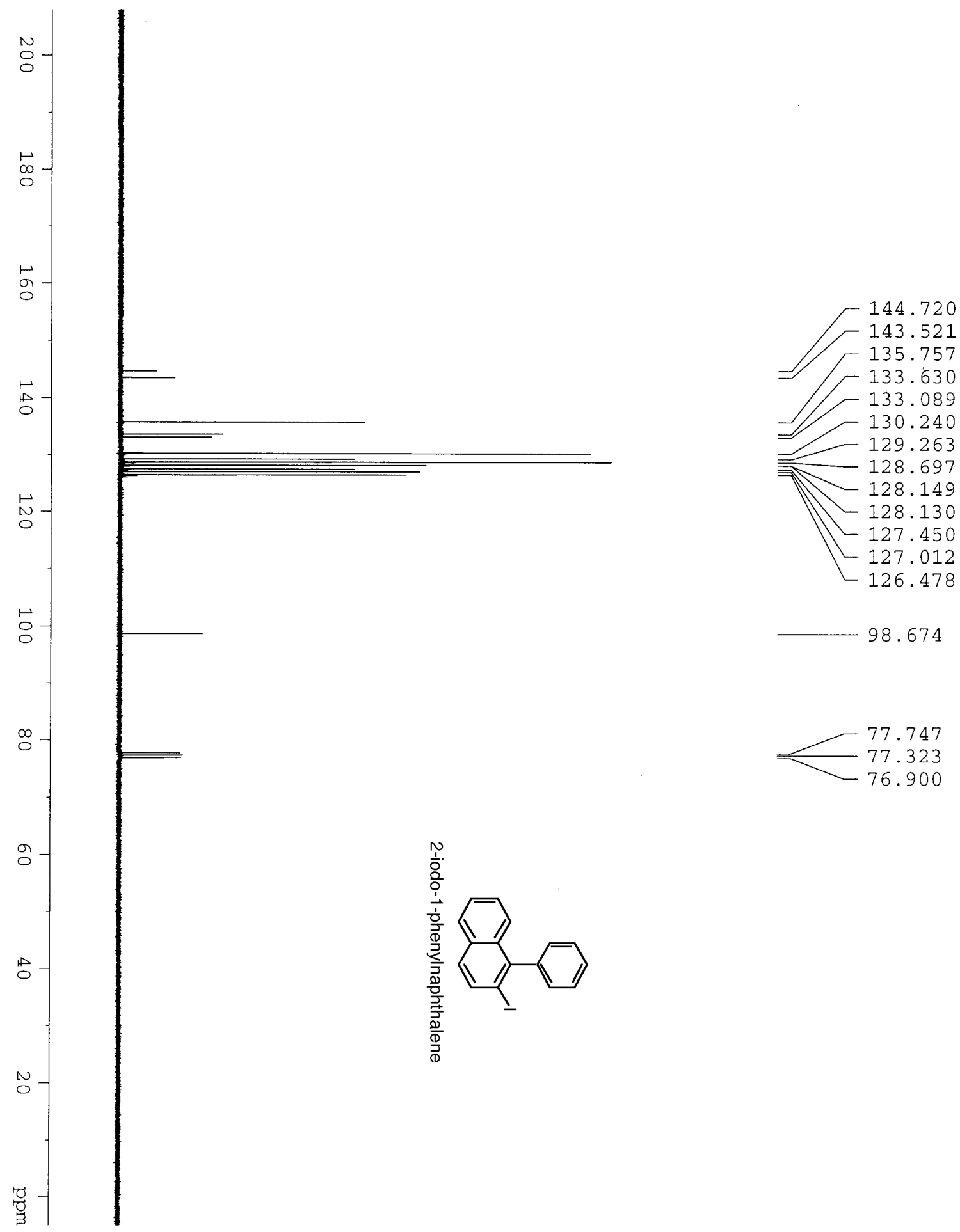


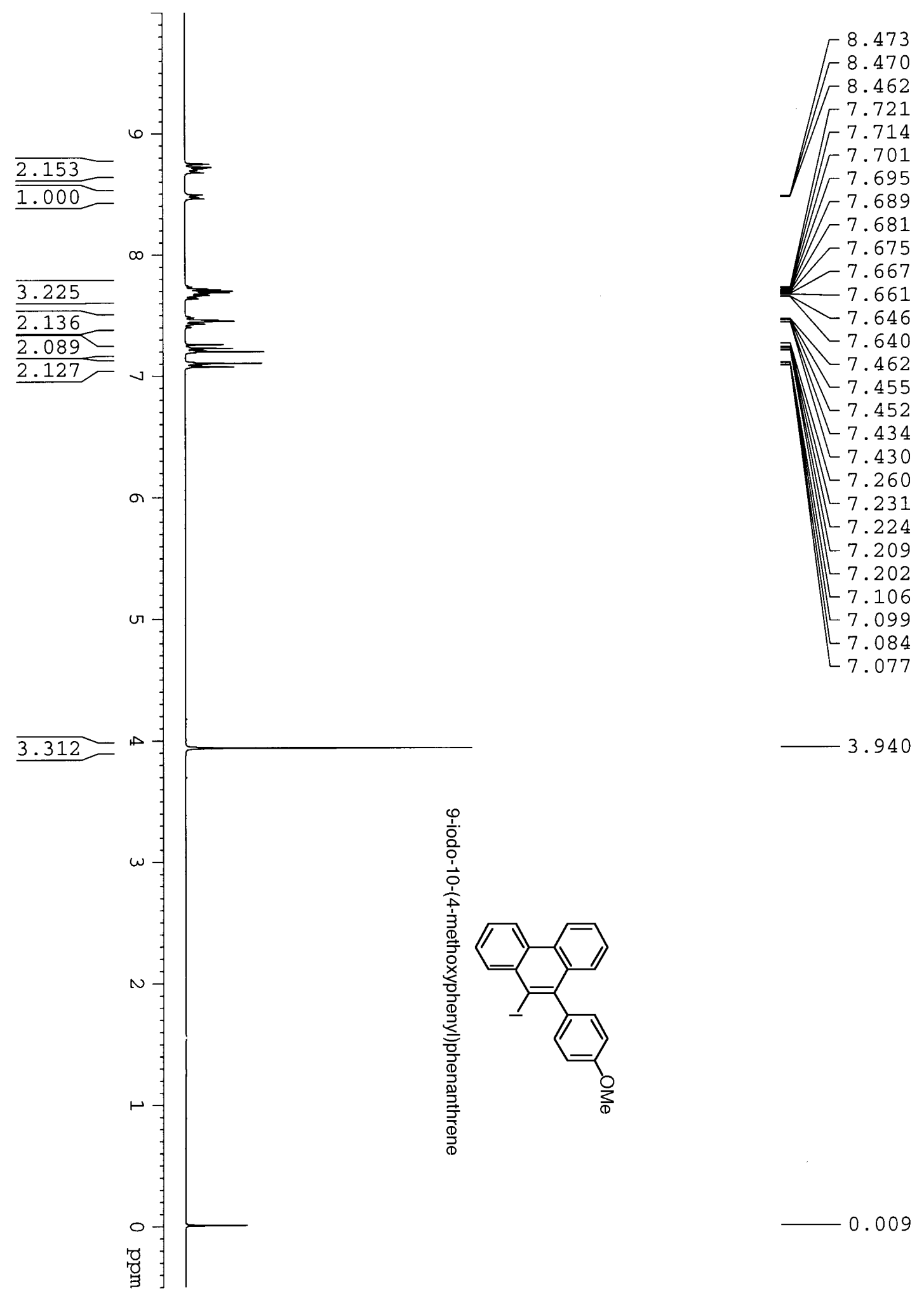



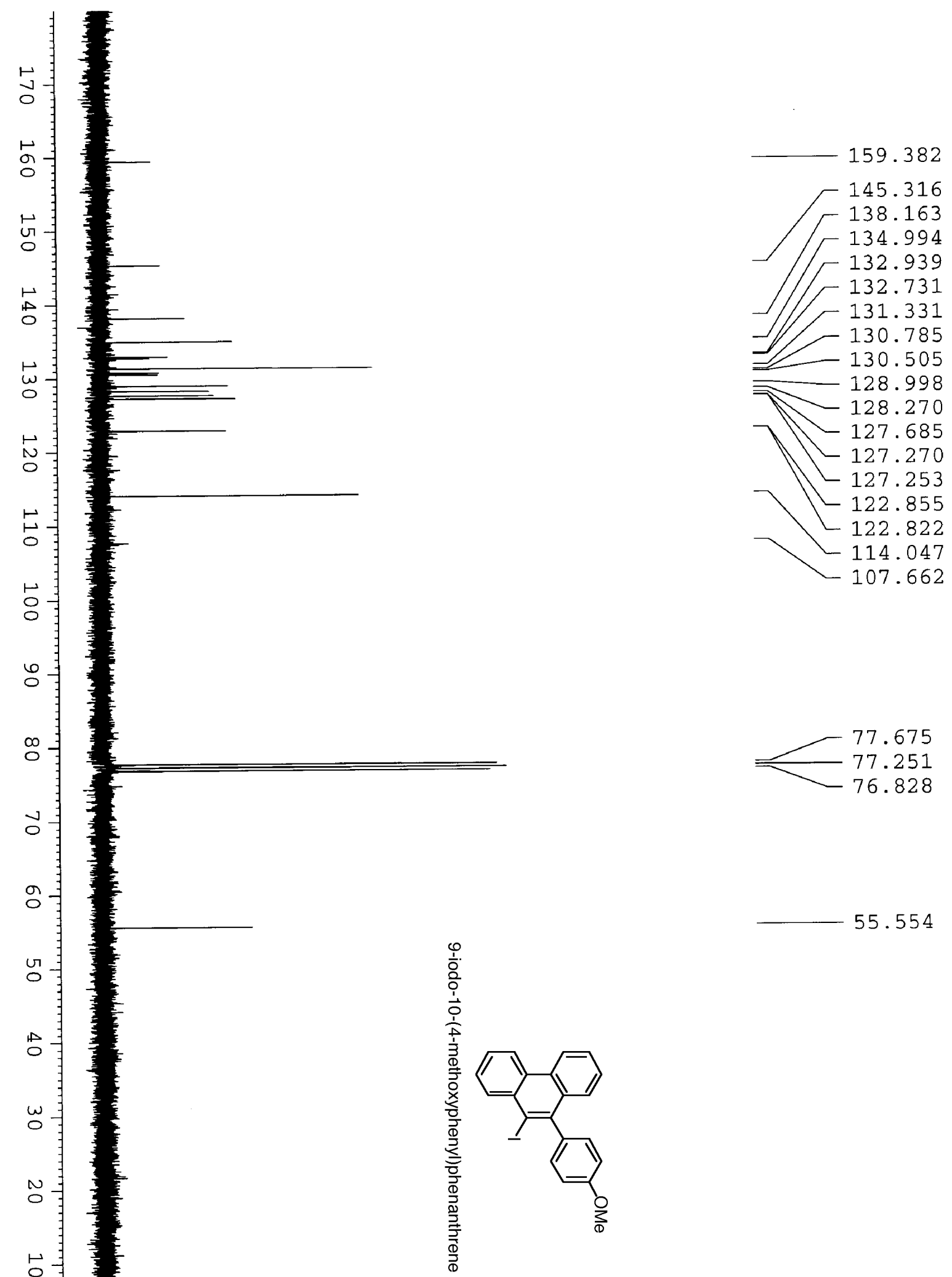

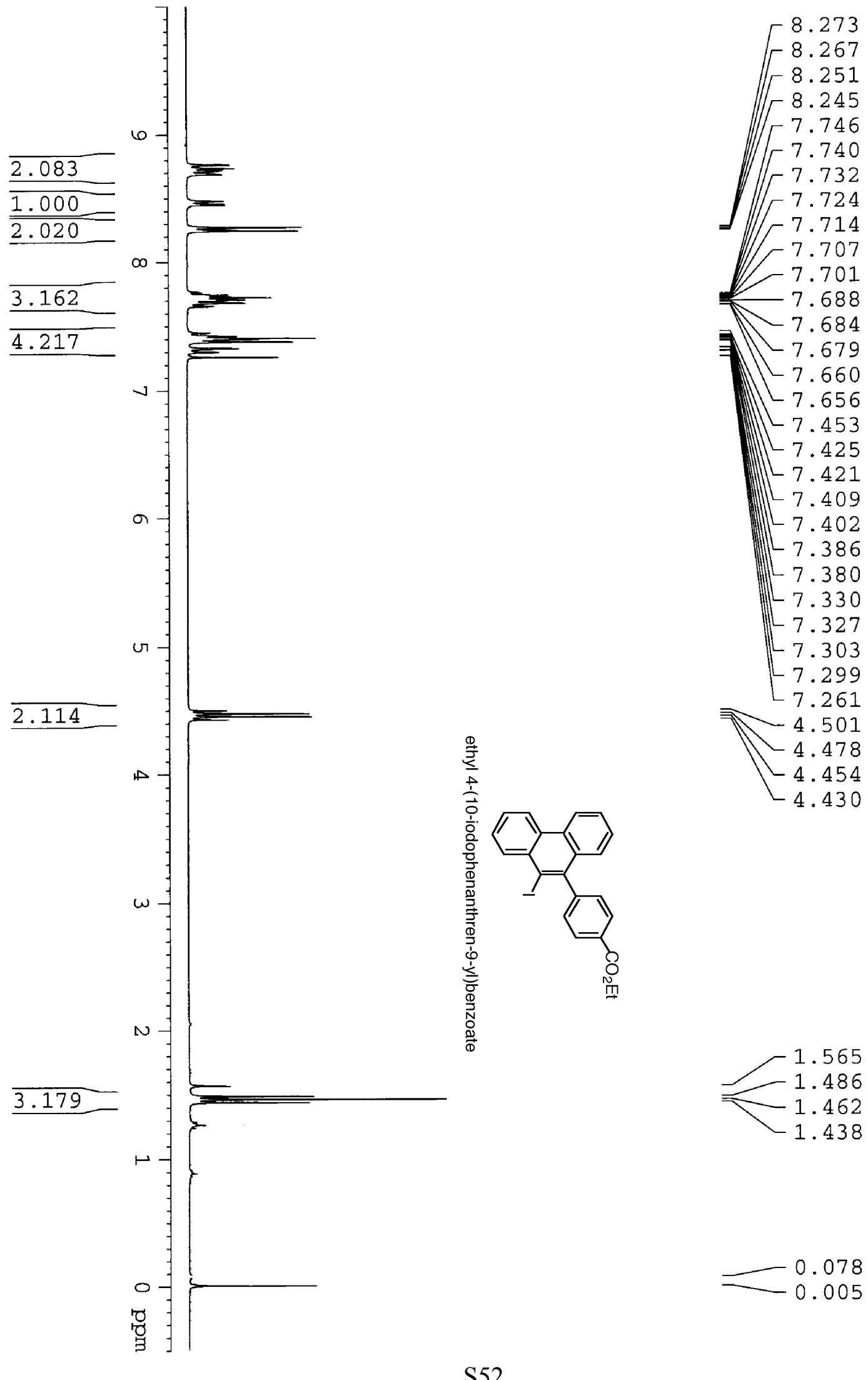

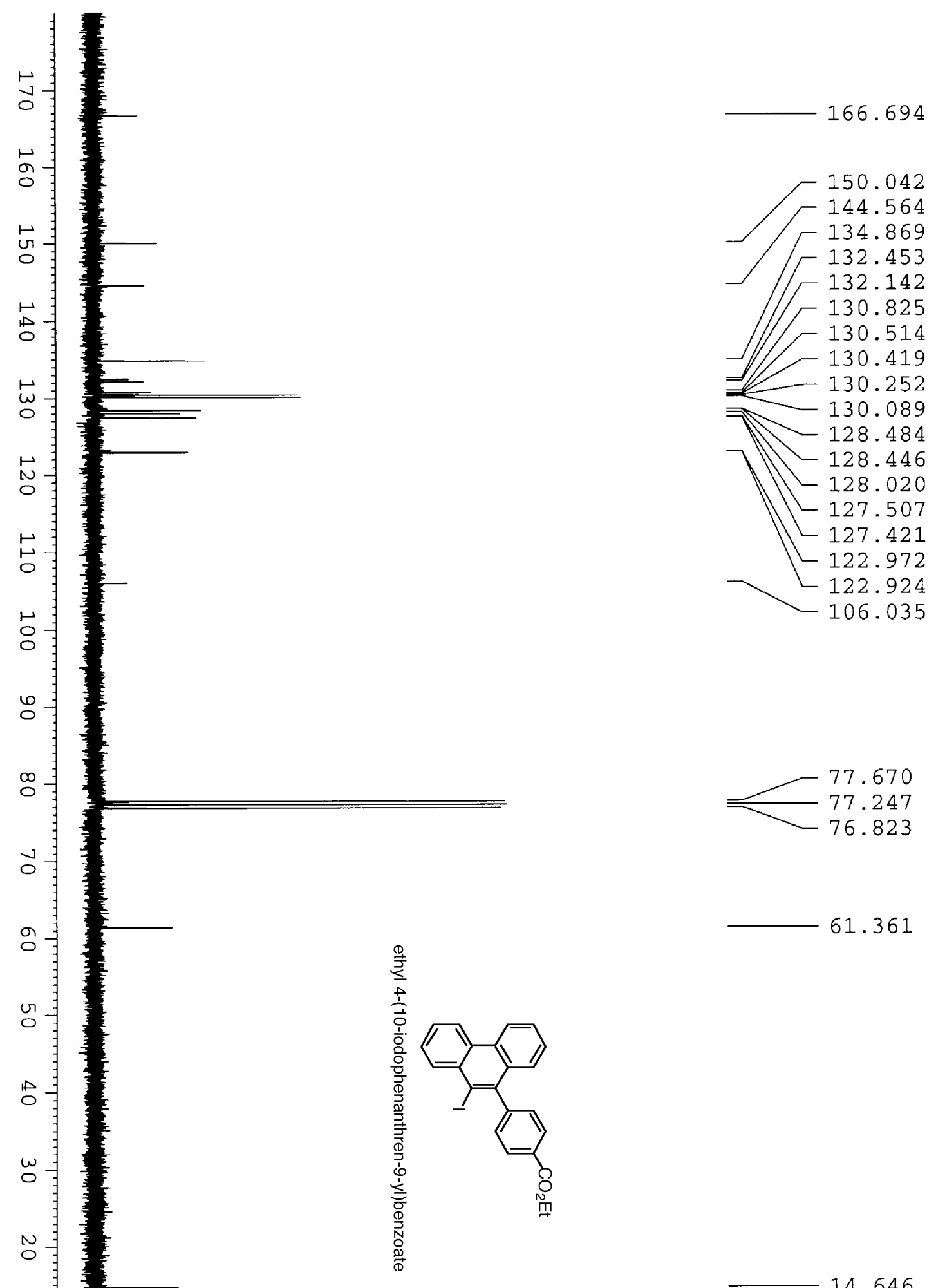

$-61.361$ 


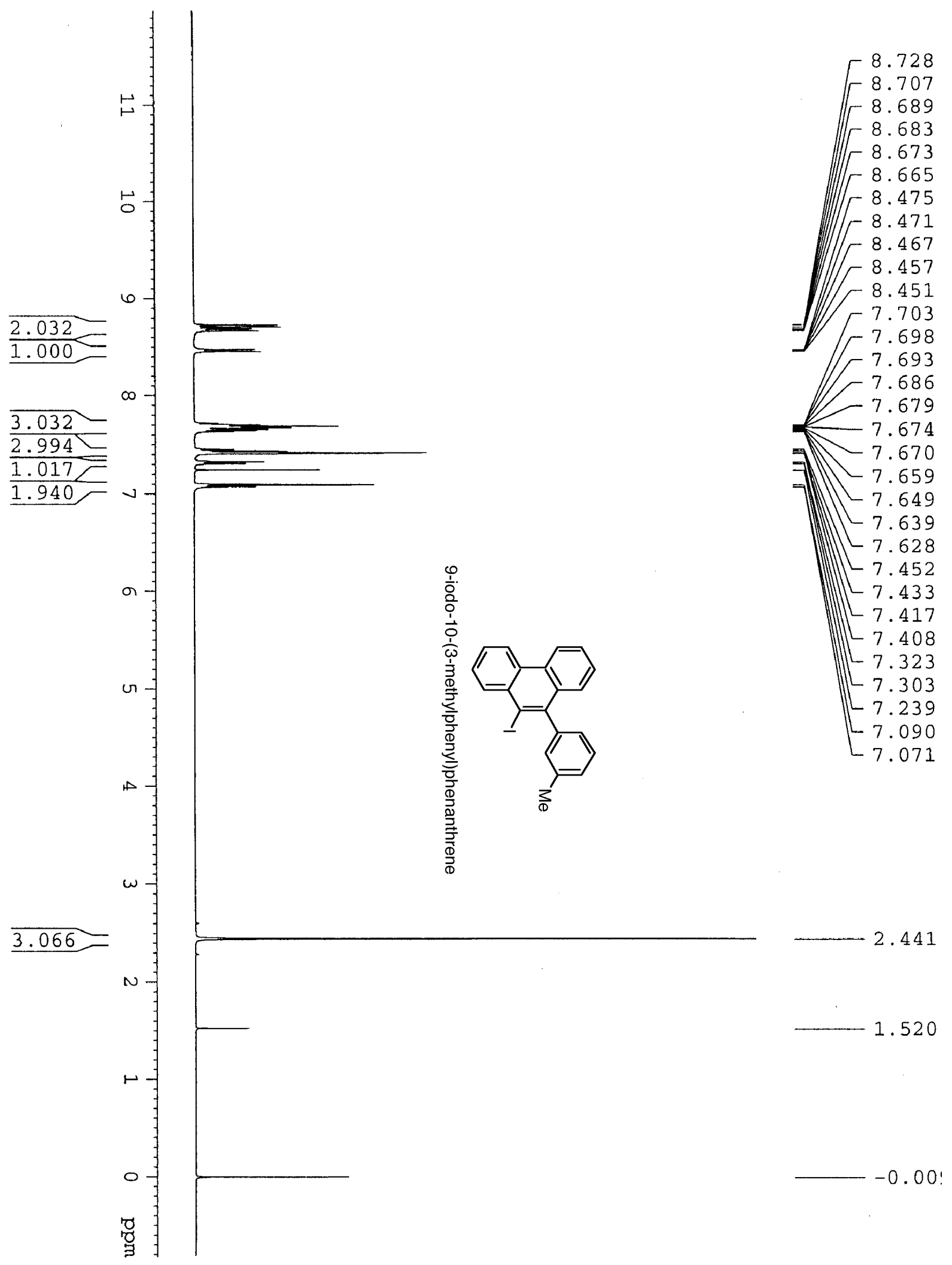




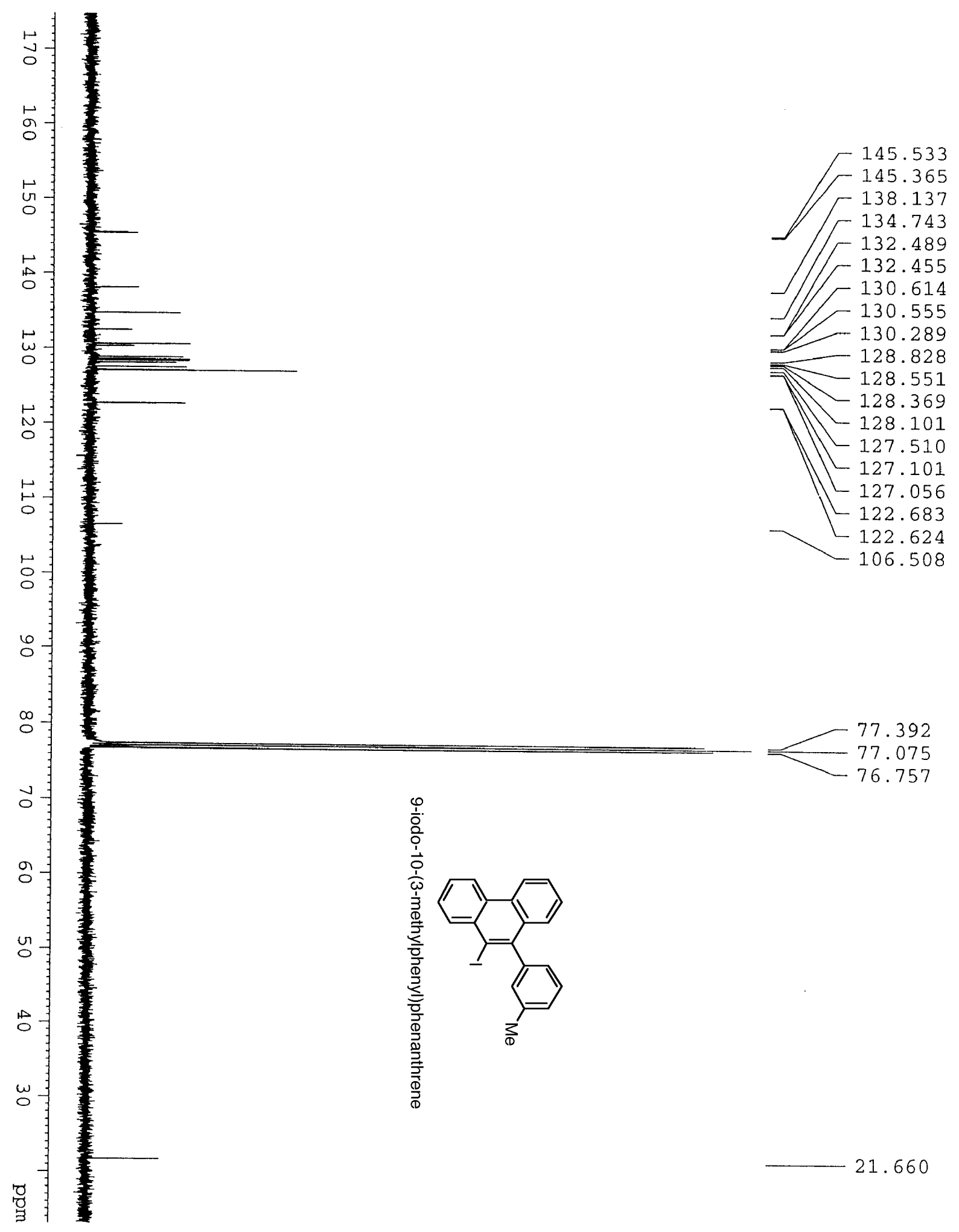



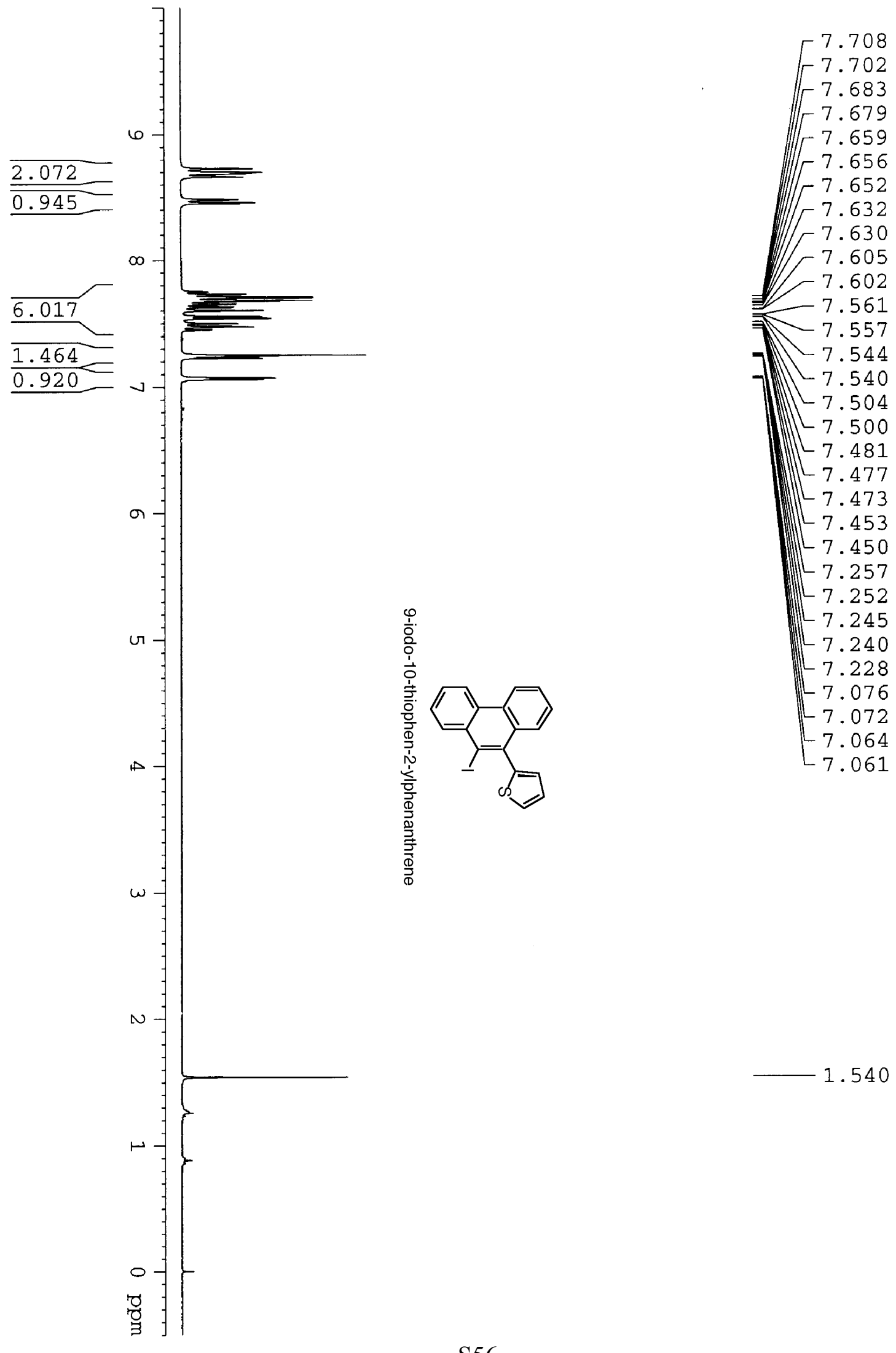


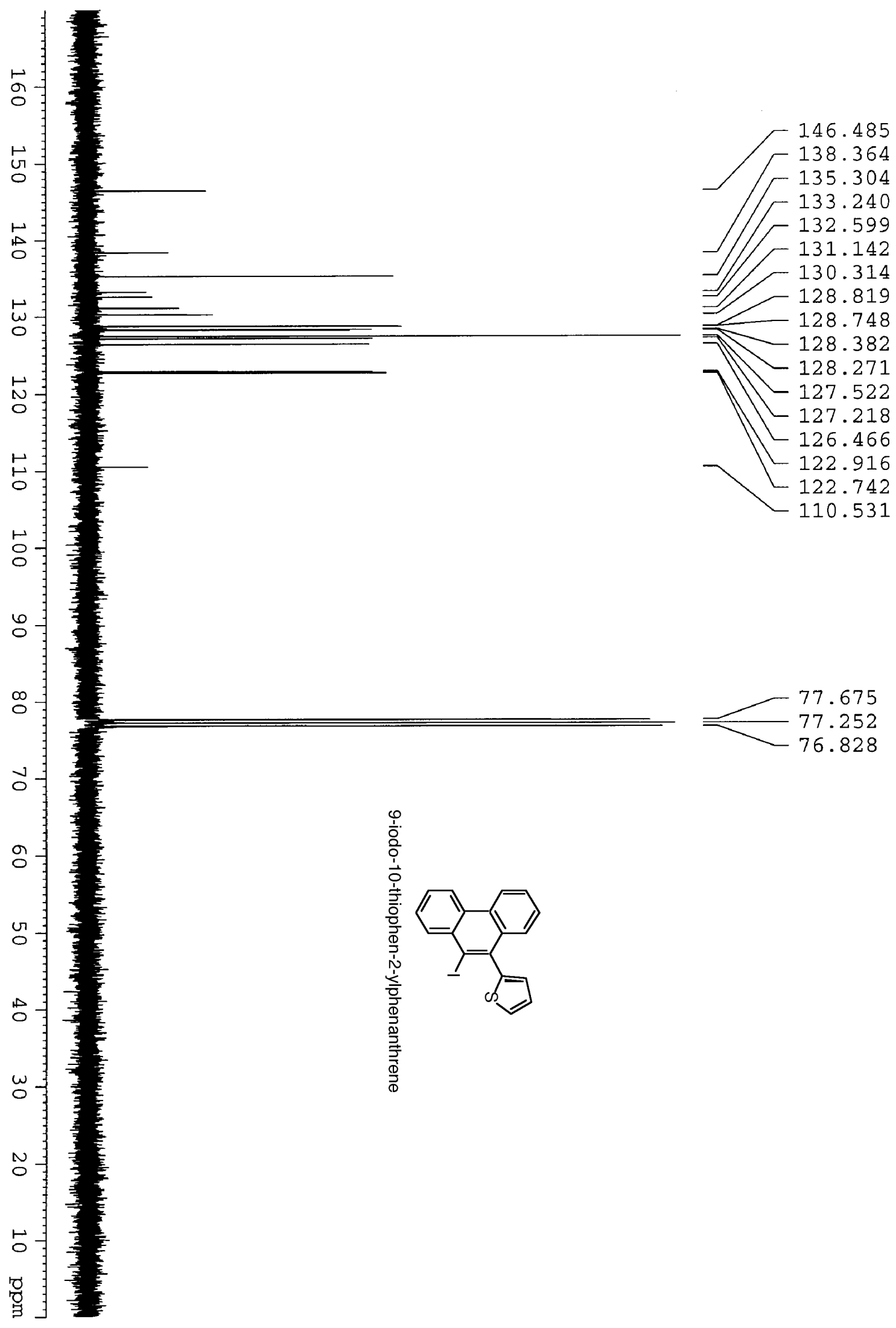




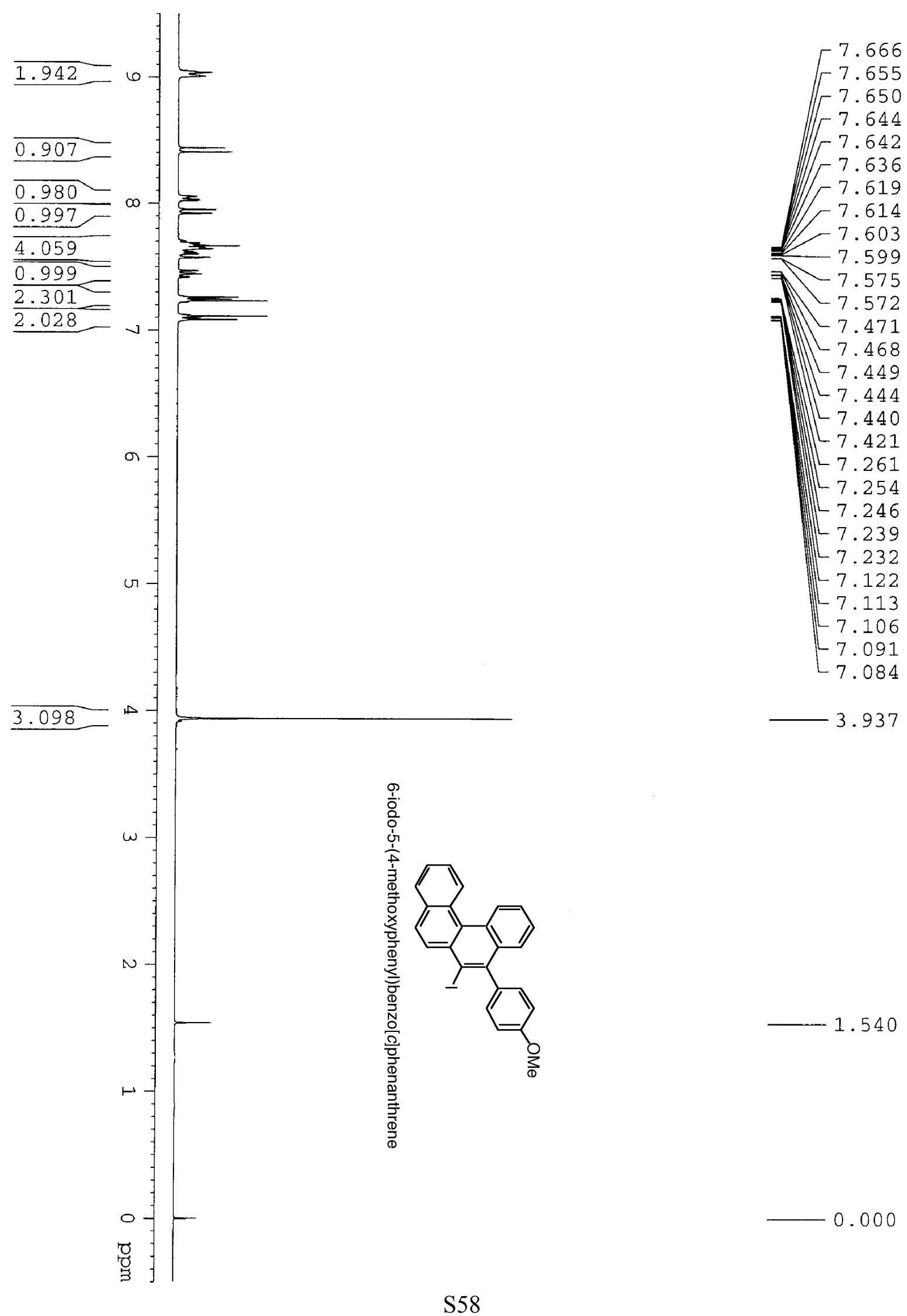




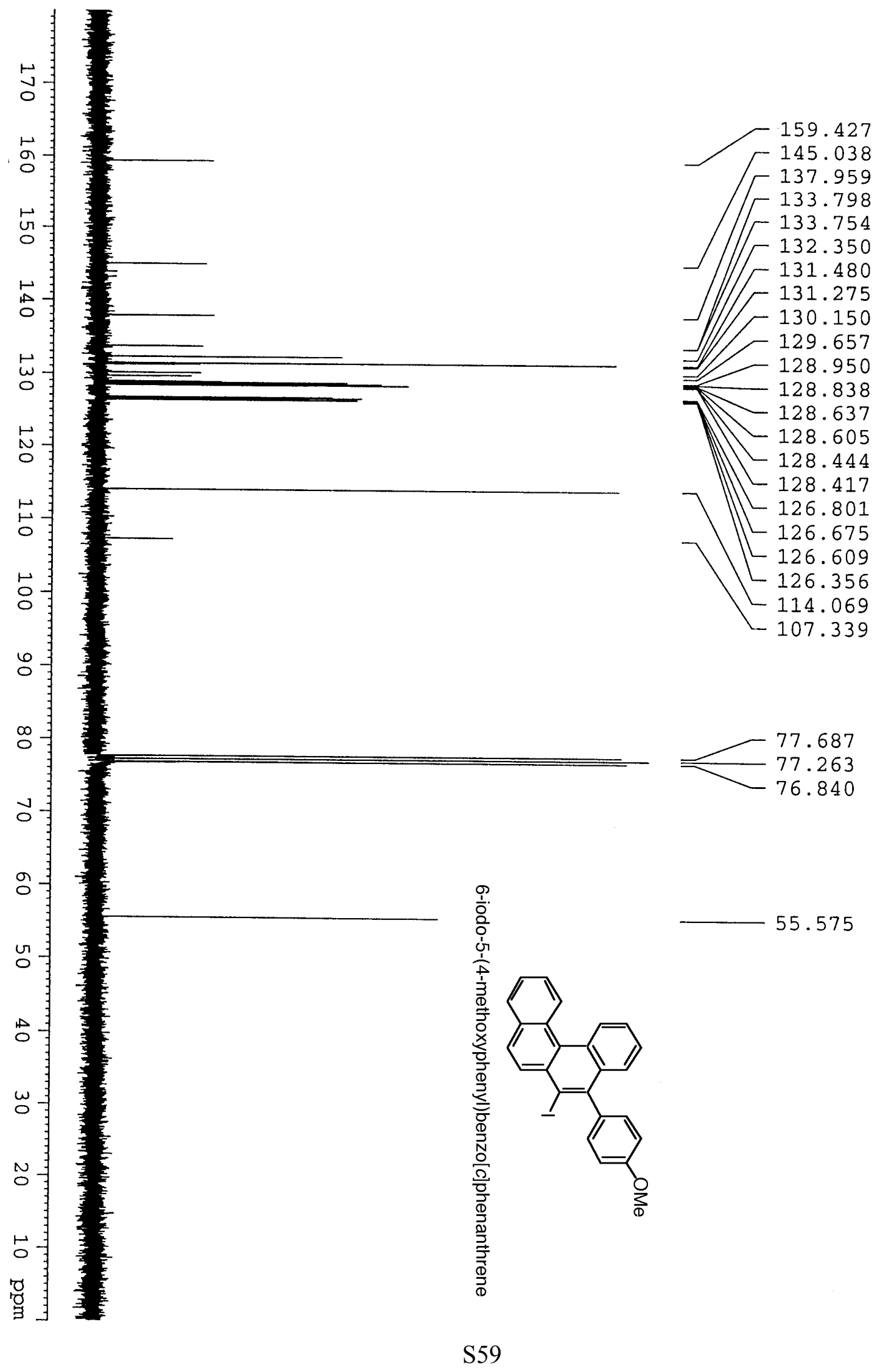



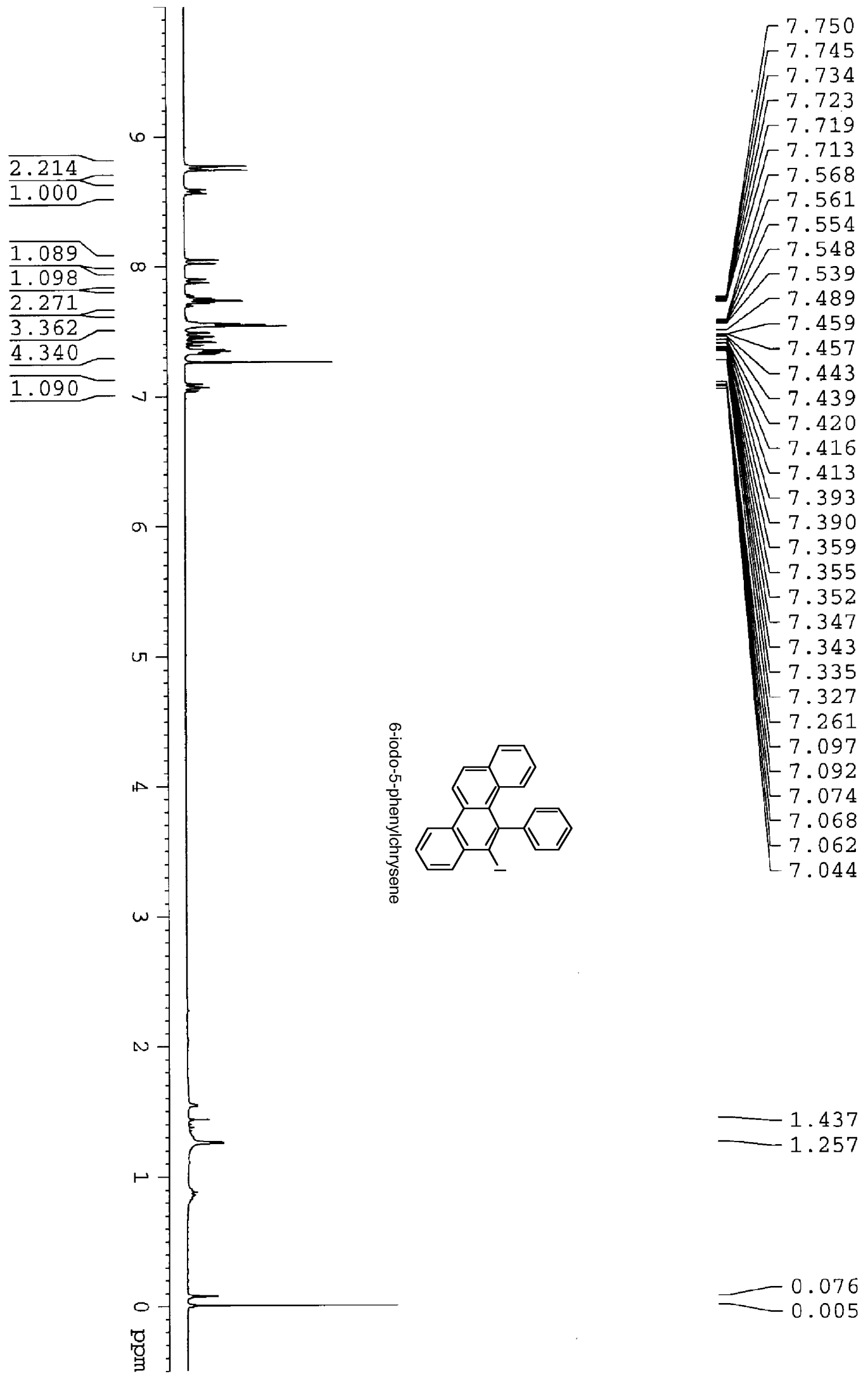

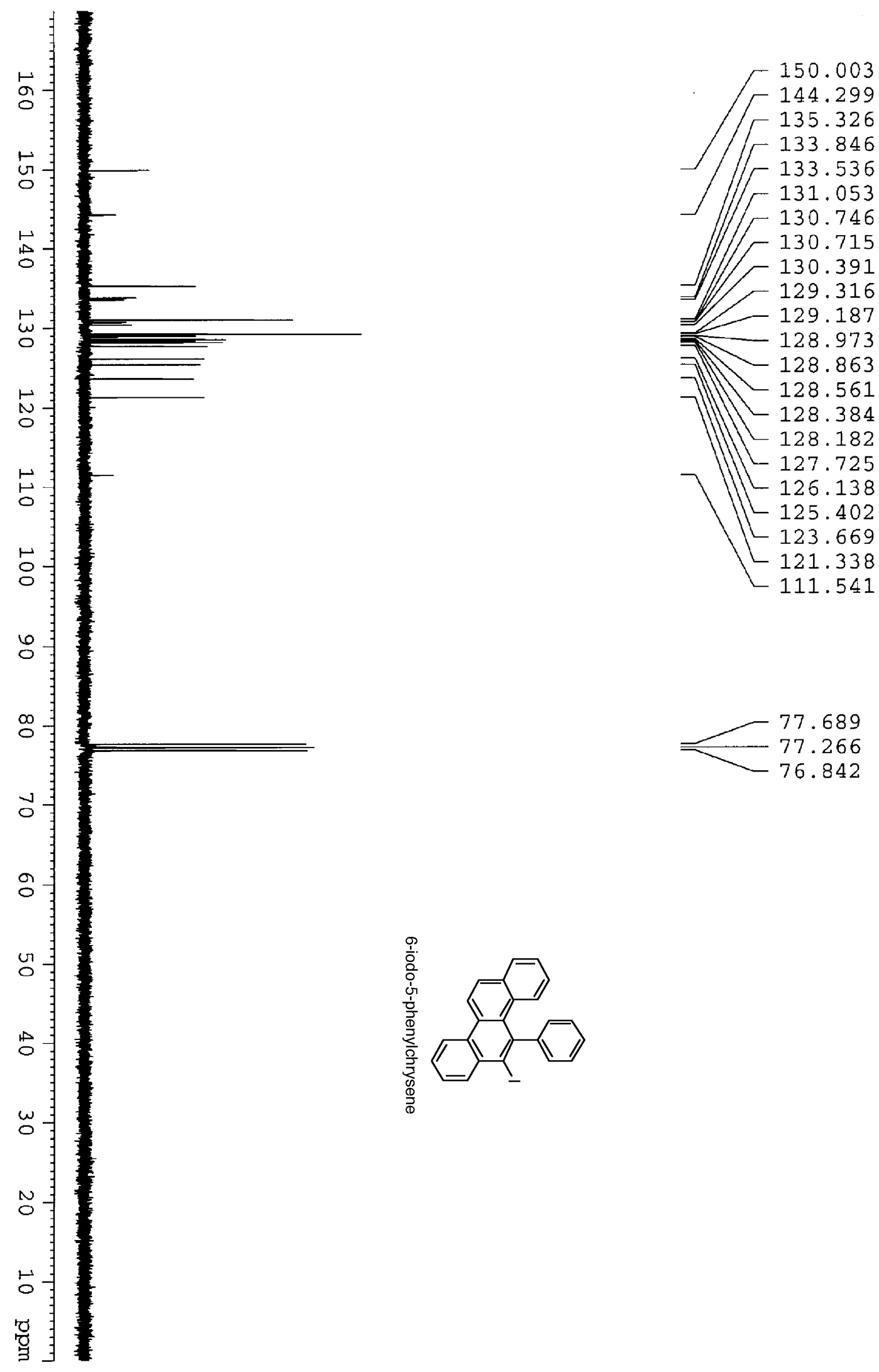

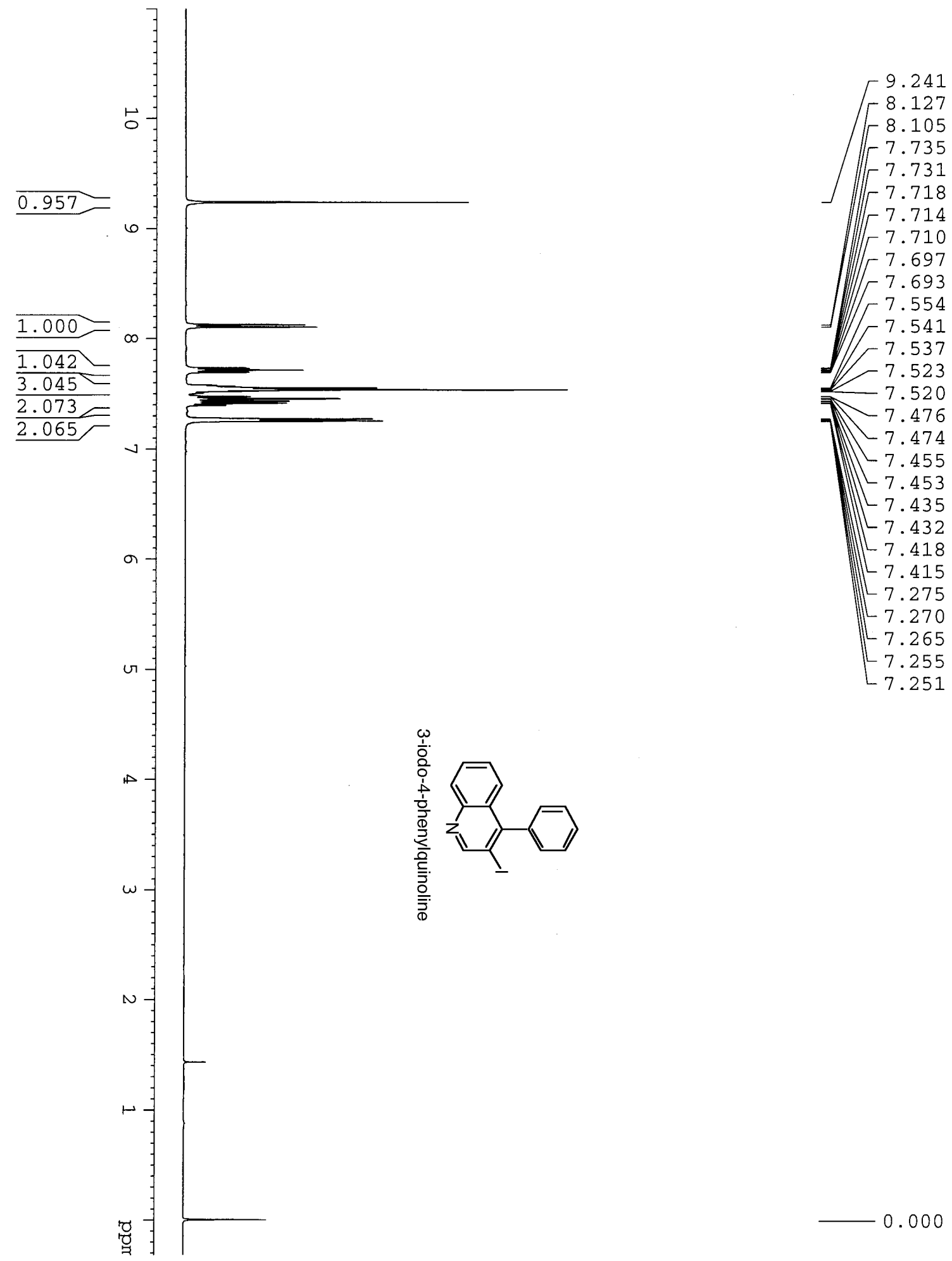

0.000 


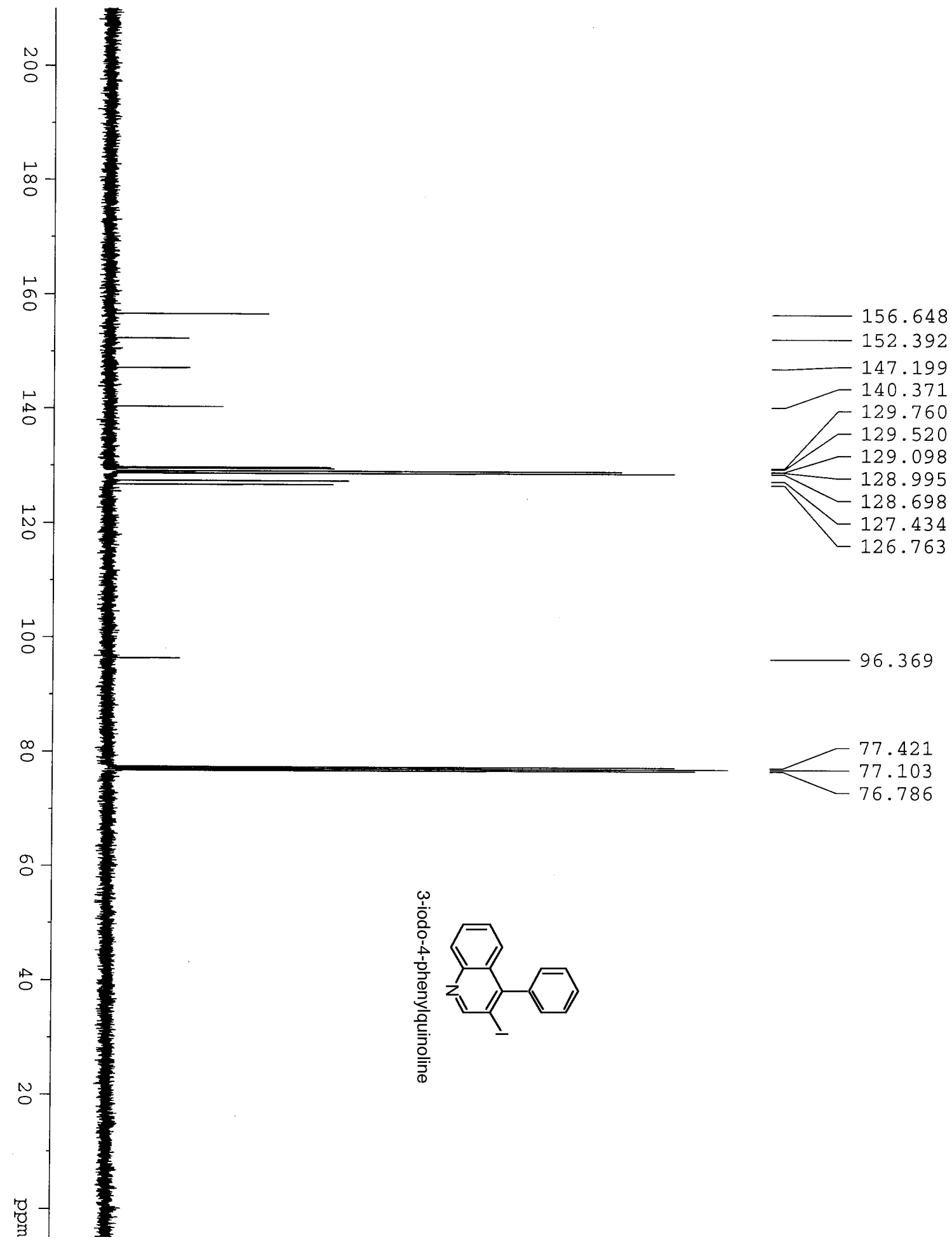




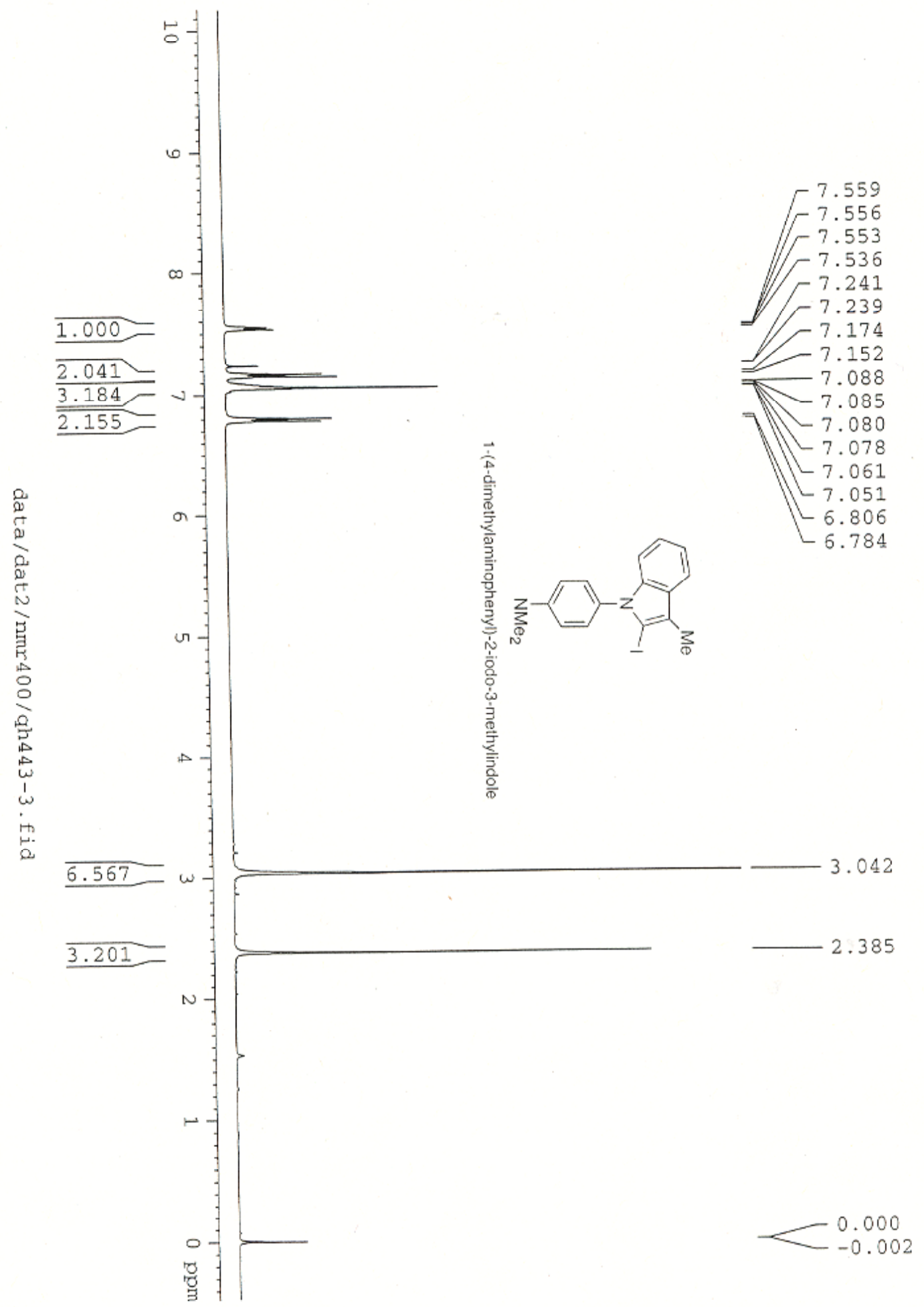




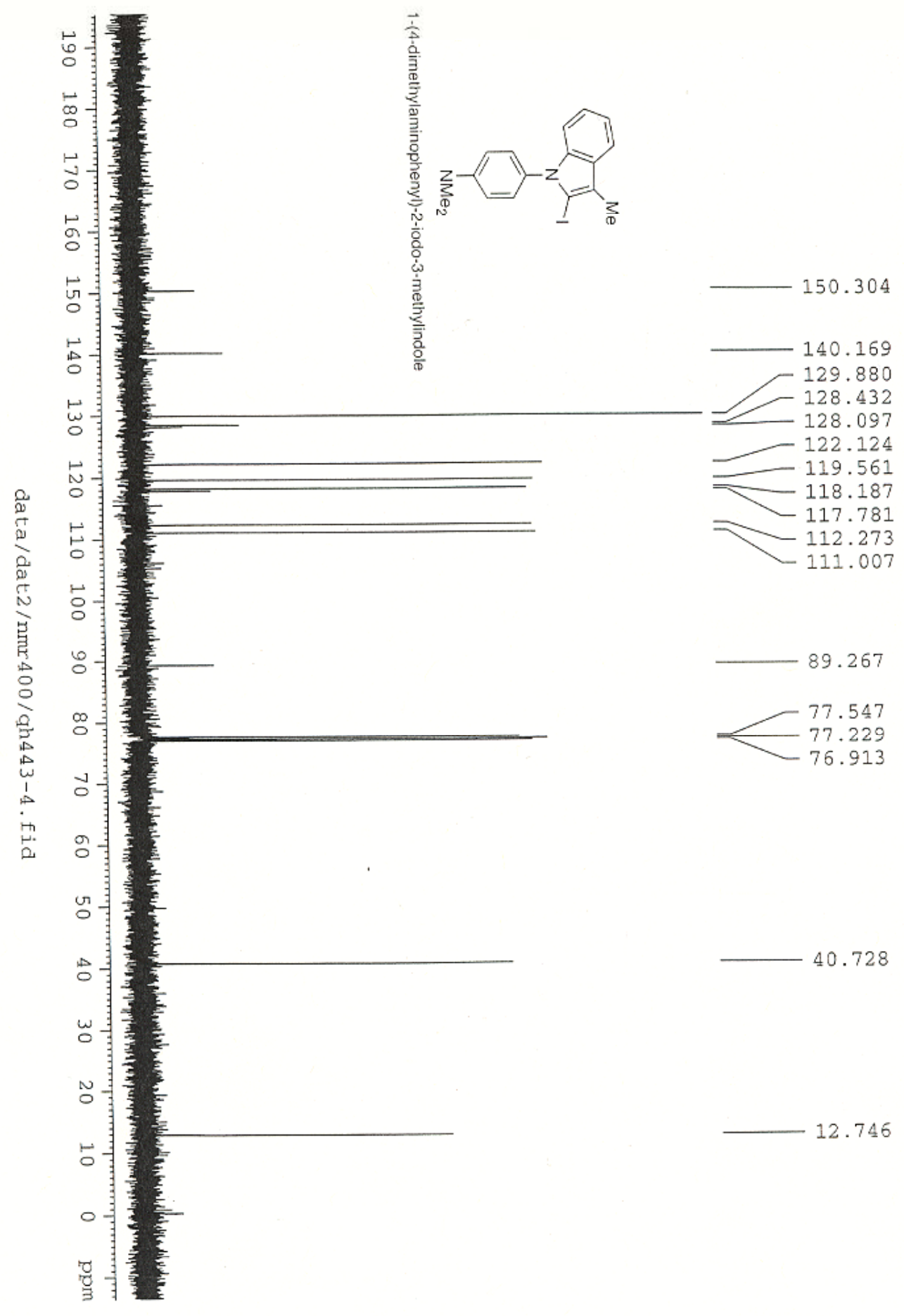




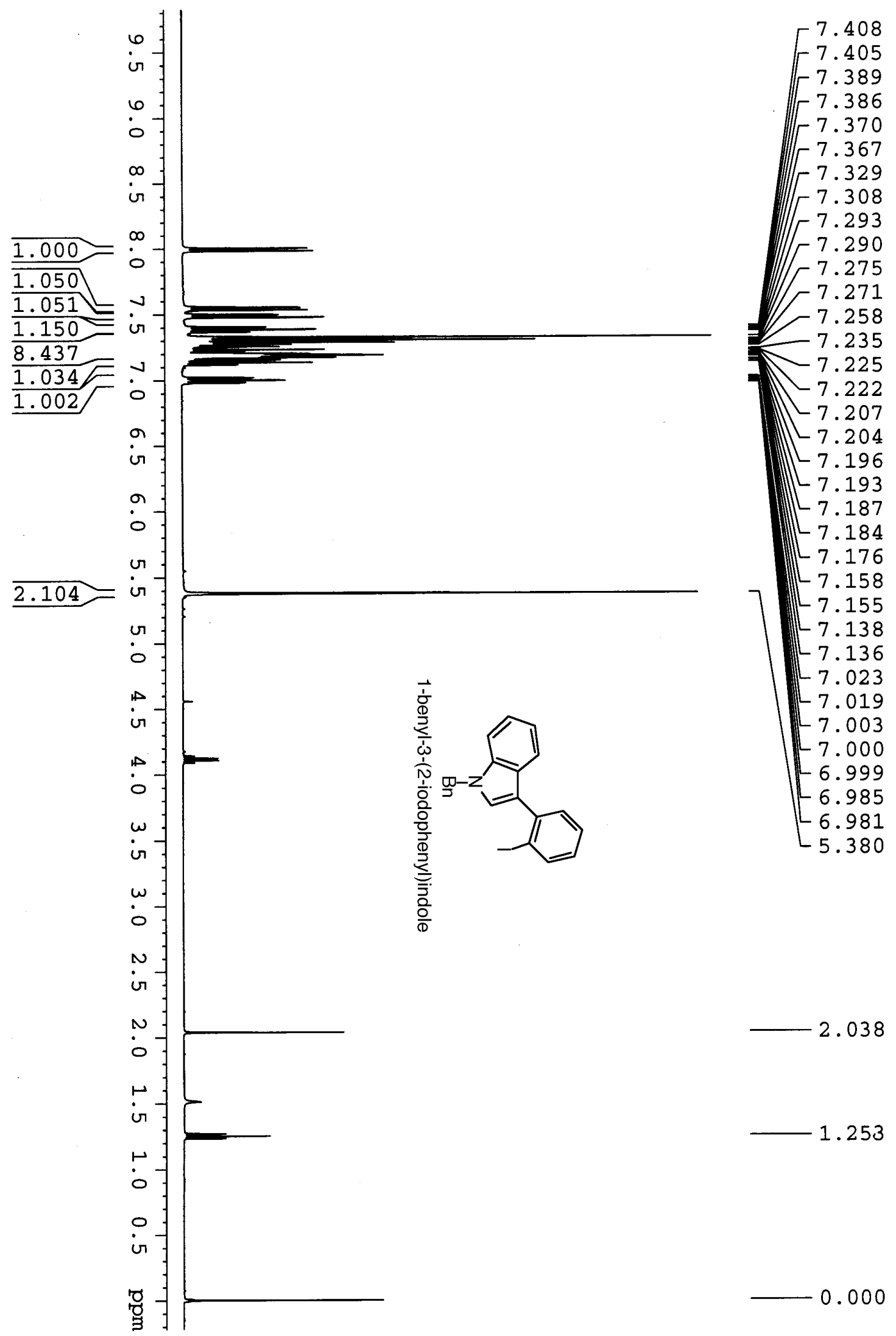




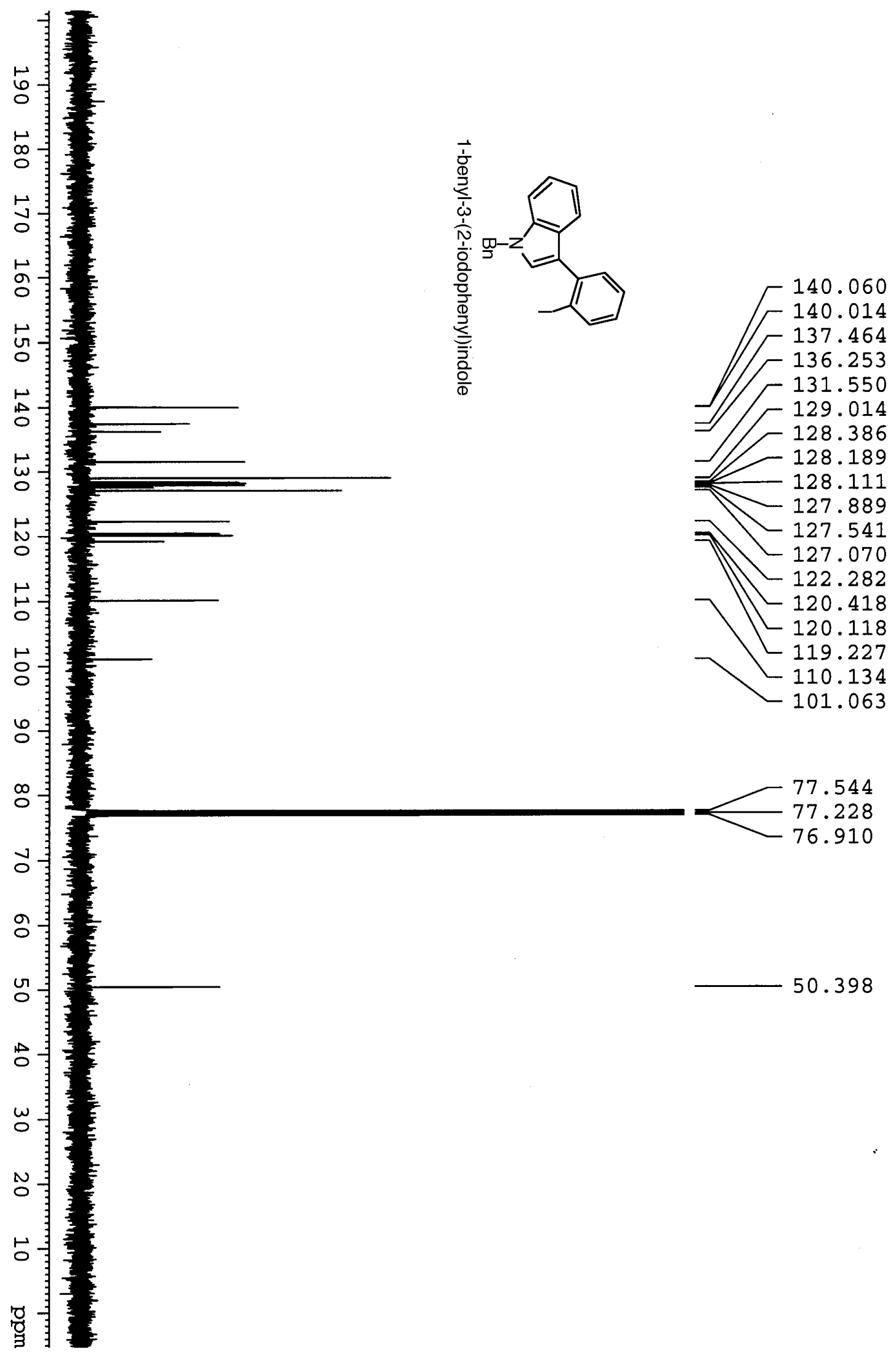




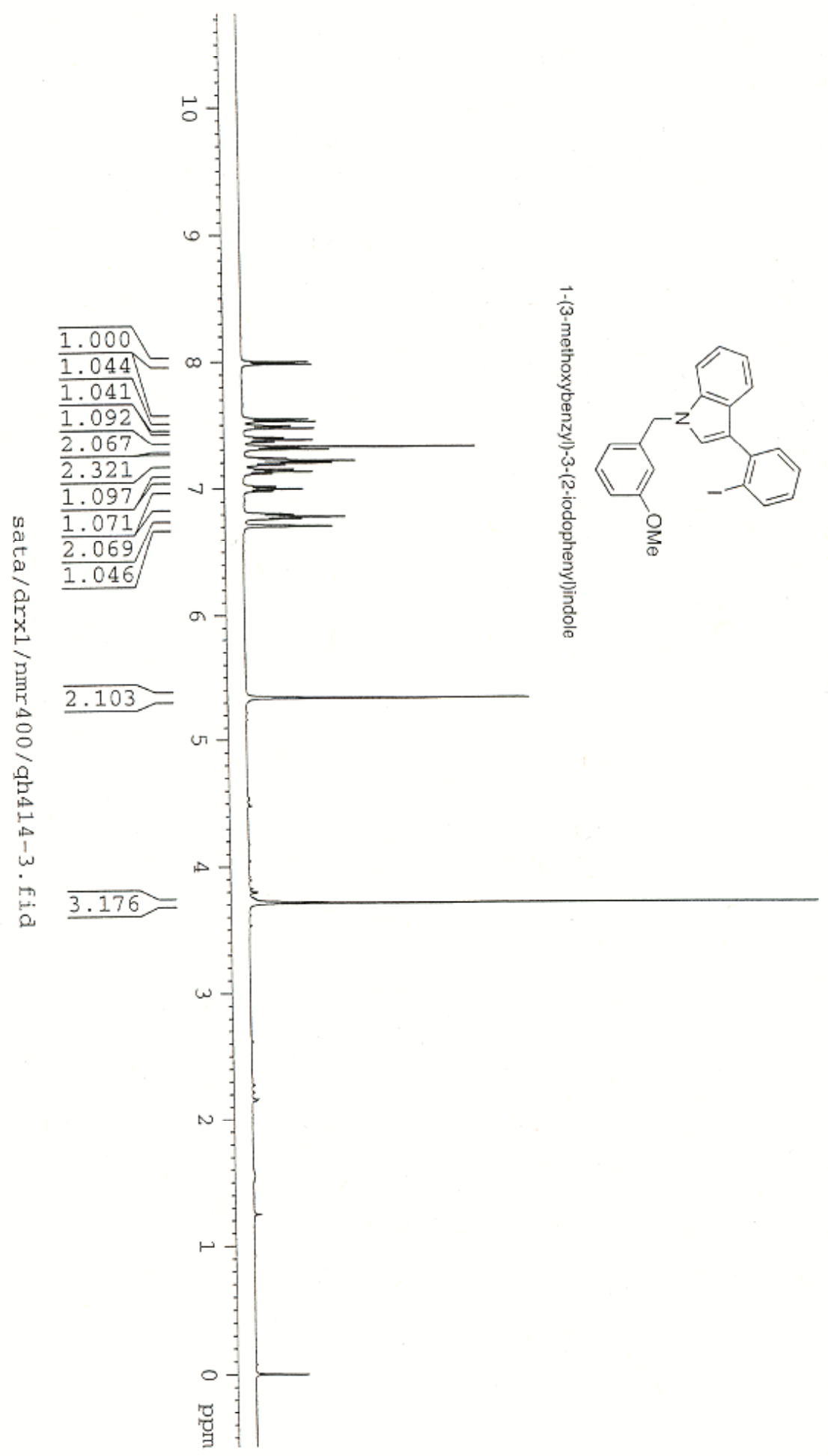

$-8.002$

$-7.982$

$-7.550$

$-7.530$

$-7.497$

$-7.494$

$-7.478$

$-7.475$

$-7.404$

$-7.385$

$-7.367$

$y-7.326$

$-7.305$

$-7.237$

$-7.226$

$-7.199$

$\longrightarrow 7.183$

$7 \mid-7.151$

$M-7.133$

$-7.115$

$-7.020$

$-7.016$

$-7.000$

$-6.982$

ㄴ. 6.978

䟝 6.806

勋 6.801

L 6.786

L 6.767

L 6.711

5.340

3.716

0.000 


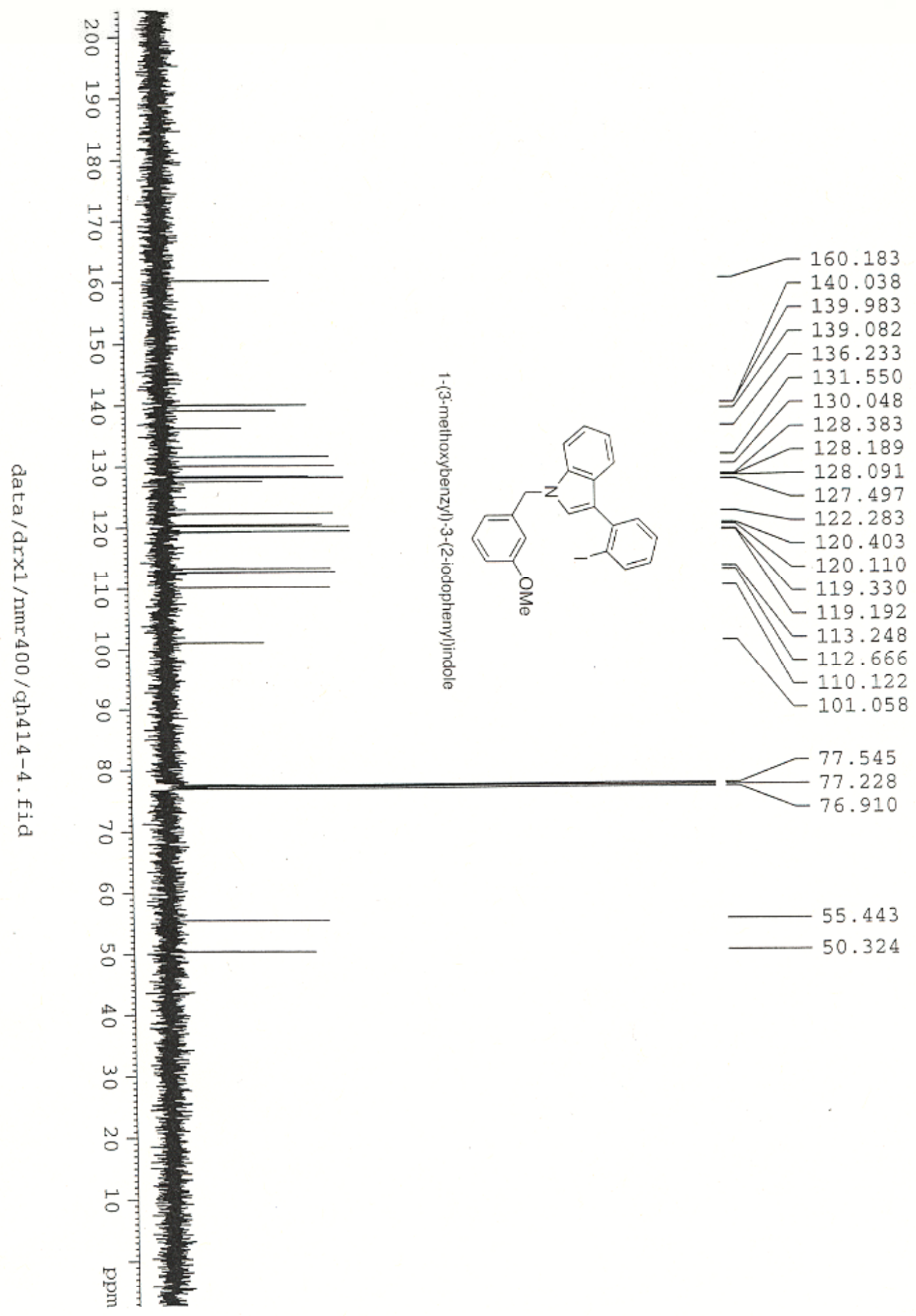




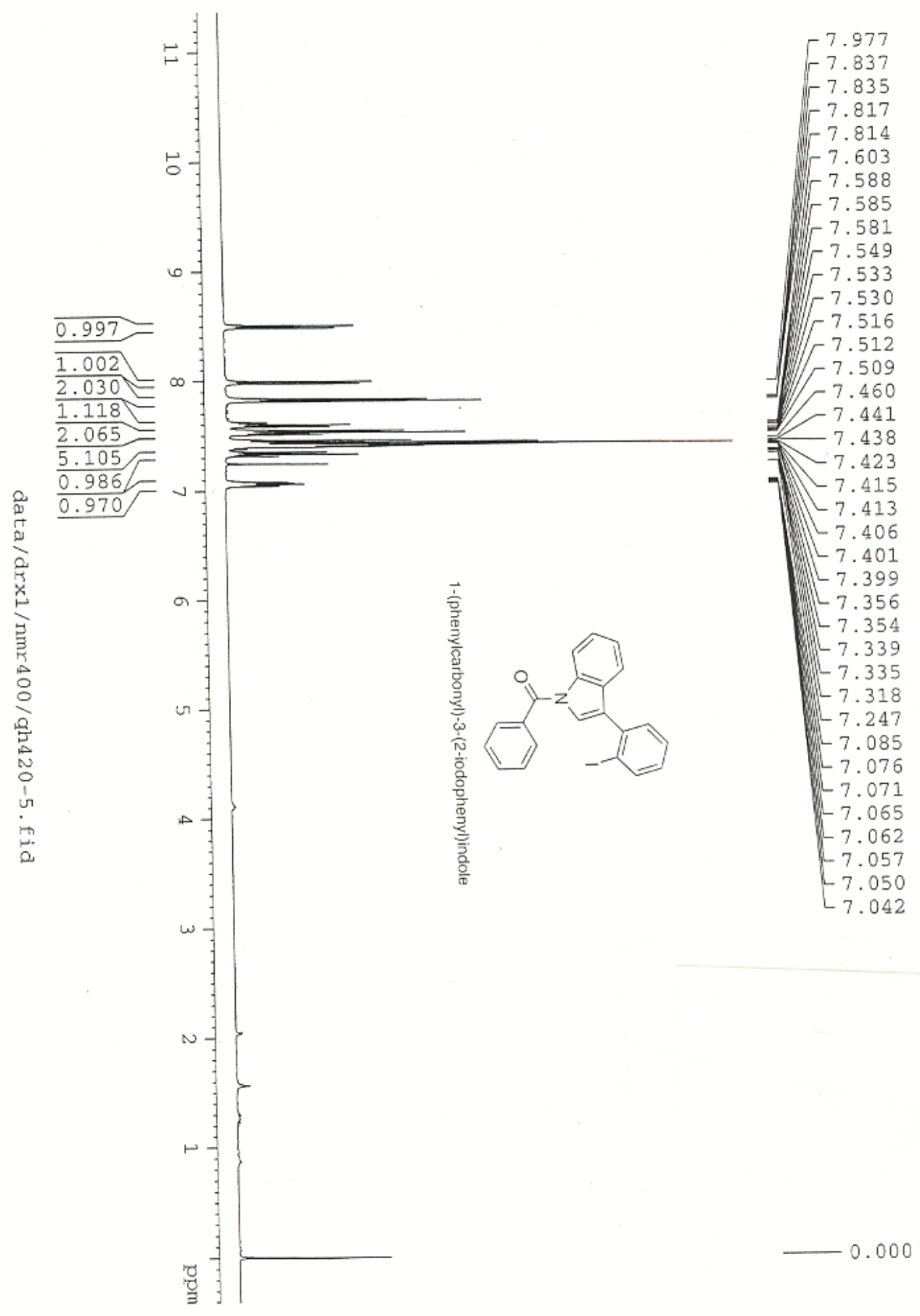




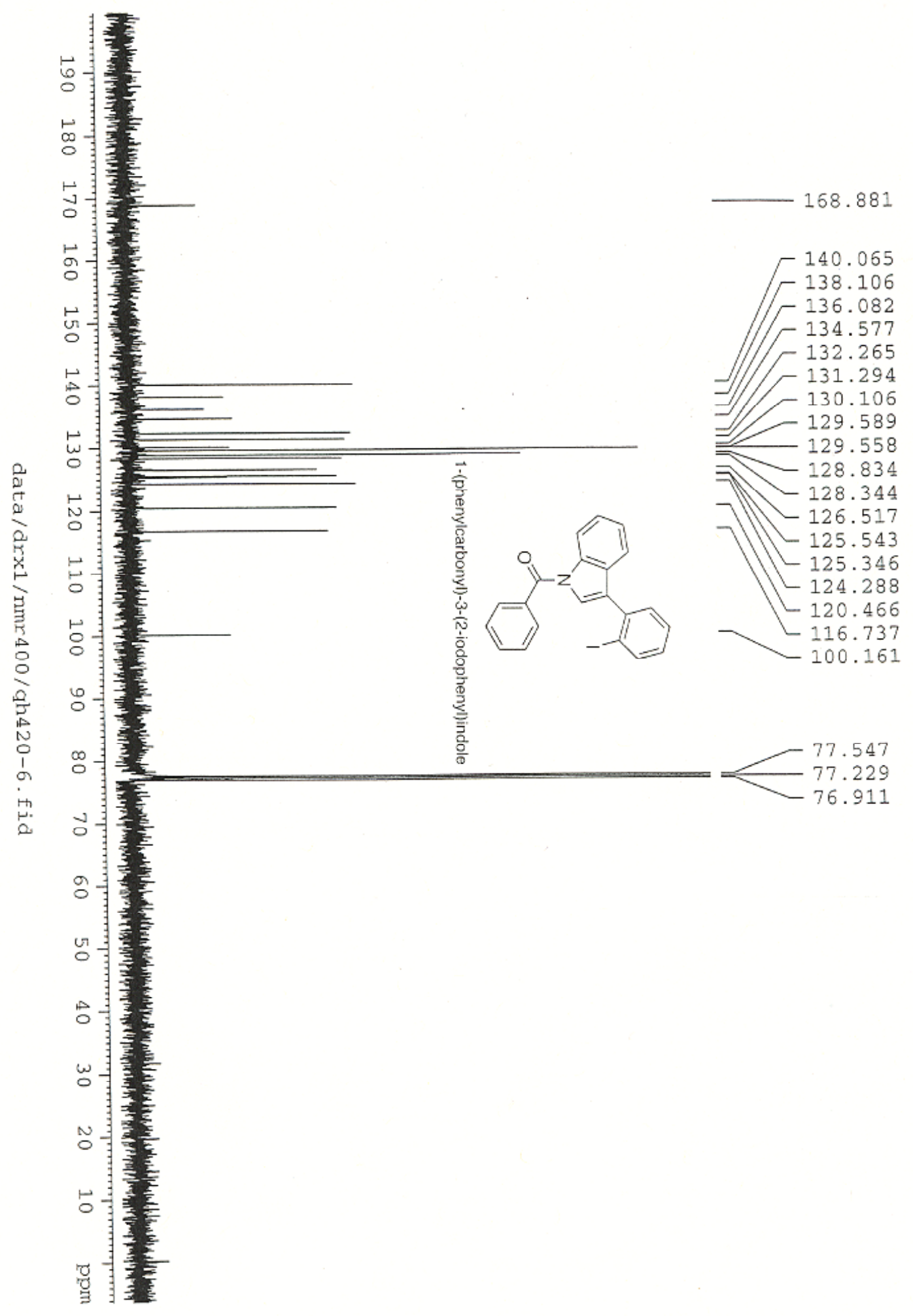




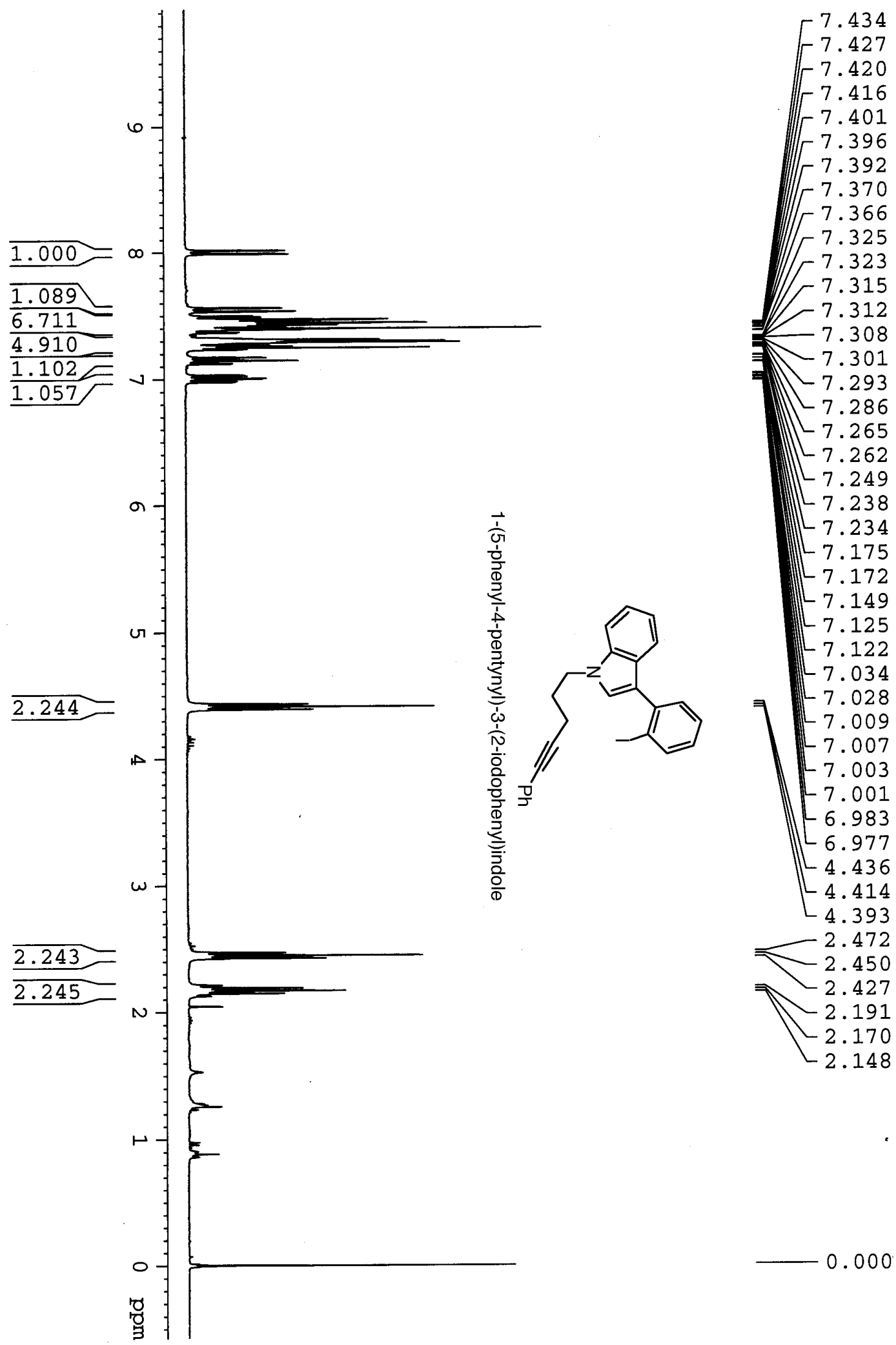



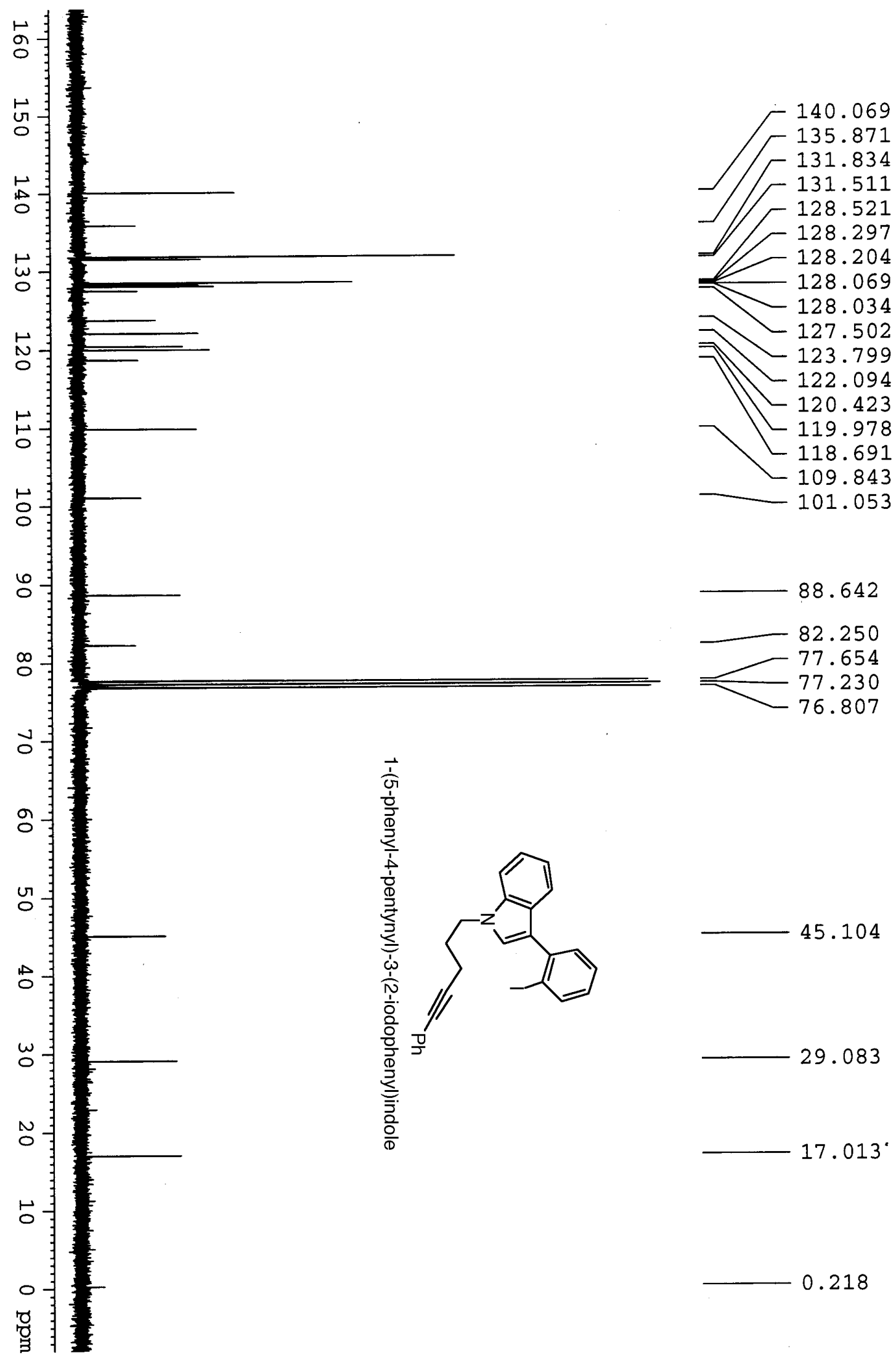

29.083

$17.013^{\circ}$

0.218 

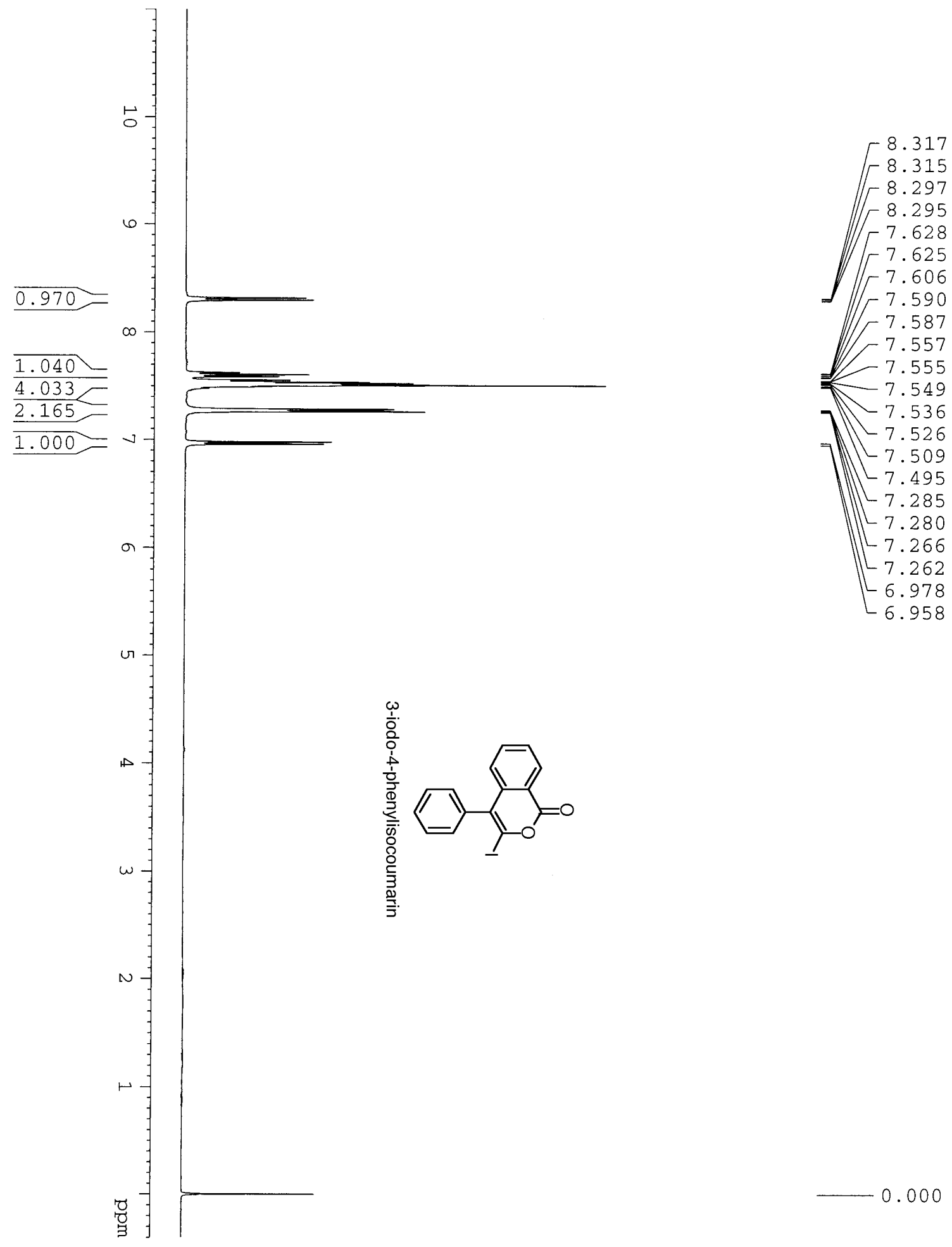


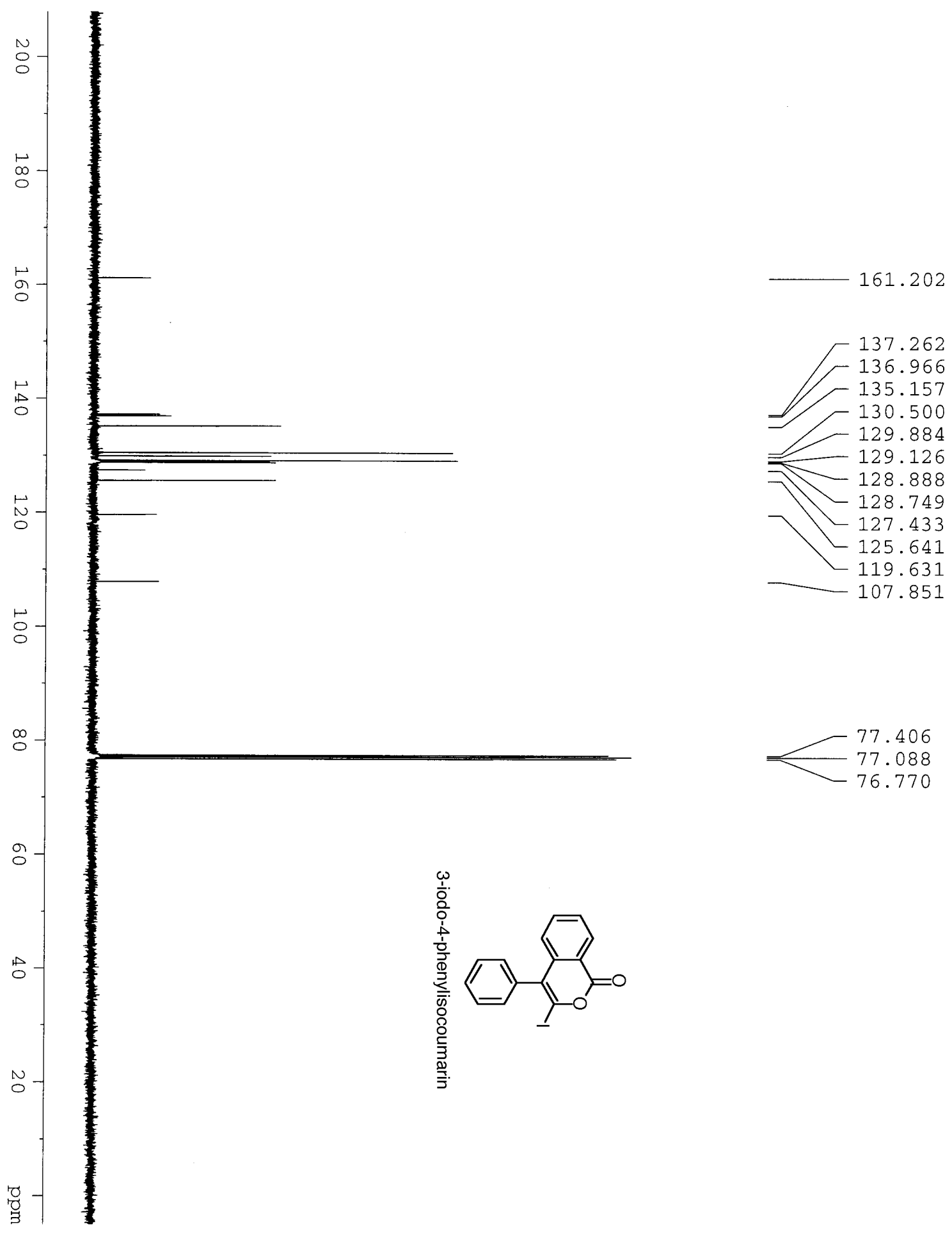



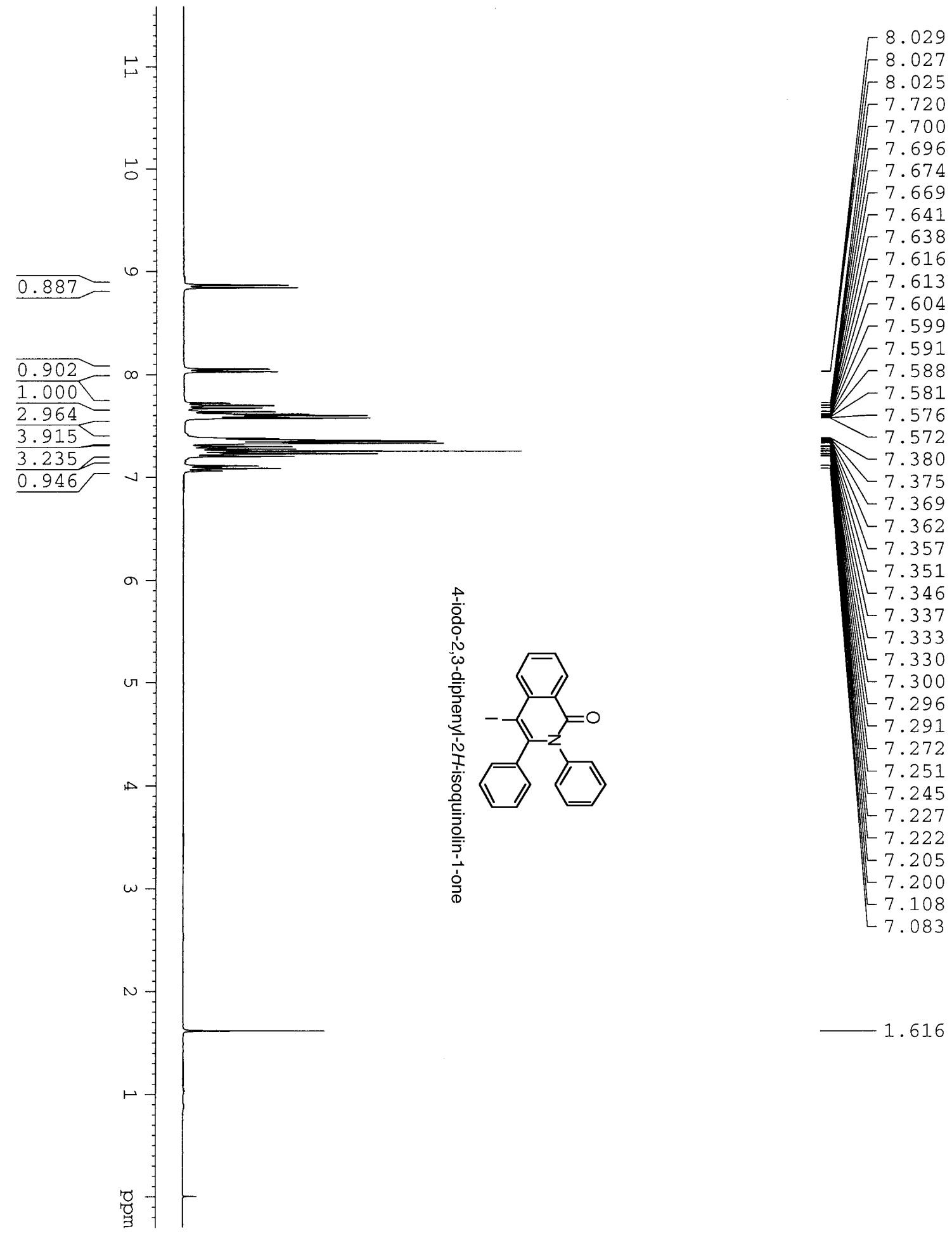


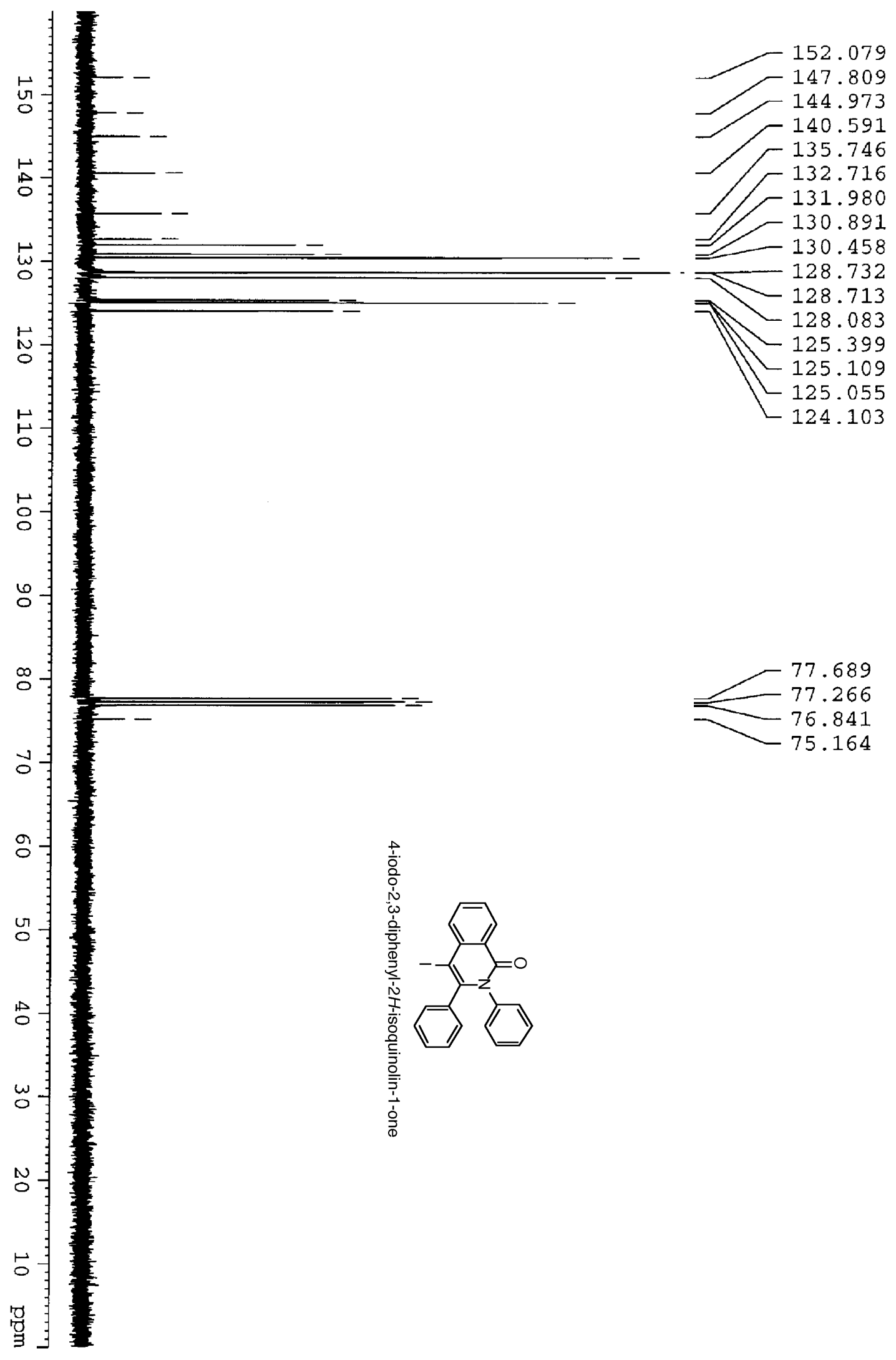




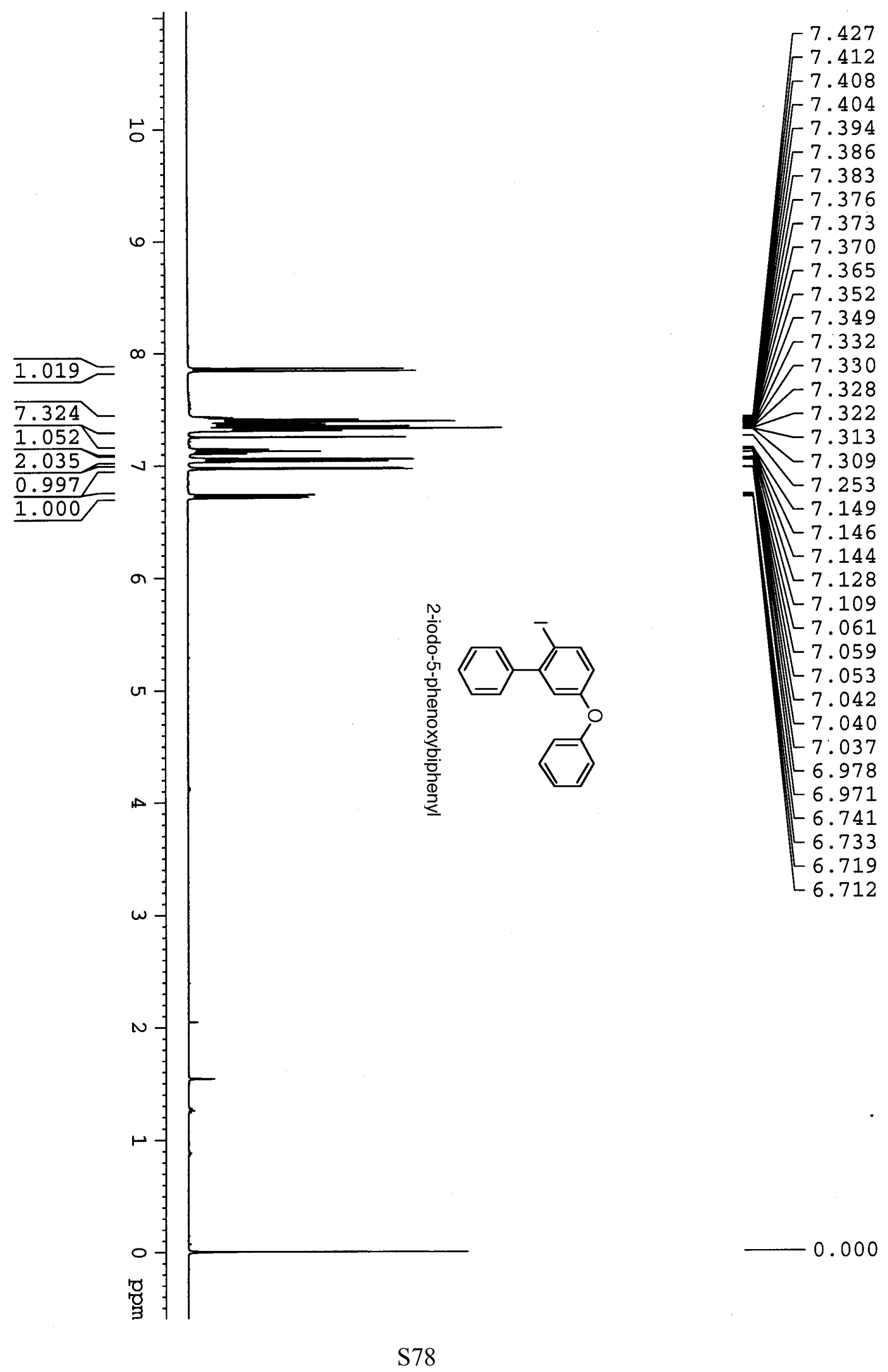




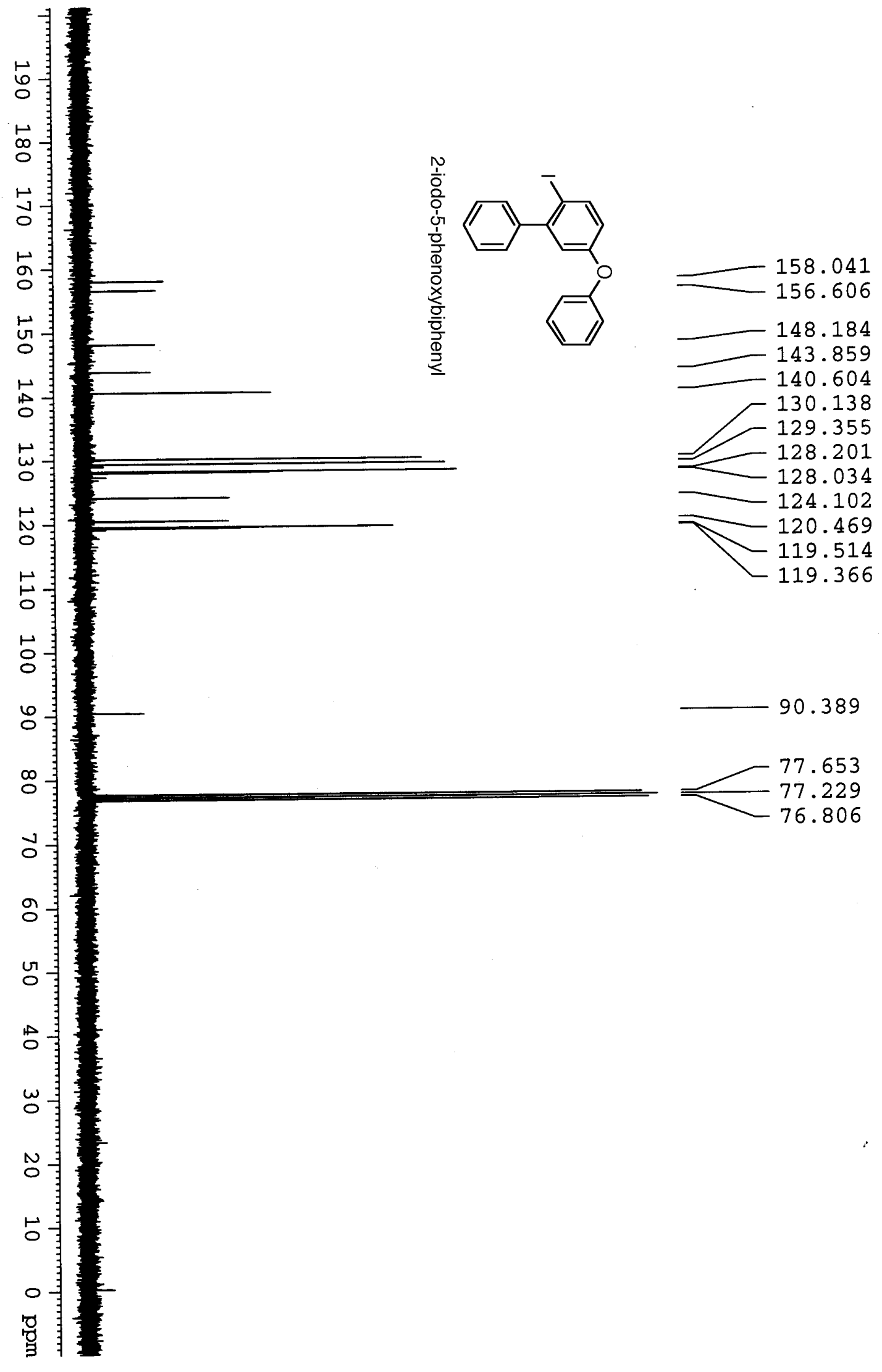




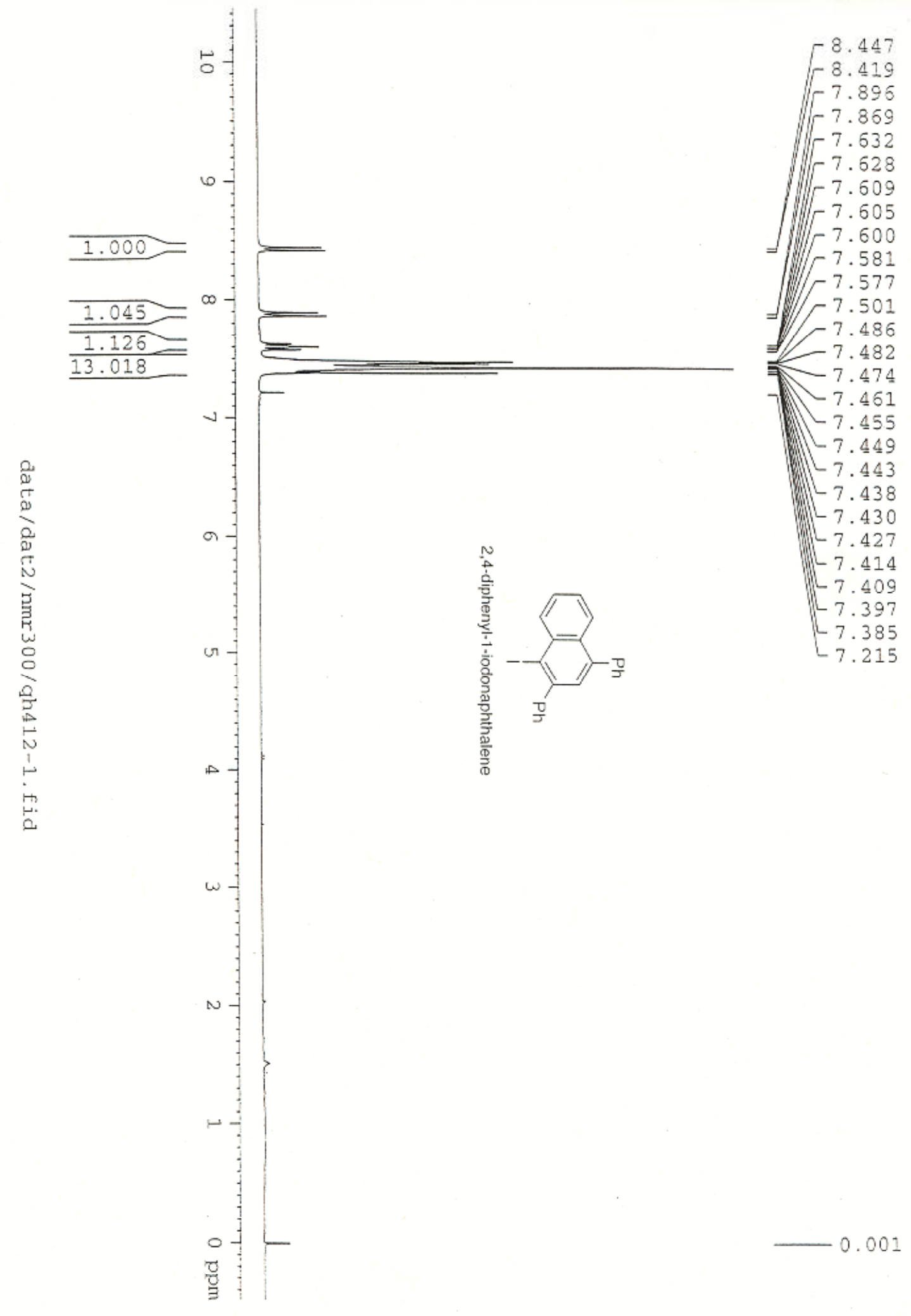




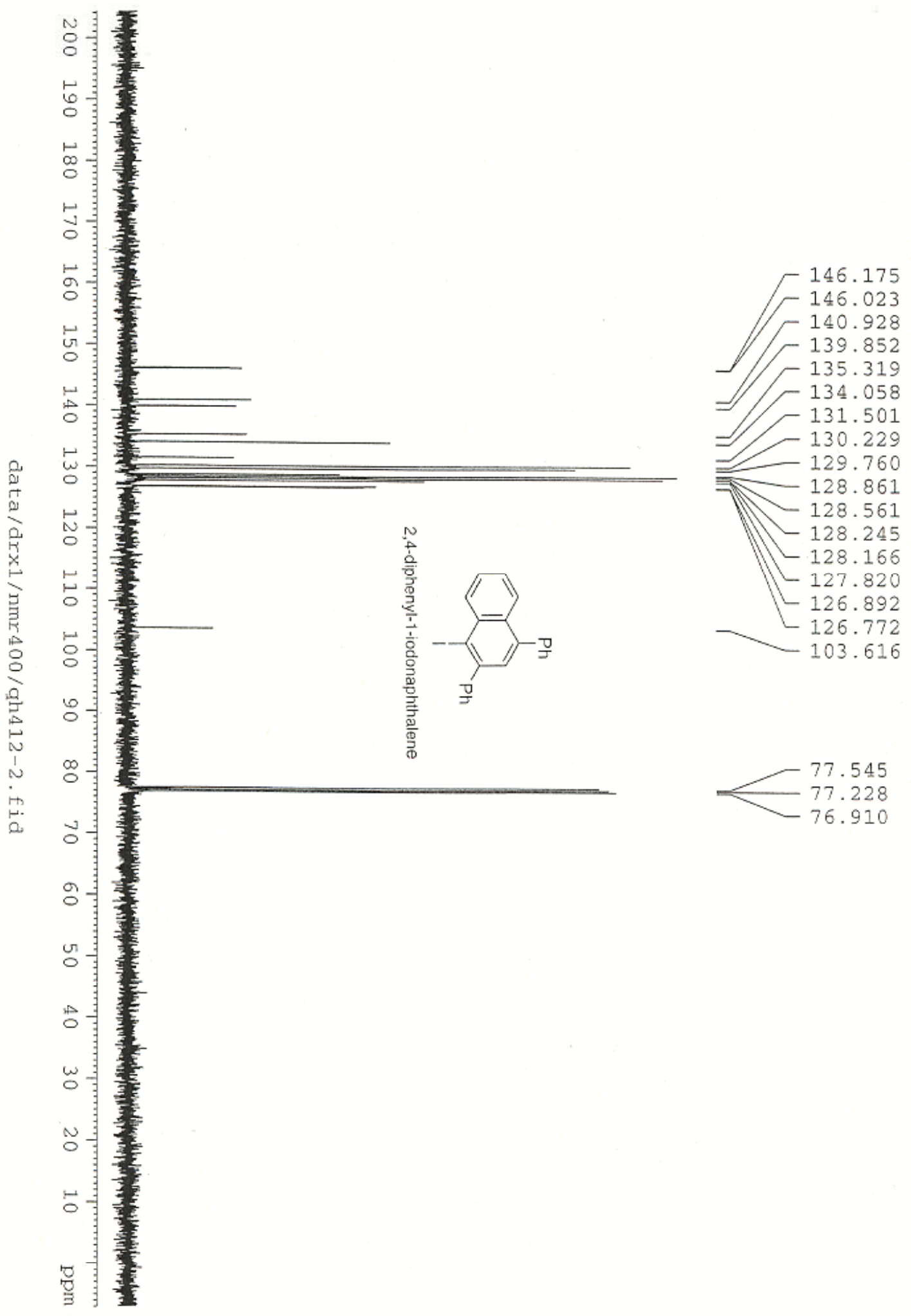



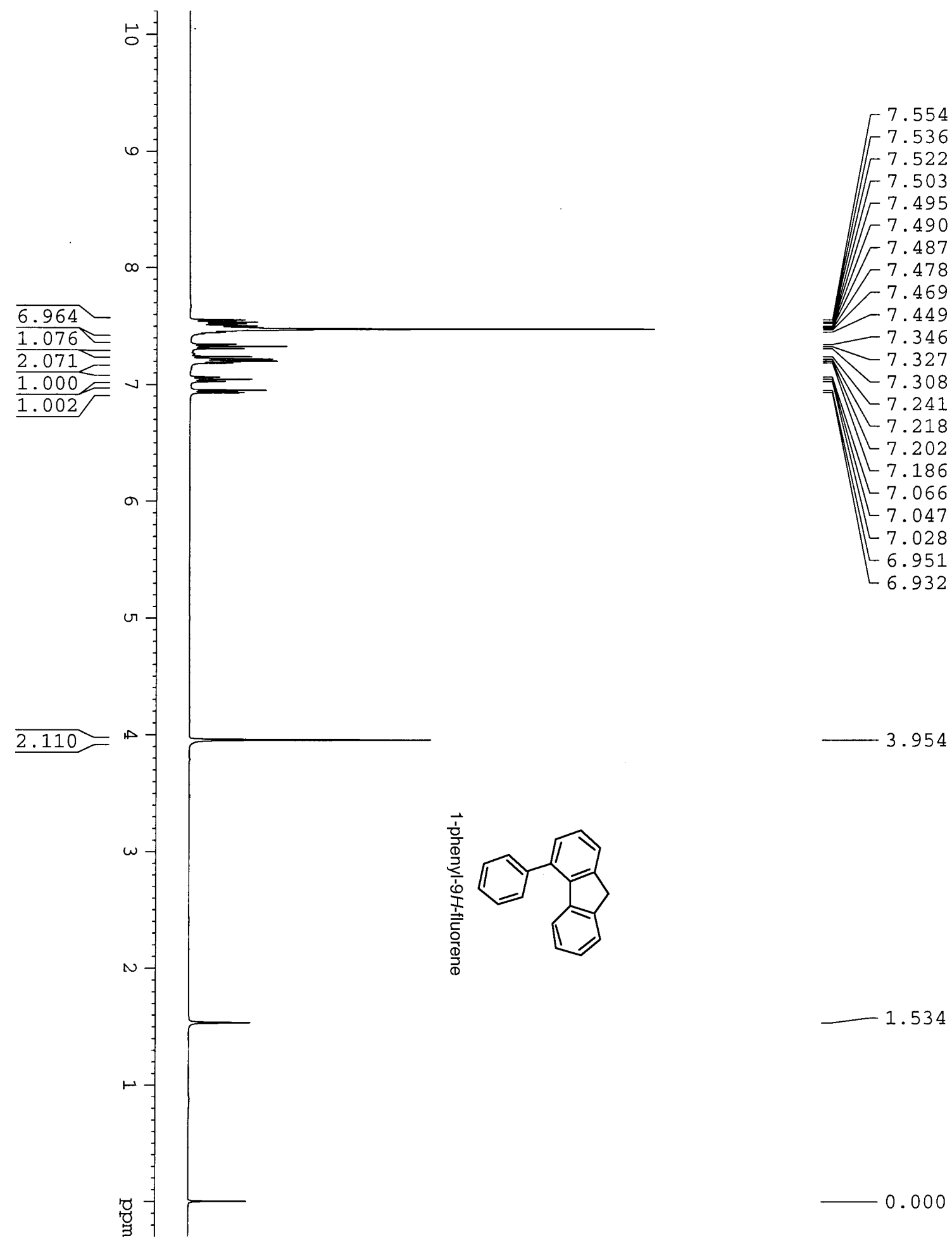

3.954 

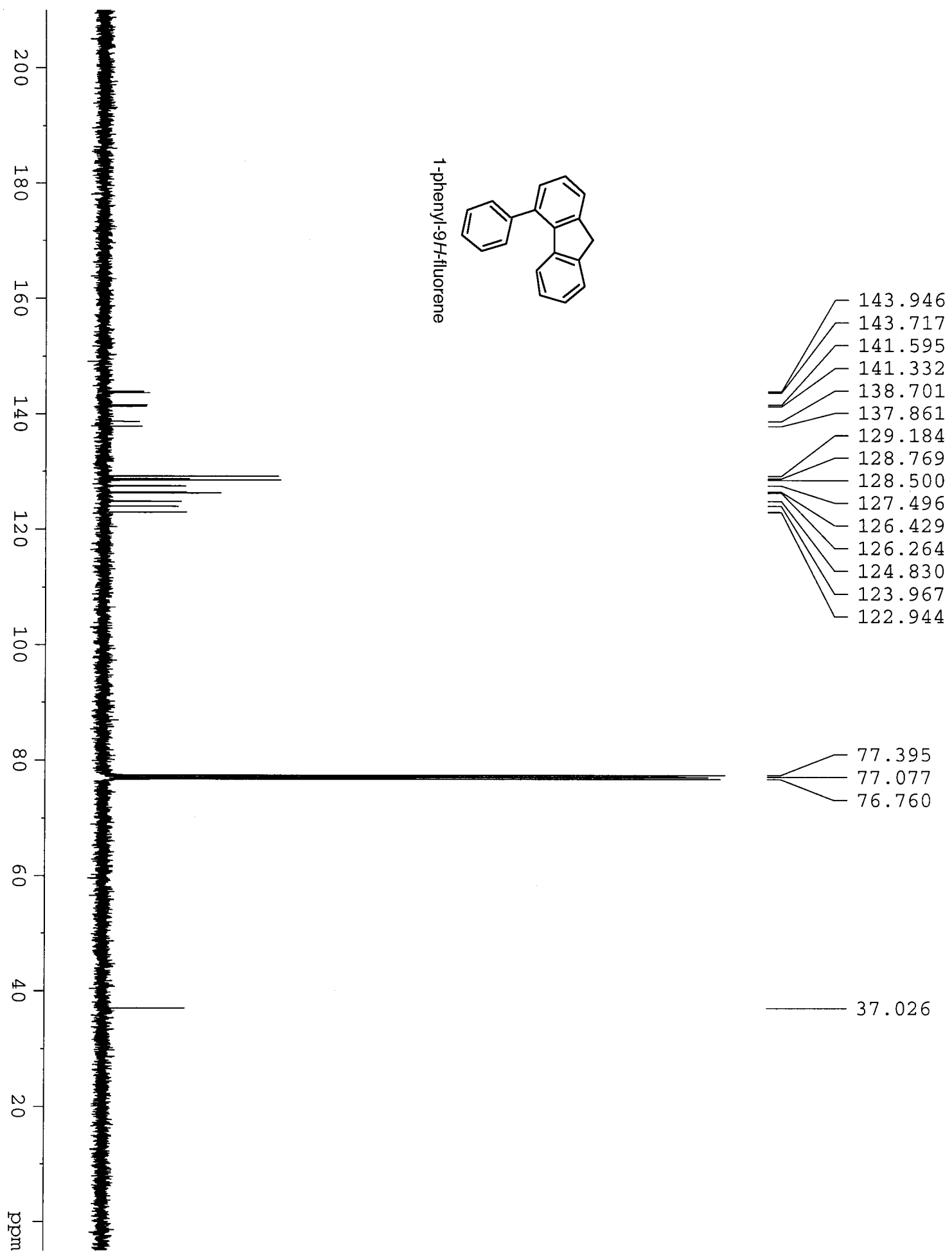

37.026 

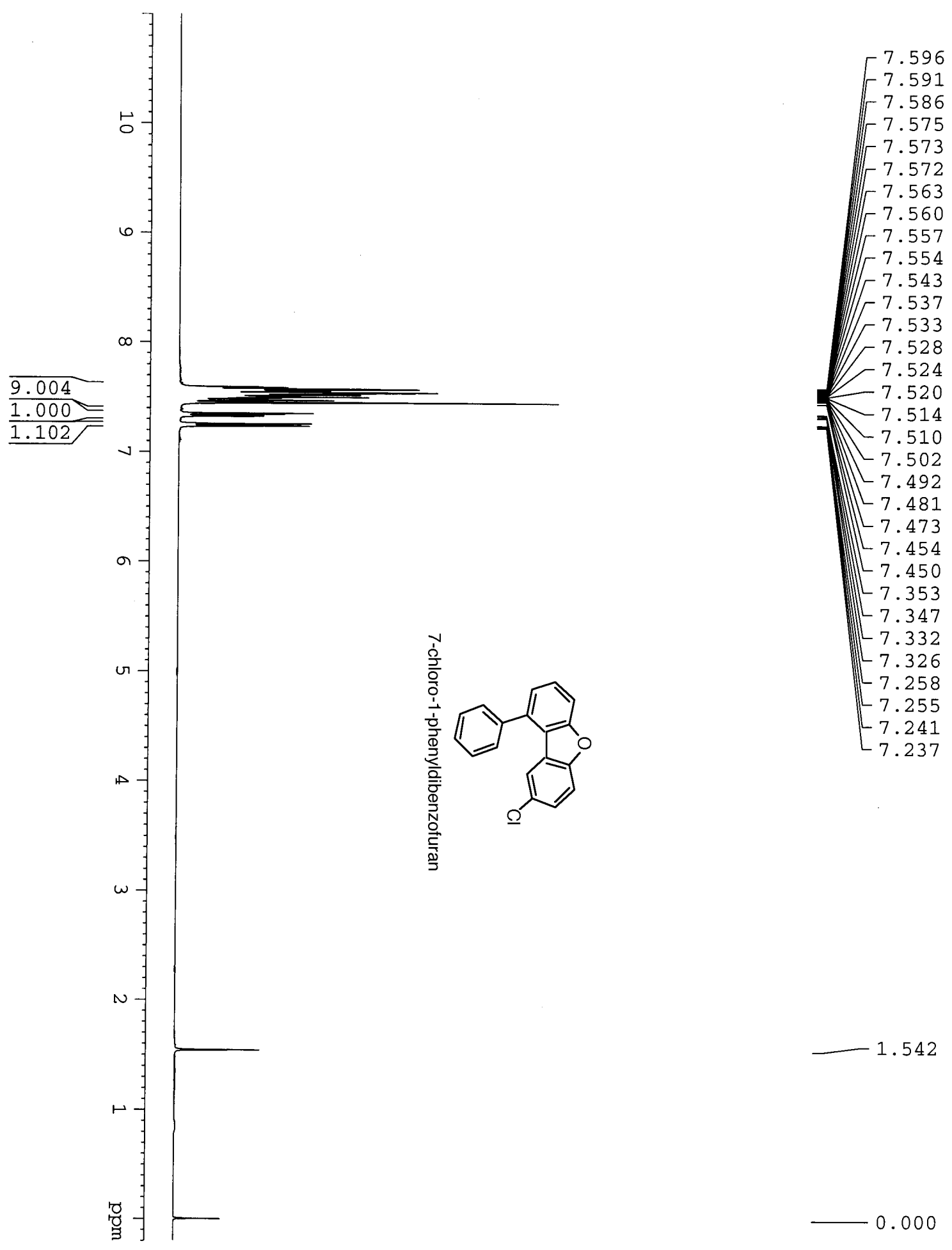

0.000 


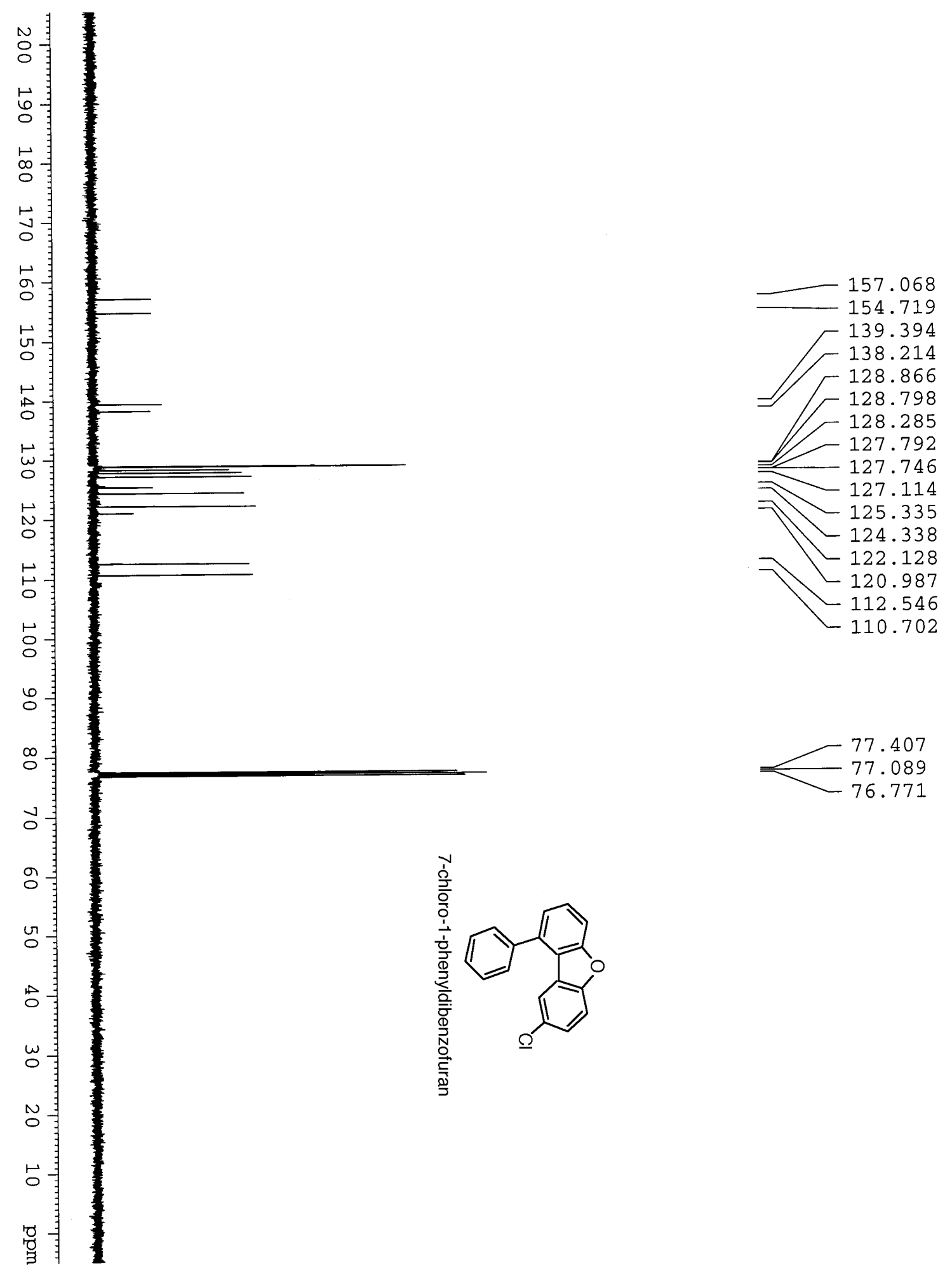



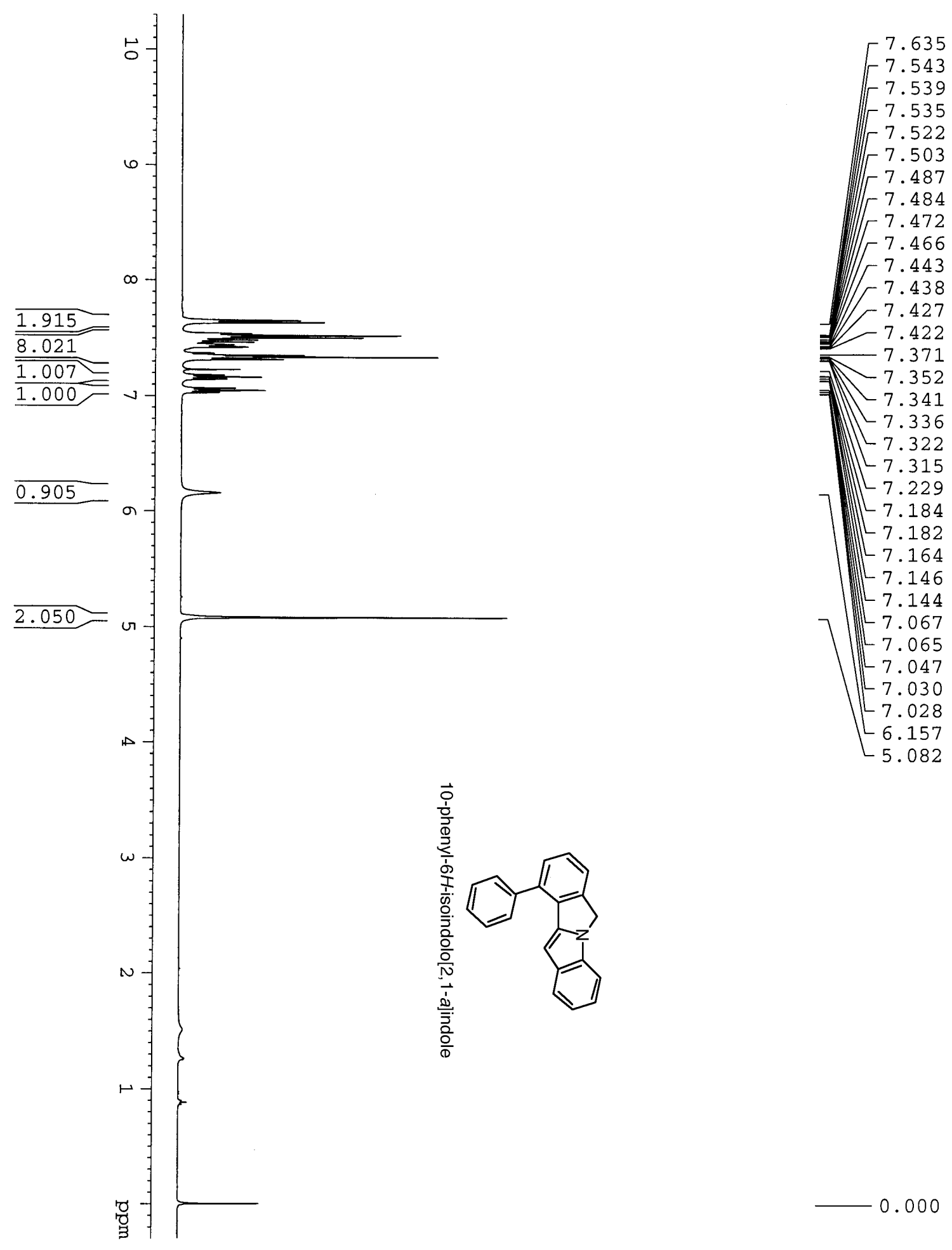

$-0.000$ 


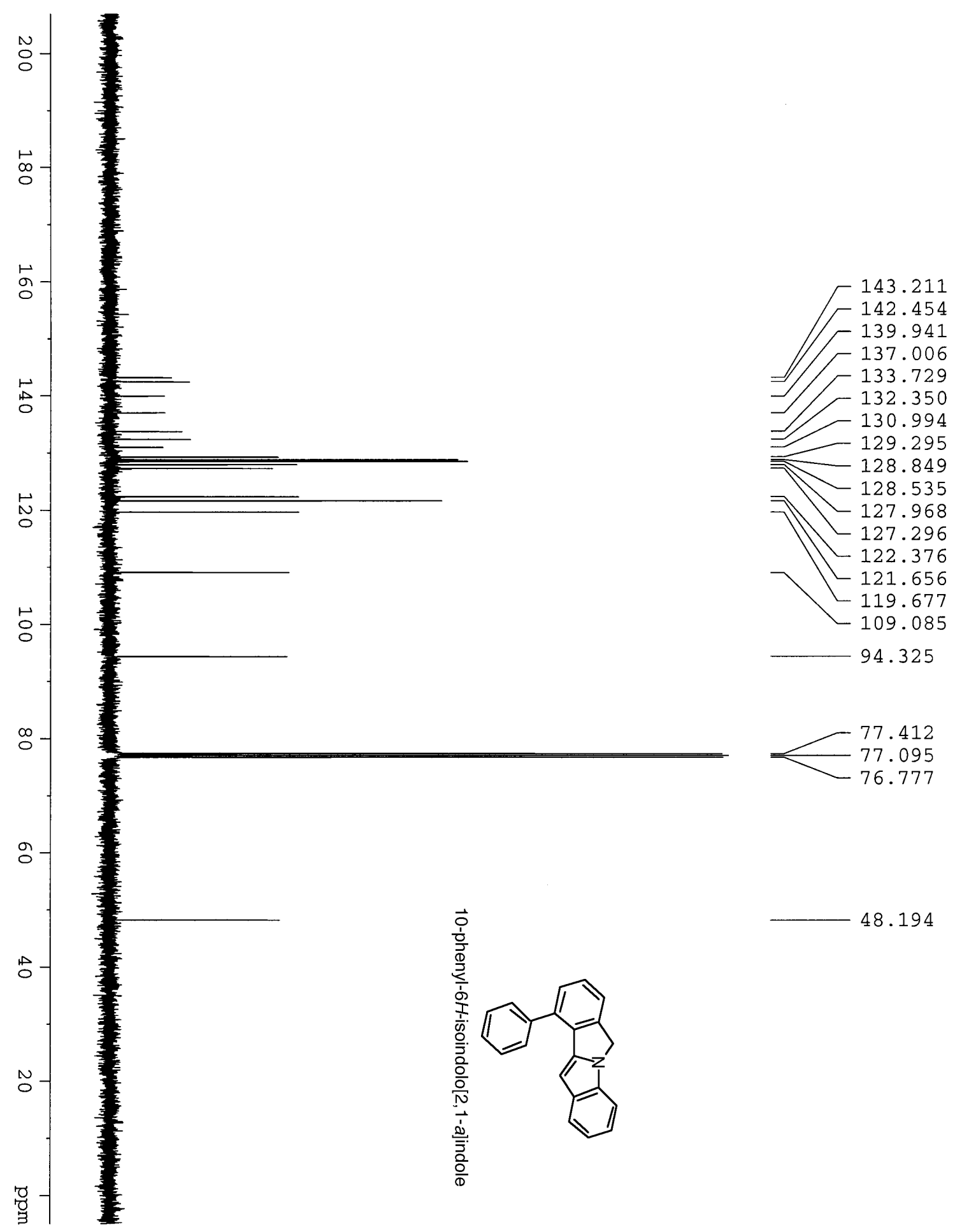




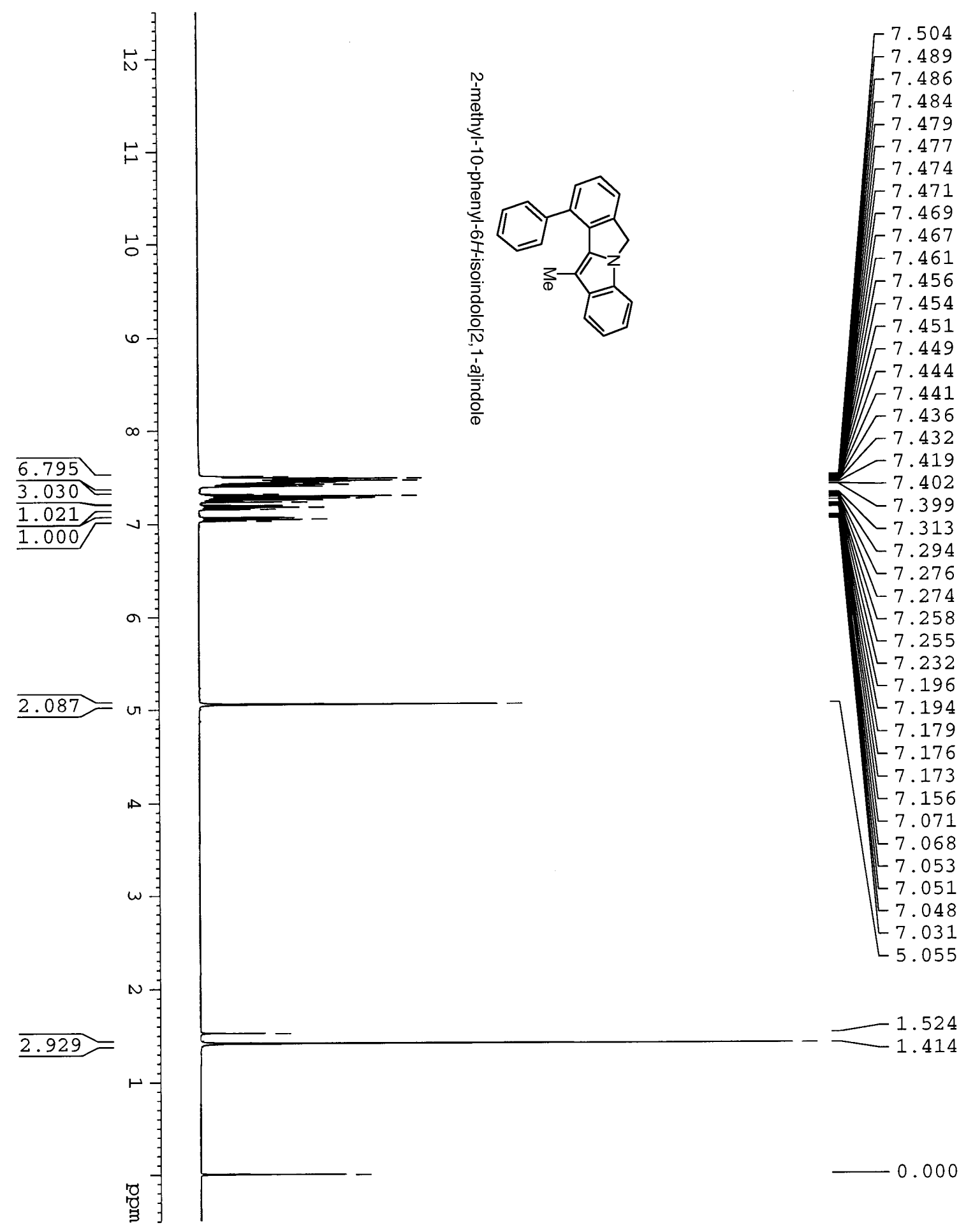




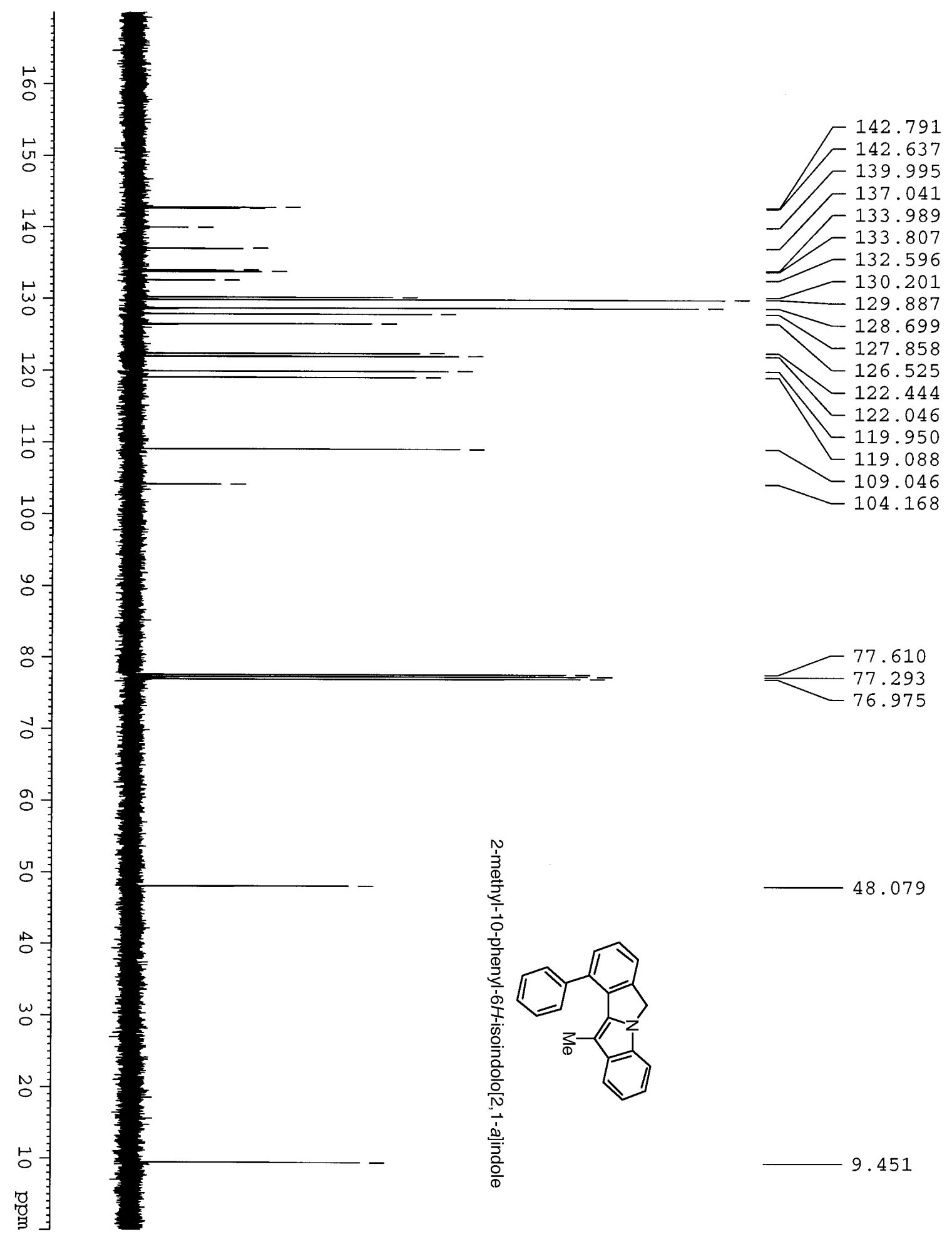




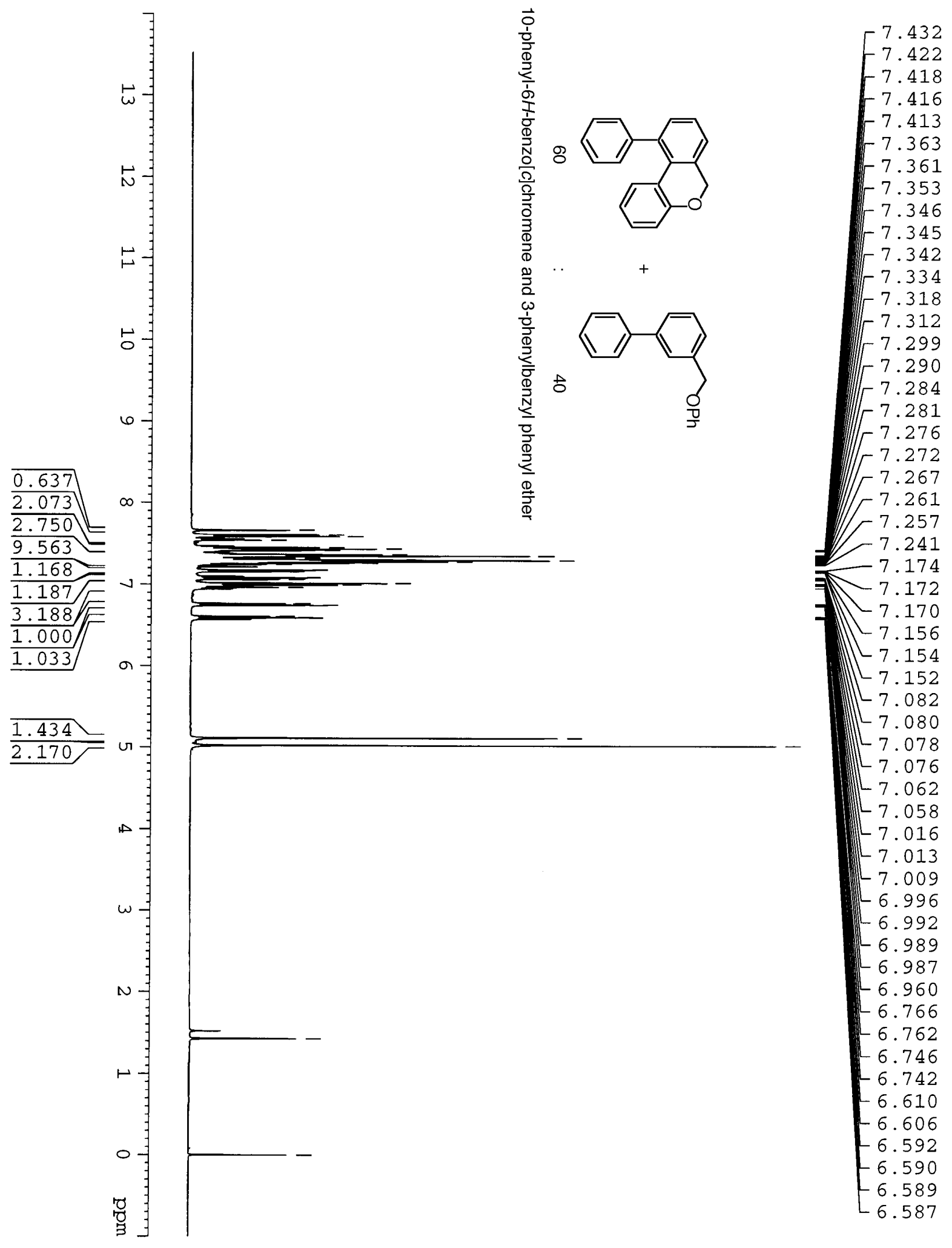




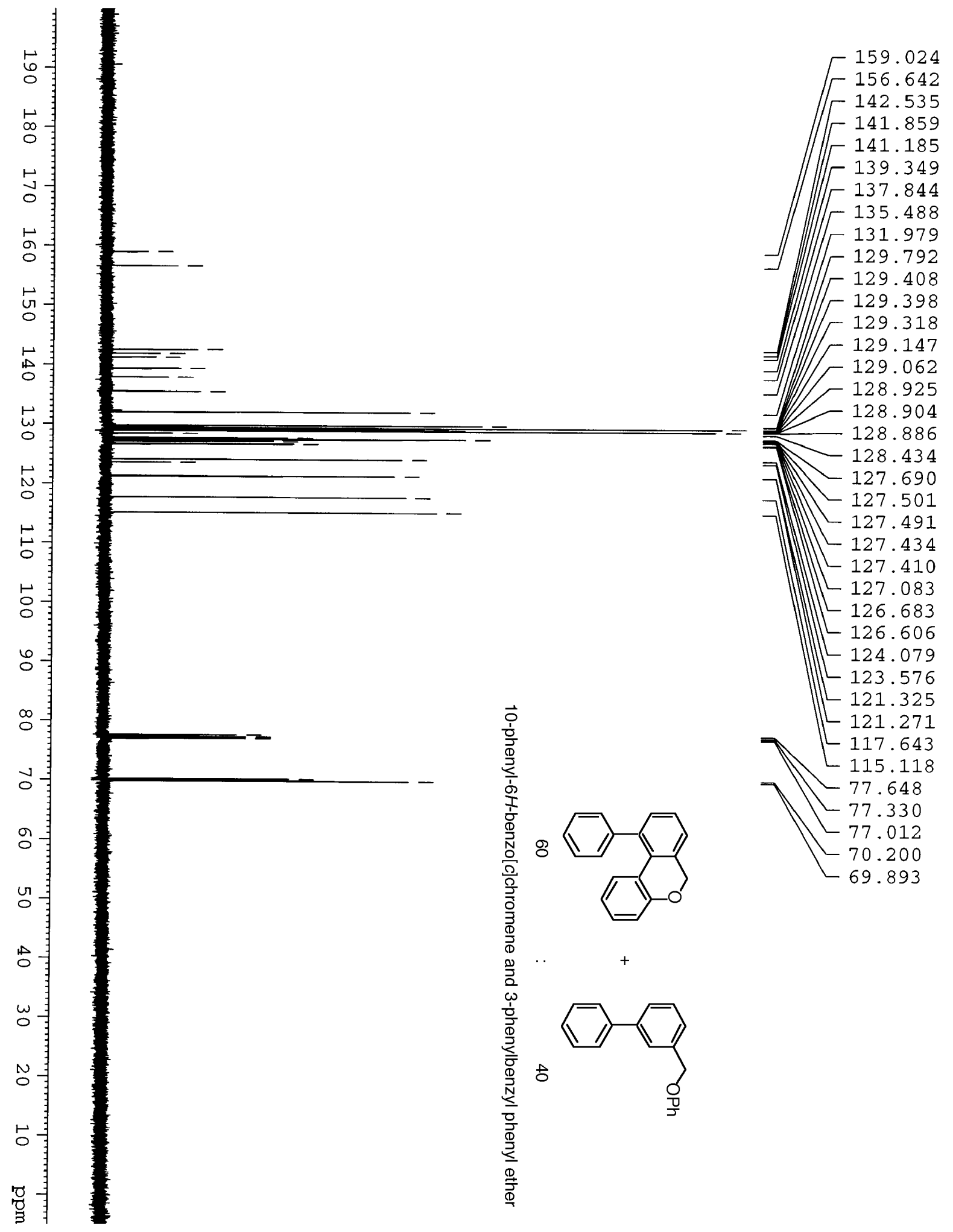



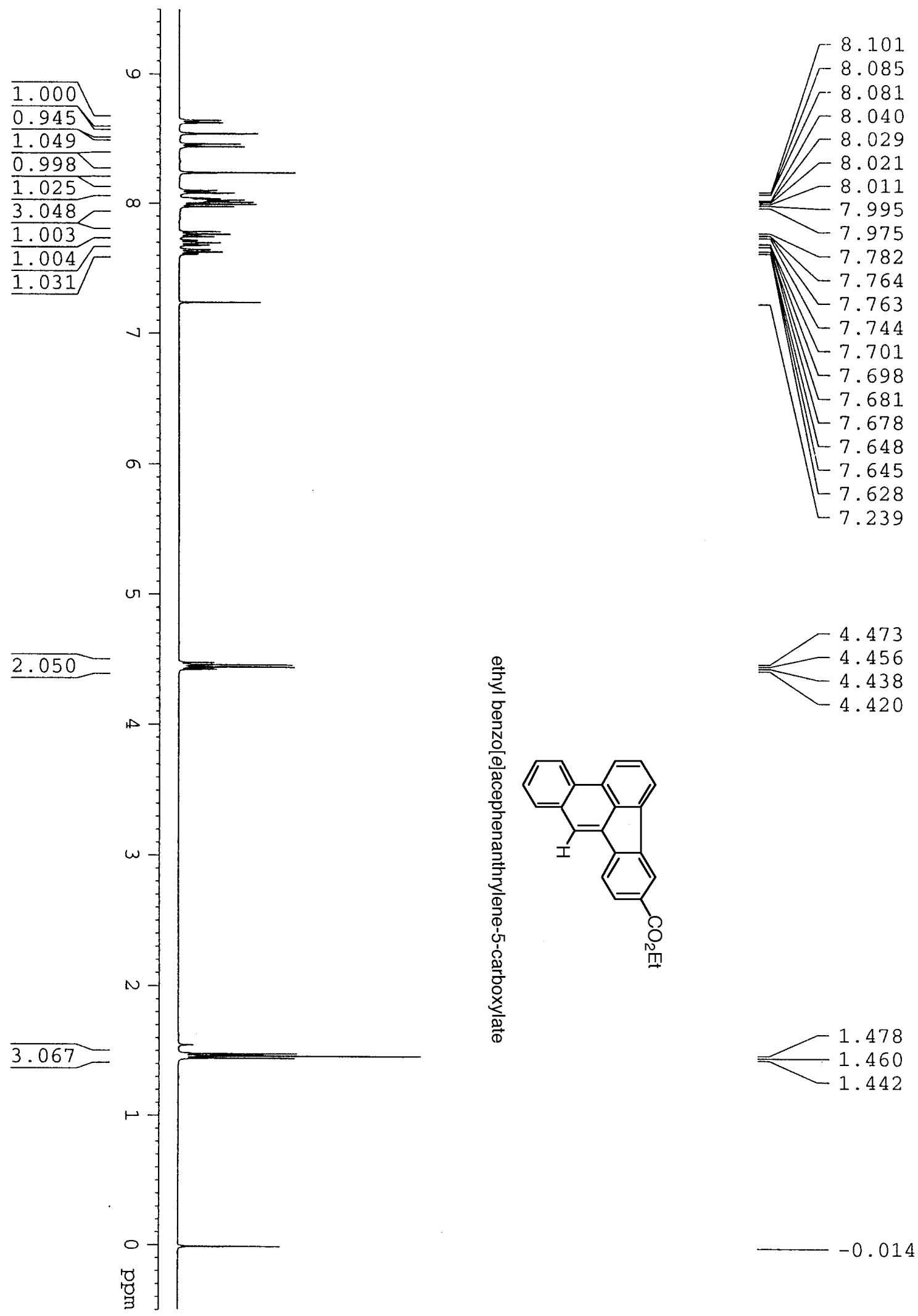


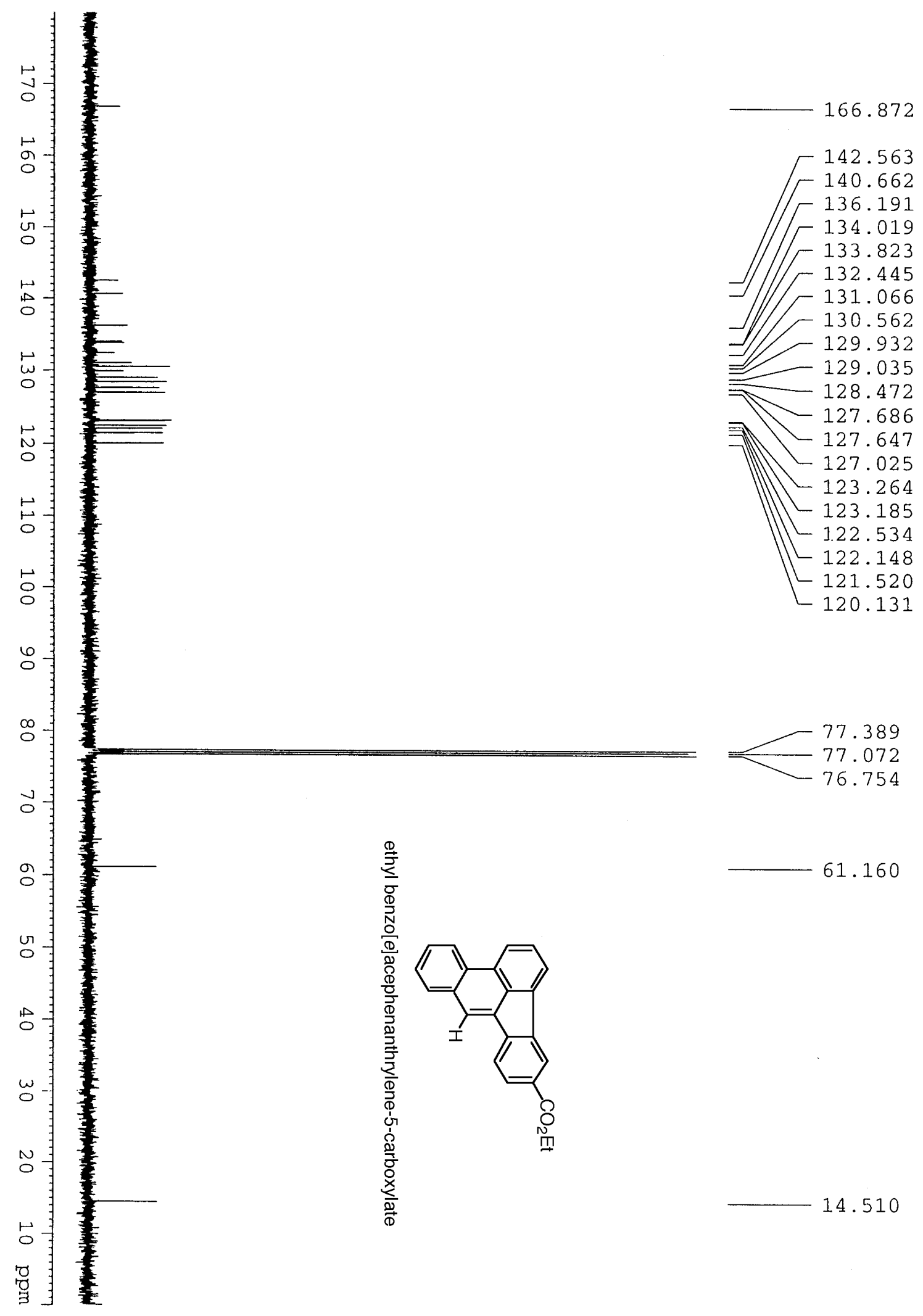



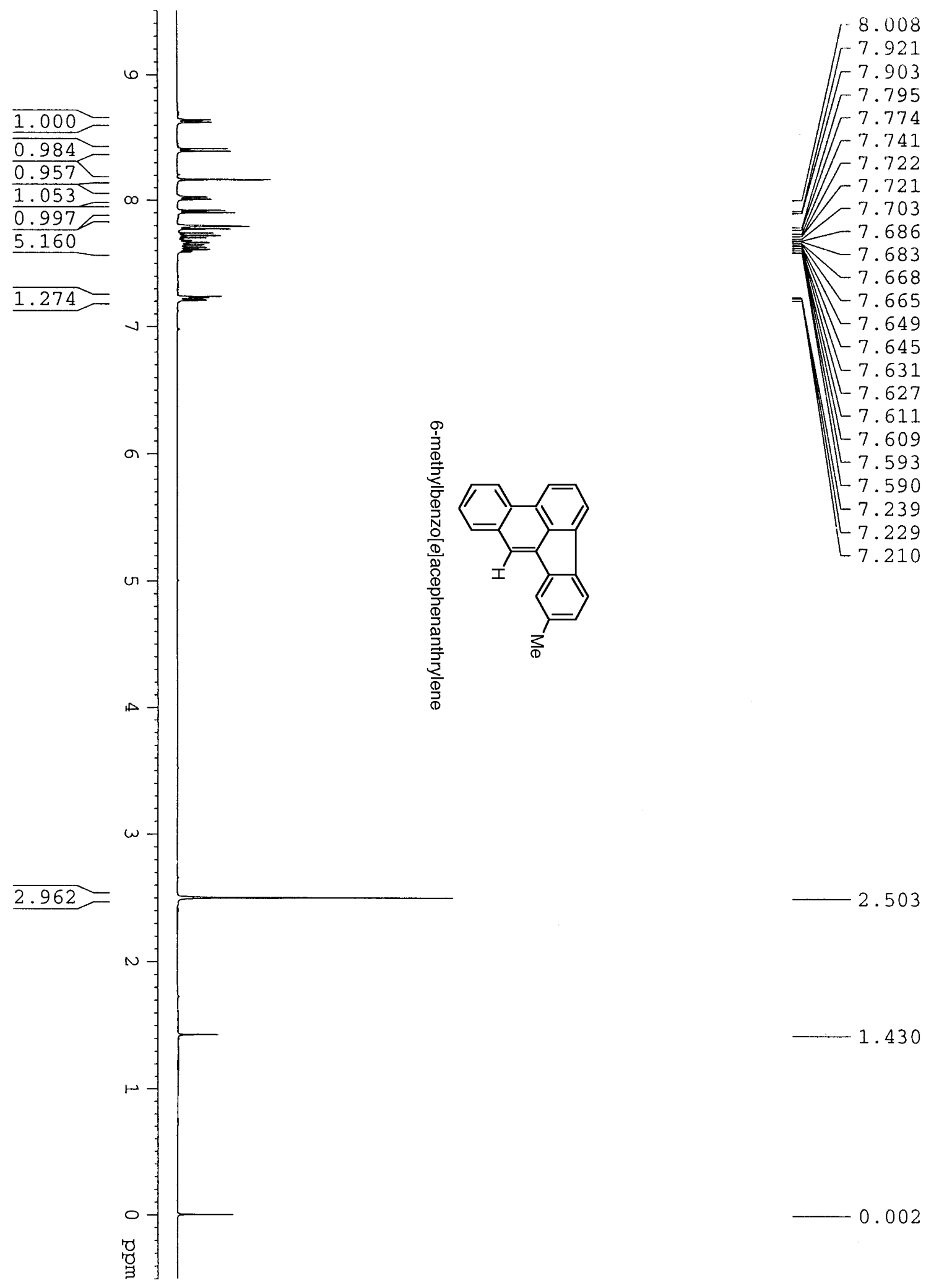

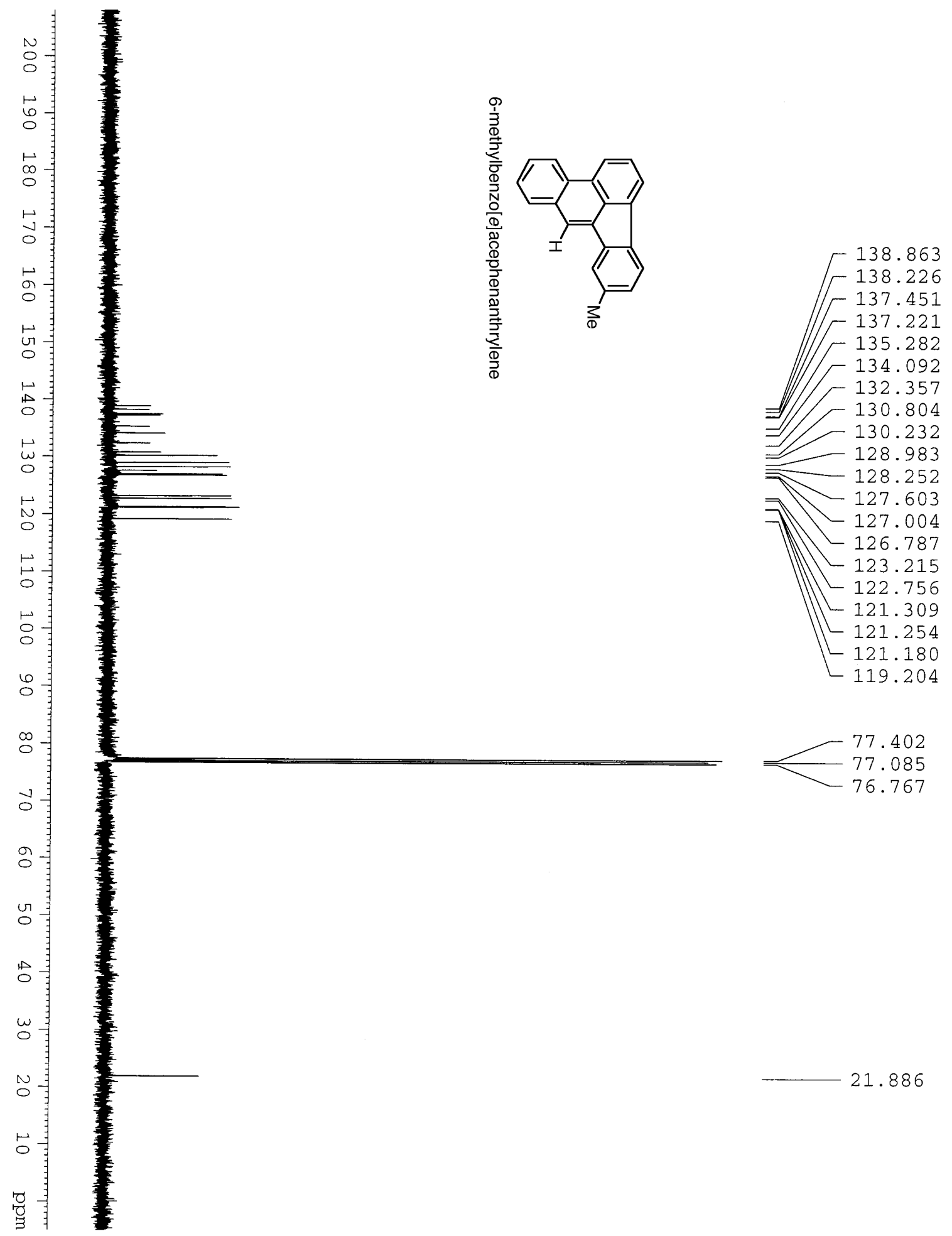


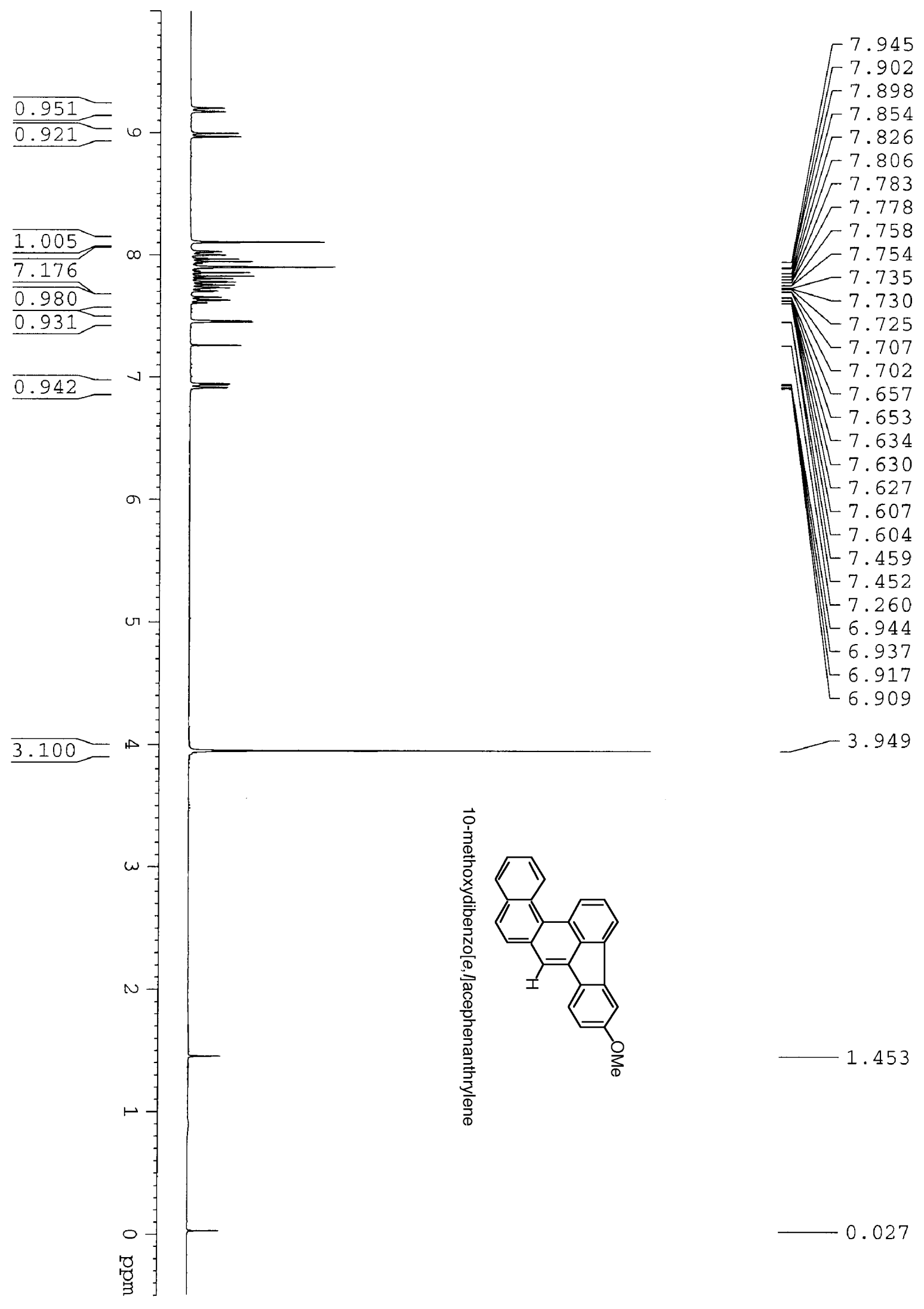




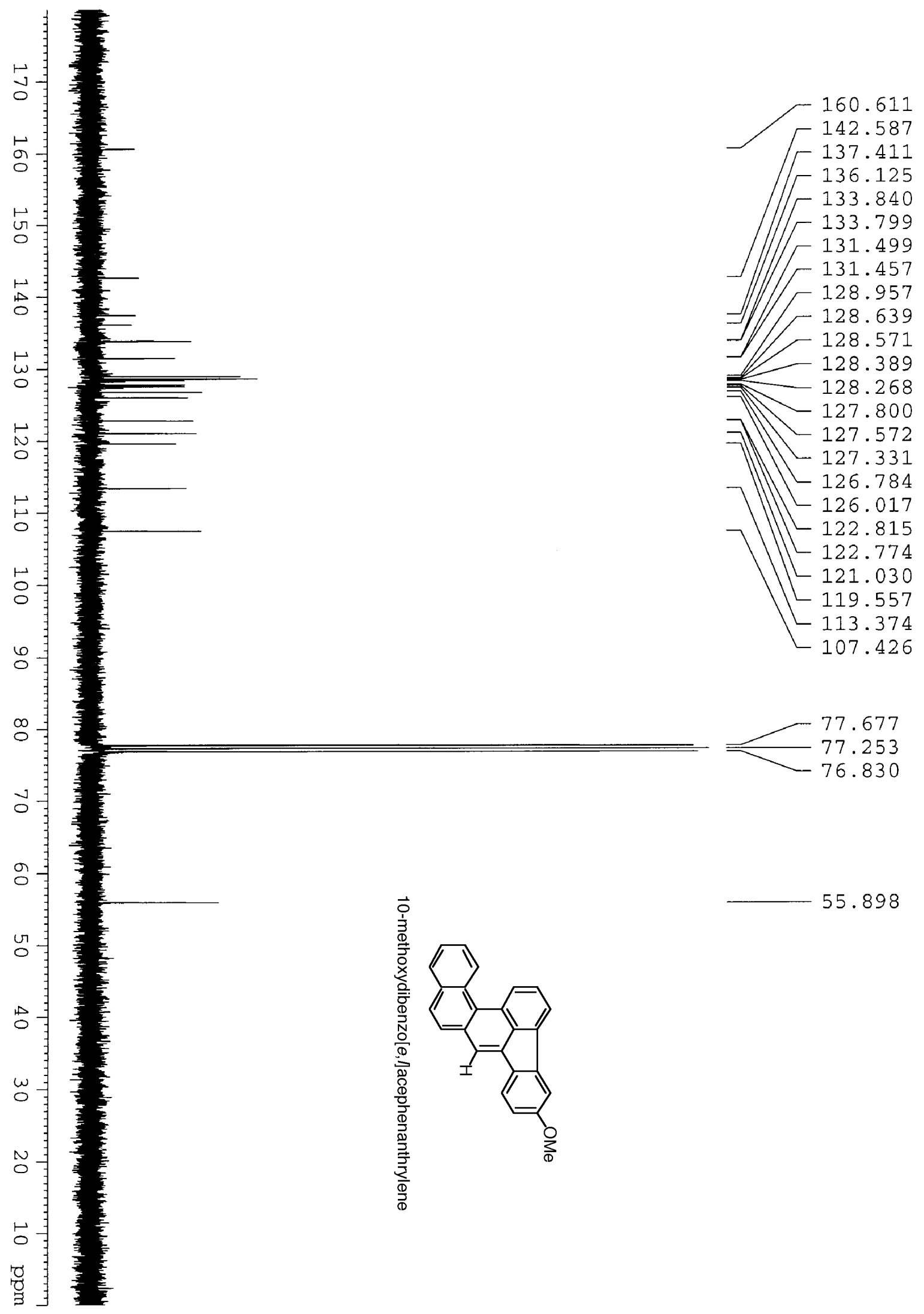




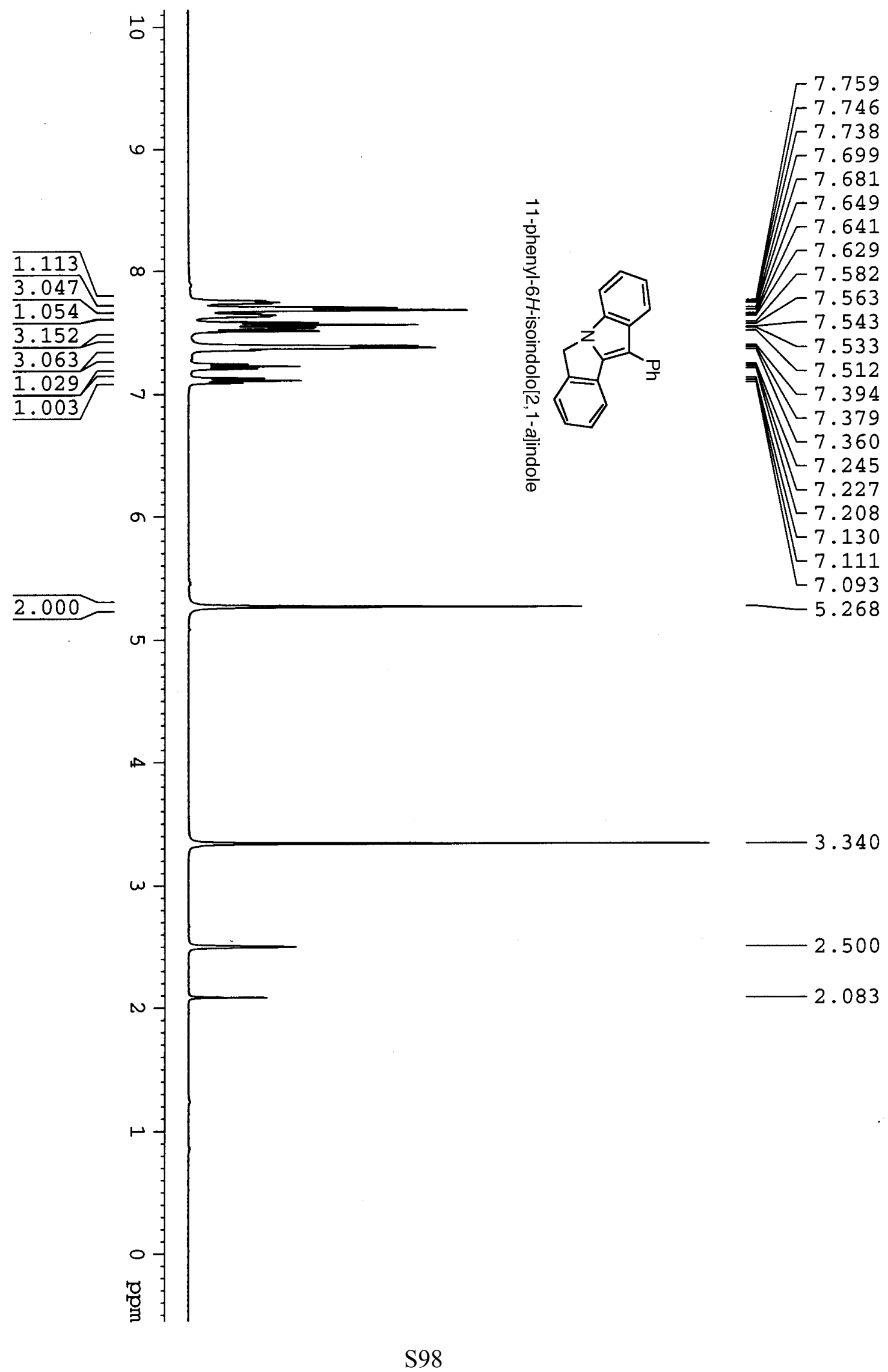




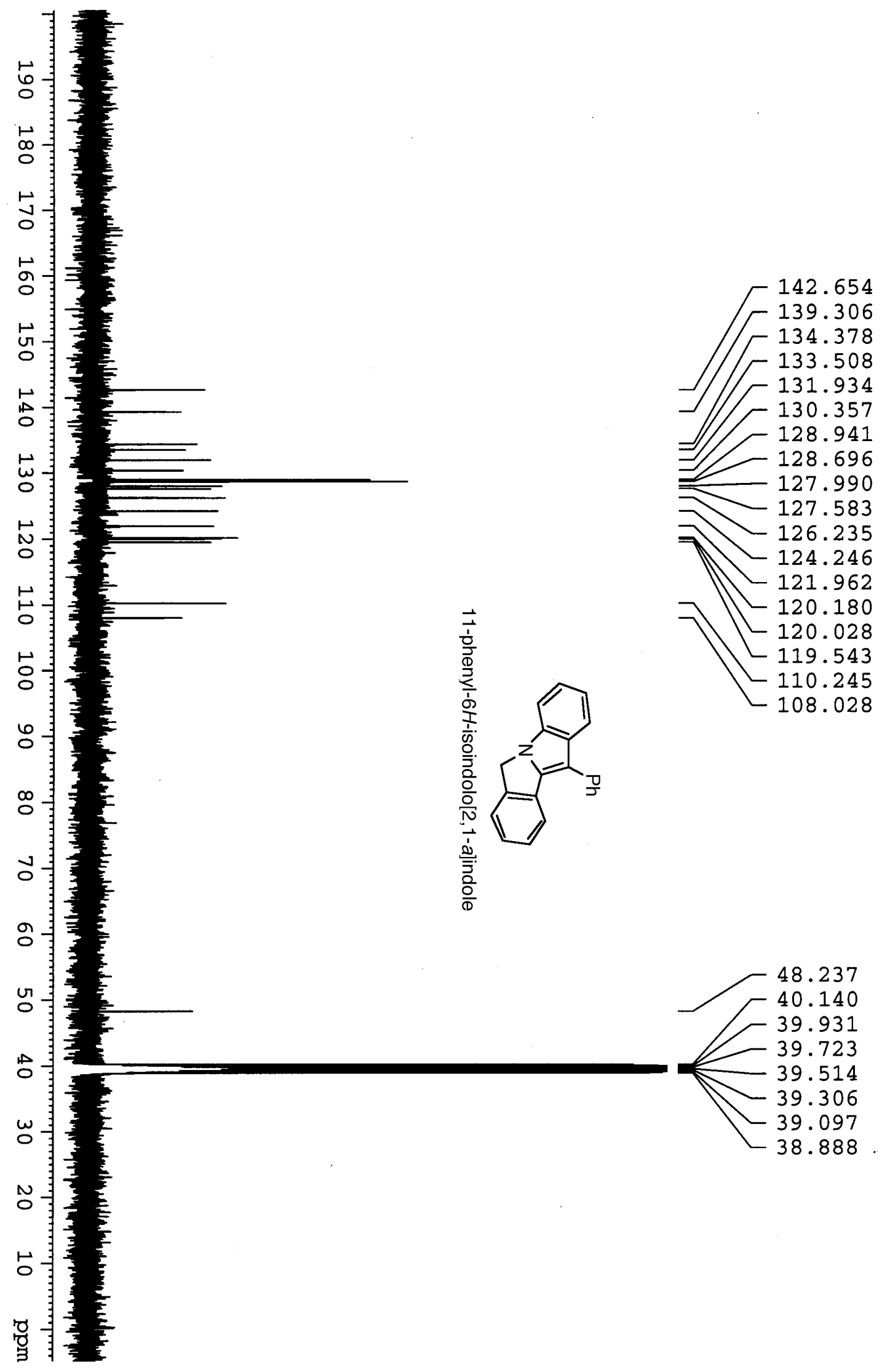




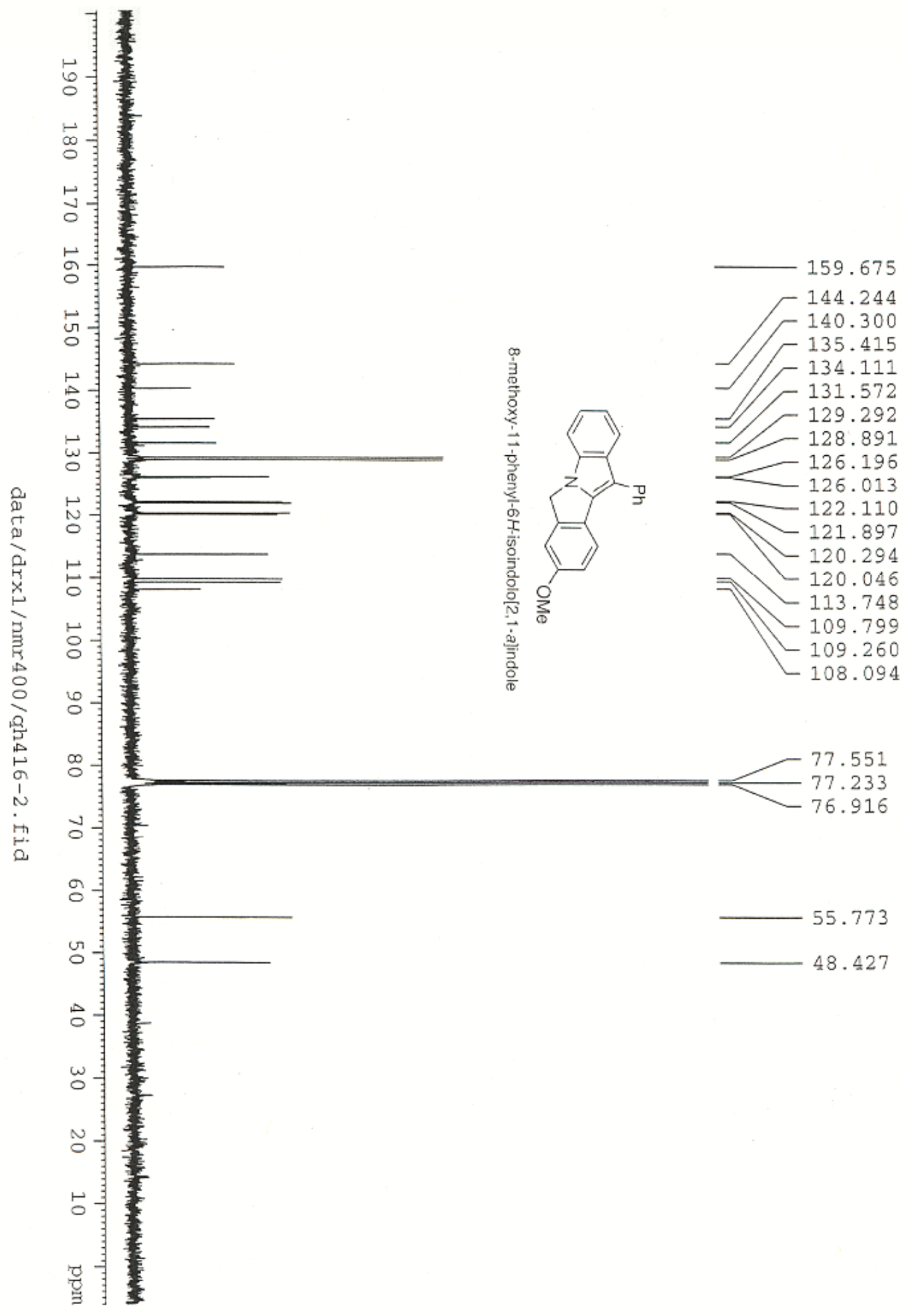




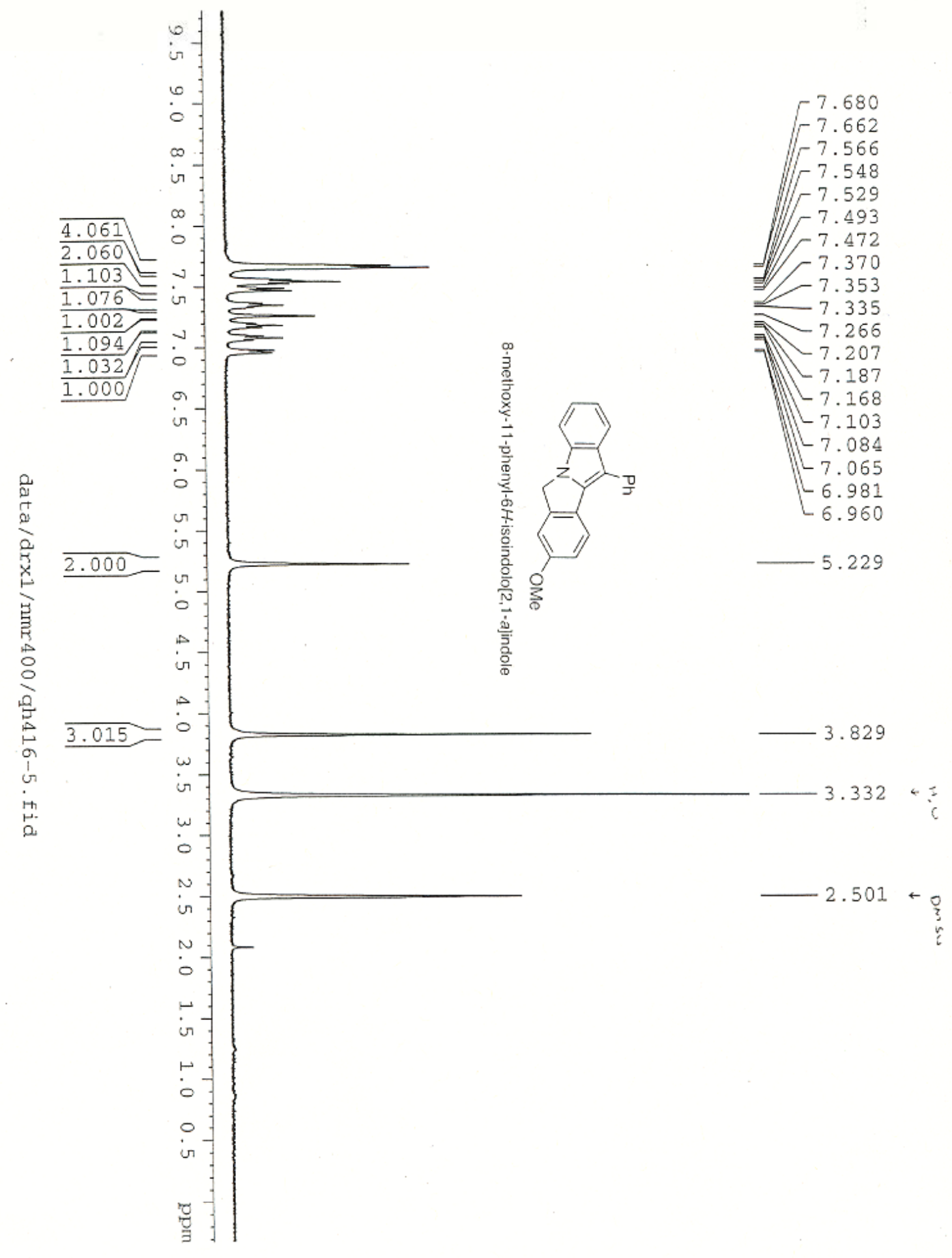




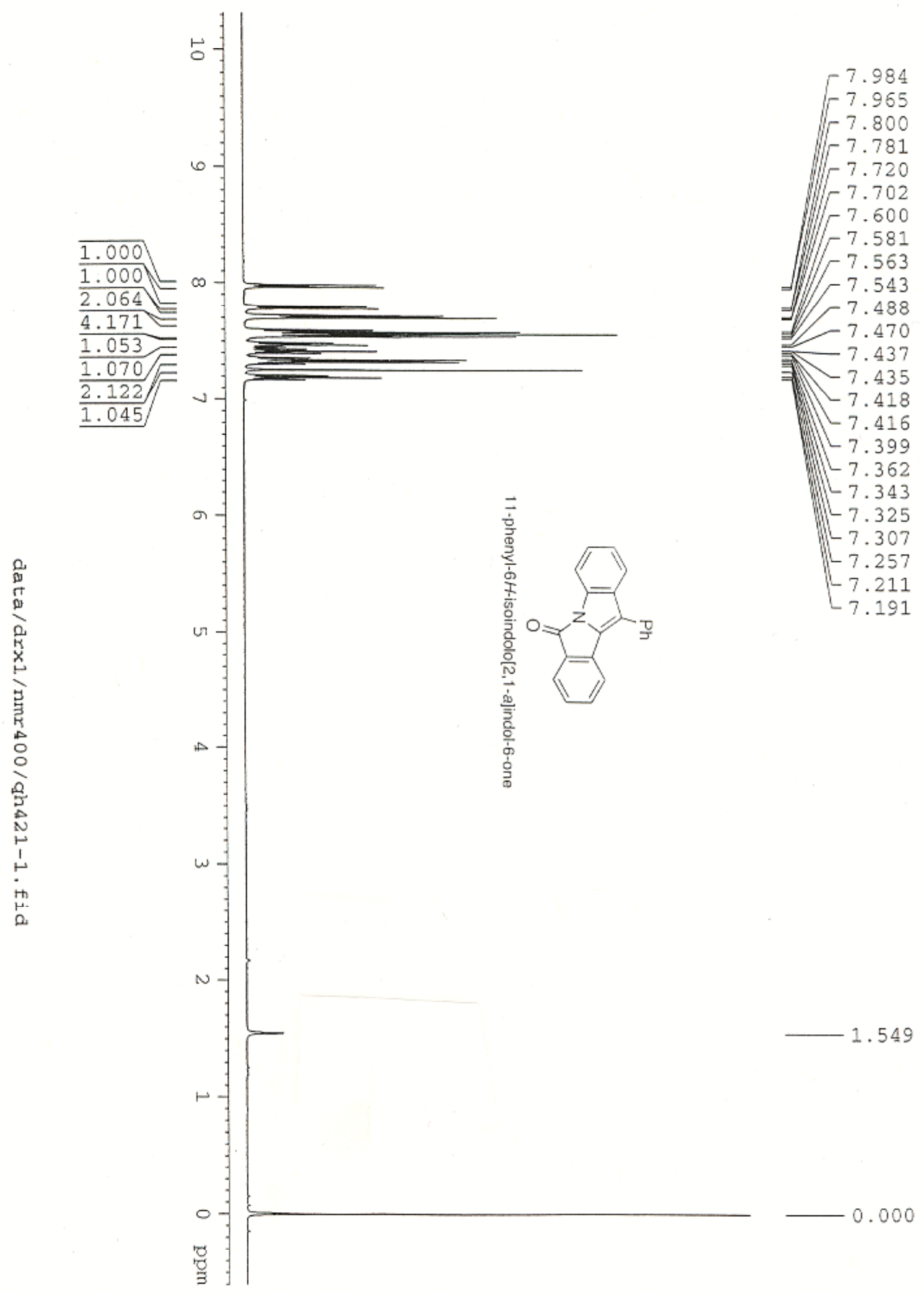




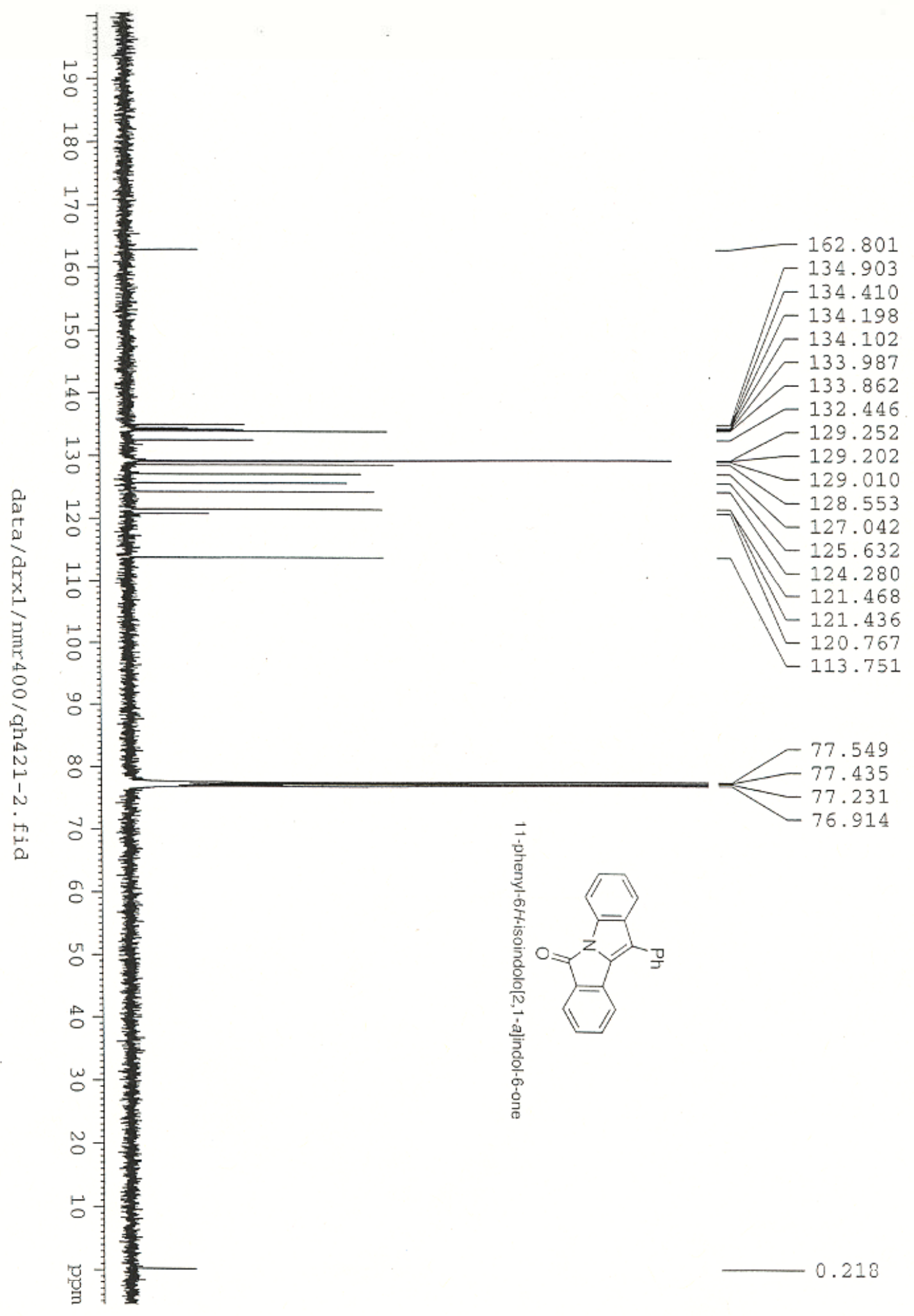




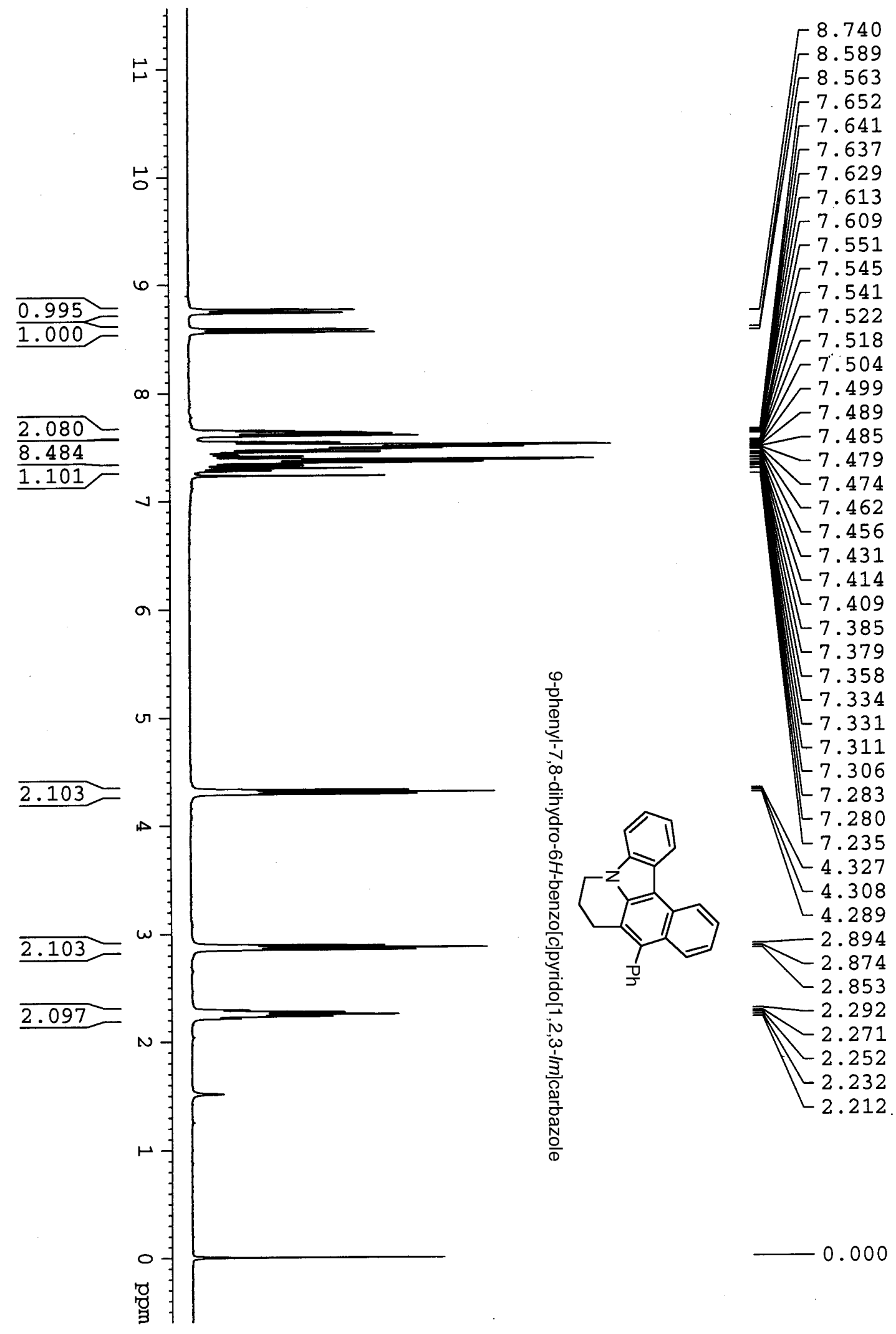




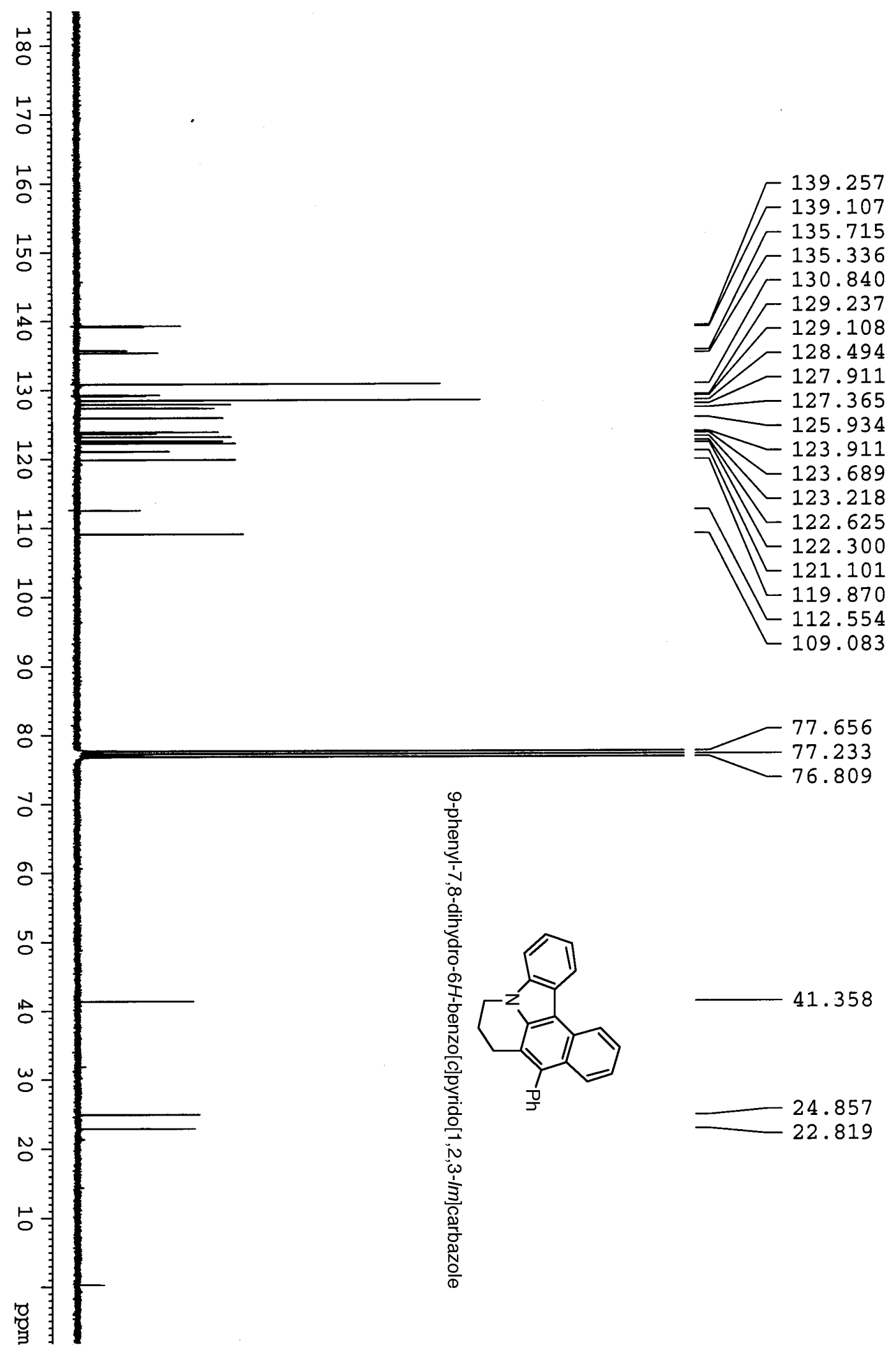




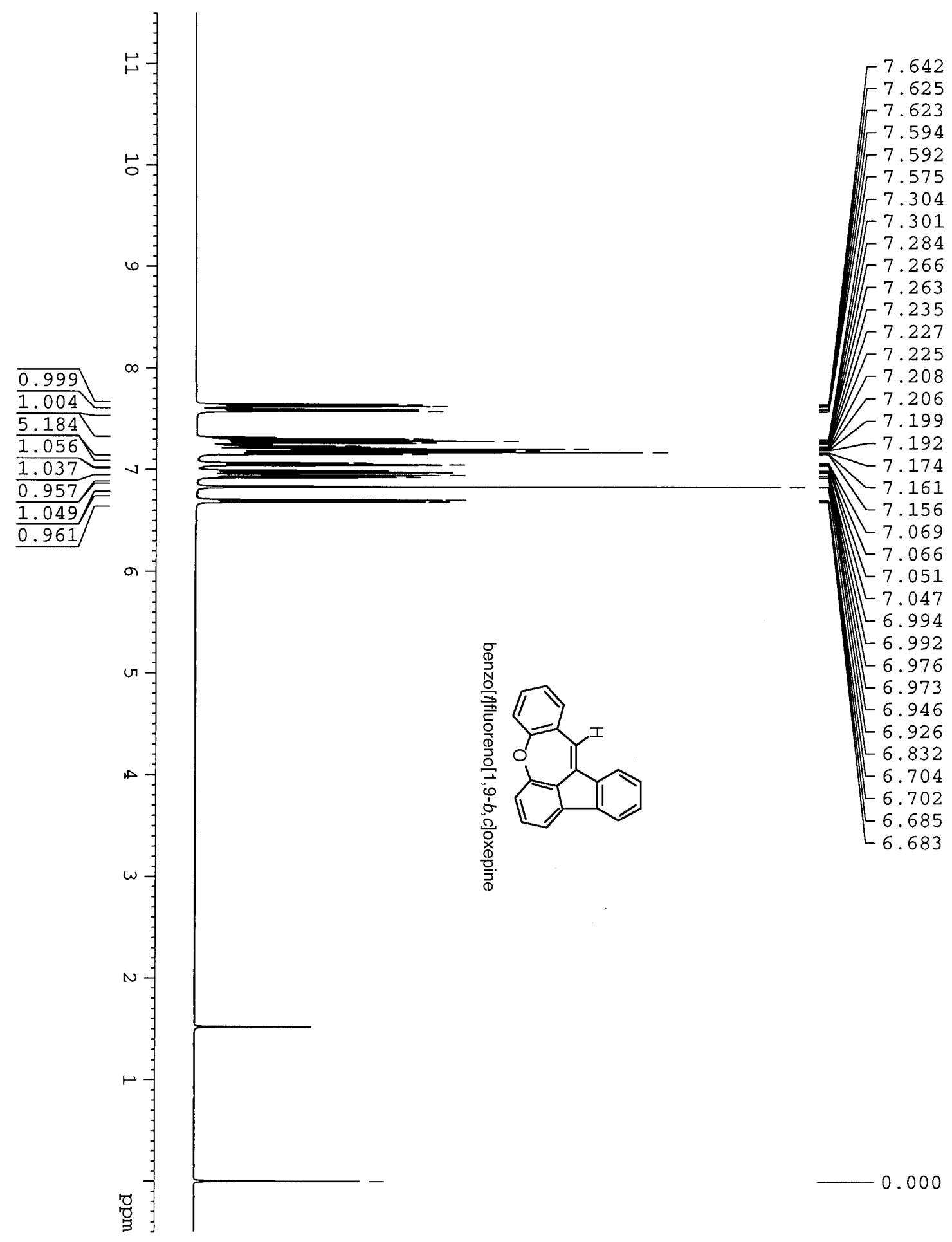




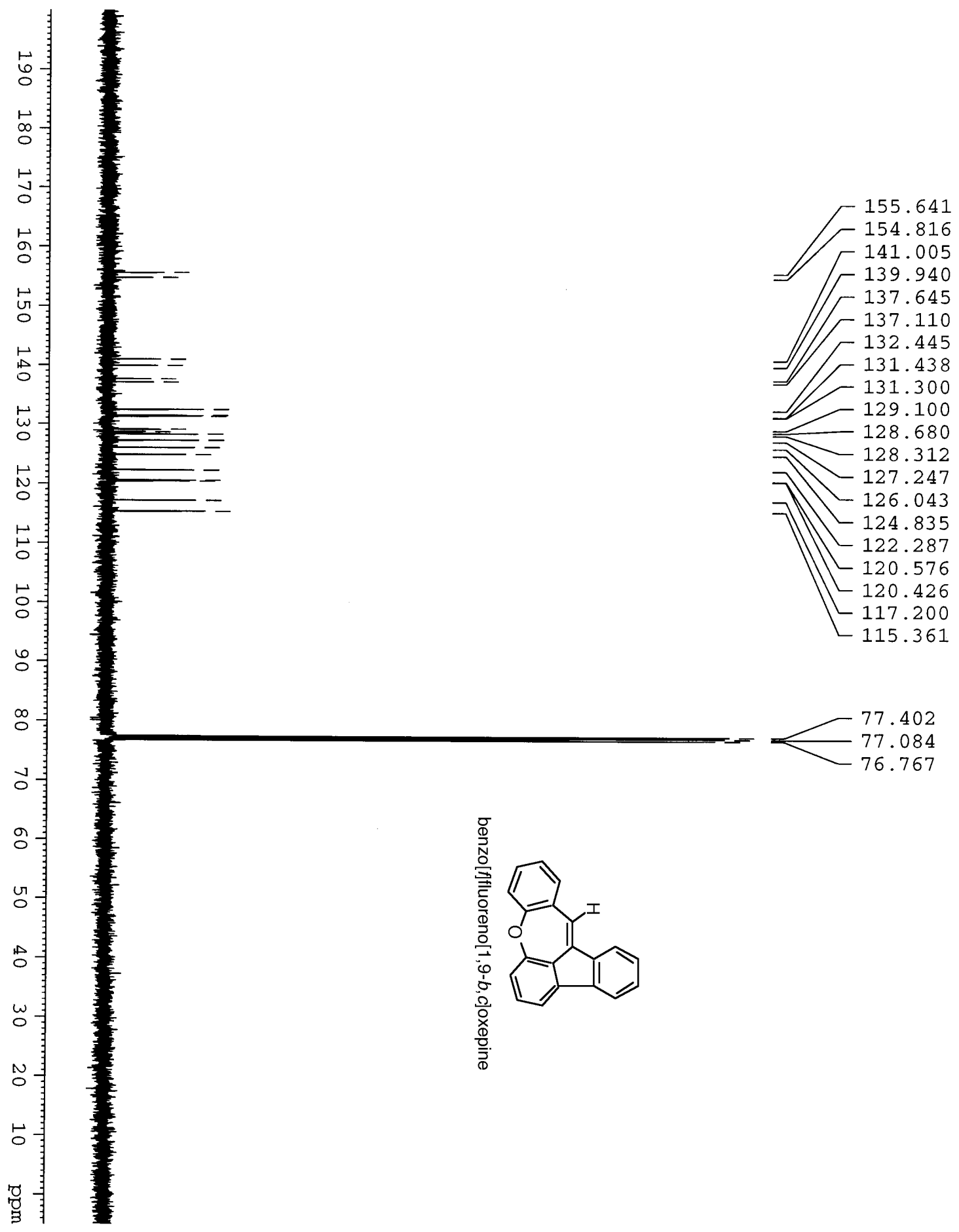

